CRYSTALLOGRAPHIC COMMUNICATIONS

ISSN 2056-9890

Received 13 March 2019

Accepted 22 May 2019

Edited by M. Weil, Vienna University of Technology, Austria

Keywords: crystal structure; crystal field stabilization; pyridine dicarboxylic acids; polydentate ligands; coordination polymers; $\mathrm{Ni}$ "l complexes; Zn" complexes.

CCDC references: $1917869 ; 1917868$; $1917867 ; 1917866 ; 1917865 ; 1917864$

Supporting information: this article has supporting information at journals.iucr.org/e

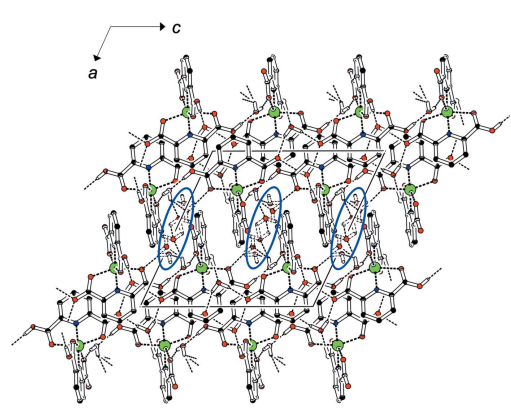

OPEN $\odot$ ACCESS

\section{Zn and Ni complexes of pyridine-2,6-dicarboxyl- ates: crystal field stabilization matters!}

\author{
Marius Kremer and Ulli Englert*
}

Institut für Anorganische Chemie, RWTH Aachen University, Landoltweg 1, 52074 Aachen, Germany. *Correspondence e-mail: ullrich.englert@ac.rwth-aachen.de

Six reaction products of $\mathrm{Zn}^{\mathrm{II}}$ and $\mathrm{Ni}^{\mathrm{II}}$ with pyridine-2,6-dicarboxylic acid $\left(\mathrm{H}_{2} \mathrm{Lig}^{1}\right)$, 4-chloropyridine-2,6-dicarboxylic acid $\left(\mathrm{H}_{2} \mathrm{Lig}^{2}\right)$ and 4-hydroxypyridine-2,6-dicarboxylic acid $\left(\mathrm{H}_{2} \mathrm{Lig}^{3}\right)$ are used to pinpoint the structural consequences of crystal field stabilization by an incomplete $d$ shell. The pseudooctahedral $\mathrm{Zn}^{\mathrm{II}}$ coordination sphere in bis(6-carboxypicolinato)zinc(II) trihydrate, $\left[\mathrm{Zn}\left(\mathrm{C}_{7} \mathrm{H}_{4} \mathrm{NO}_{4}\right)_{2}\right] \cdot 3 \mathrm{H}_{2} \mathrm{O}$ or $\left[\mathrm{Zn}\left(\mathrm{HLig}^{1}\right)_{2}\right] \cdot 3 \mathrm{H}_{2} \mathrm{O},(\mathbf{1})$, is significantly less regular than that about $\mathrm{Ni}^{\mathrm{II}}$ in the isostructural compound bis(6-carboxypicolinato)nickel(II) trihydrate, $\left[\mathrm{Ni}\left(\mathrm{C}_{7} \mathrm{H}_{4} \mathrm{NO}_{4}\right)_{2}\right] \cdot 3 \mathrm{H}_{2} \mathrm{O}$ or $\left[\mathrm{Ni}\left(\mathrm{HLig}^{1}\right)_{2}\right] \cdot 3 \mathrm{H}_{2} \mathrm{O}$, (2). The $\mathrm{Zn}^{\mathrm{II}}$ complexes poly[(4-chloropyridine-2,6-dicarboxylato)zinc(II)], $\left[\mathrm{Zn}\left(\mathrm{C}_{7} \mathrm{H}_{2} \mathrm{ClNO}_{4}\right)\right]_{n}$ or $\left[\mathrm{Zn}\left(\mathrm{Lig}^{2}\right)\right]_{n},(3)$, and poly[[(4-hydroxypyridine-2,6-dicarboxylato)zinc(II)] monohydrate], $\left\{\left[\mathrm{Zn}\left(\mathrm{C}_{7} \mathrm{H}_{3} \mathrm{NO}_{5}\right)\right] \cdot \mathrm{H}_{2} \mathrm{O}\right\}_{n}$ or $\left\{\left[\mathrm{Zn}\left(\mathrm{Lig}^{3}\right)\right] \cdot-\right.$ $\left.\mathrm{H}_{2} \mathrm{O}\right\}_{n}$, (4), represent two-dimensional coordination polymers with chelating and bridging pyridine-2,6-dicarboxylate ligands in which the coordination polyhedra about the central cations cannot be associated with any regular shape; their coordination environments range between trigonal-bipyramidal and square-pyramidal geometries. In contrast, the corresponding adducts of the diprotonated ligands to $\mathrm{Ni}^{\mathrm{II}}$, namely triaqua(4-chloropyridine-2,6-dicarboxylato)nickel(II), $\left[\mathrm{Ni}\left(\mathrm{C}_{7} \mathrm{H}_{2} \mathrm{ClNO}_{4}\right)\left(\mathrm{H}_{2} \mathrm{O}\right)_{3}\right]$ or $\left.\left[\mathrm{NiLig}^{2}\left(\mathrm{OH}_{2}\right)_{3}\right)\right],(5)$, and triaqua(4hydroxypyridine-2,6-dicarboxylato)nickel(II) 1.7-hydrate, $\left[\mathrm{Ni}\left(\mathrm{C}_{7} \mathrm{H}_{3} \mathrm{NO}_{5}\right)\right.$ $\left.\left(\mathrm{H}_{2} \mathrm{O}\right)_{3}\right] \cdot 1.7 \mathrm{H}_{2} \mathrm{O}$ or $\left.\left[\mathrm{NiLig}^{3}\left(\mathrm{OH}_{2}\right)_{3}\right)\right] \cdot 1.7 \mathrm{H}_{2} \mathrm{O},(6)$, feature rather regular octahedral coordination spheres about the transition-metal cations, thus precluding the formation of analogous extended structures.

\section{Chemical context}

Pyridine-2,6-dicarboxylic acid $\left(\mathrm{H}_{2} \mathrm{Lig}^{1}\right.$, Fig. 1) represents a popular building block in coordination chemistry: the Cambridge Structural Database (CSD; Groom et al., 2016) comprises 1404 structurally characterized metal complexes of this ligand. Its 4-chloro $\left(\mathrm{H}_{2} \mathrm{Lig}^{2}\right)$ and 4-hydroxy $\left(\mathrm{H}_{2} \mathrm{Lig}^{3}\right)$ derivatives have been employed less frequently, with only 10 and 136 entries, respectively, in the CSD. We have investigated these three pyridine-2,6-dicarboxylic acids, $\mathrm{Lig}^{1}-\mathrm{Lig}^{3}$, in a comprehensive study of their complexes with $\mathrm{Ni}^{\mathrm{II}}$ and $\mathrm{Zn}^{\mathrm{II}}$. We focus on these cations for the following reasons: (a) According to the widely used compilation of Shannon (1976), $\mathrm{Ni}^{\mathrm{II}}$ and $\mathrm{Zn}^{\mathrm{II}}$ adopt comparable ionic radii of 0.69 and $0.74 \AA$, respectively, in their six-coordinated complexes. Alternative divalent cations might be $\mathrm{Mn}^{\mathrm{II}}$ and $\mathrm{Cu}^{\mathrm{II}}$; the former is associated with a significantly larger ionic radius, the latter is notoriously Jahn-Teller distorted. (b) For $\mathrm{Ni}^{\mathrm{II}}$ and $\mathrm{Zn}^{\mathrm{II}}$, undistorted octahedral complexes can, in principle, be expected. Crystal field stabilization energy for $\mathrm{Ni}^{\mathrm{II}}$ results in a clear preference for regular coordination, with the fully occupied $t_{2 g}$ orbitals directed in-between and the only half- 


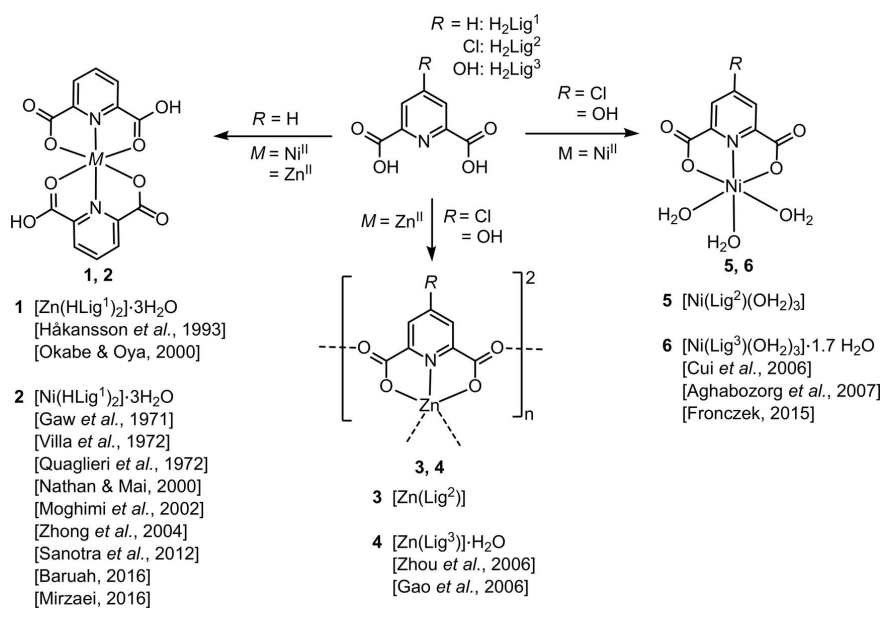

Figure 1

Compilation of the structural characterizations performed in the context of this work and of previous literature. References: 1: Håkansson et al. (1993); Okabe \& Oya (2000); 2: Gaw et al. (1971); Villa et al. (1972); Quaglieri et al. (1972); Nathan \& Mai (2000); Moghimi et al. (2002); Zhong et al. (2004); Sanotra et al. (2012); Baruah (2016); Mirzaei (2016); 4: Zhou et al. (2006); Gao et al. (2006); 6: Cui et al. (2006); Aghabozorg et al. (2007); Fronczek (2015).

occupied $e_{g}$ orbitals towards the octahedrally disposed ligands. No such electronic effects are expected for the $d^{10}$-configured $\mathrm{Zn}^{\mathrm{II}}$ ion: in this case, a regular coordination is neither preferred nor excluded. We use our structural results on the $\mathrm{Ni}^{\mathrm{II}}$ and $\mathrm{Zn}^{\mathrm{II}}$ derivatives compiled in Fig. 1 to pinpoint the different coordination behaviour of these divalent cations; Fig. 1 also reports previous results by other authors that have been obtained for the same compounds and, to the best of our knowledge, have never been put into a common context.
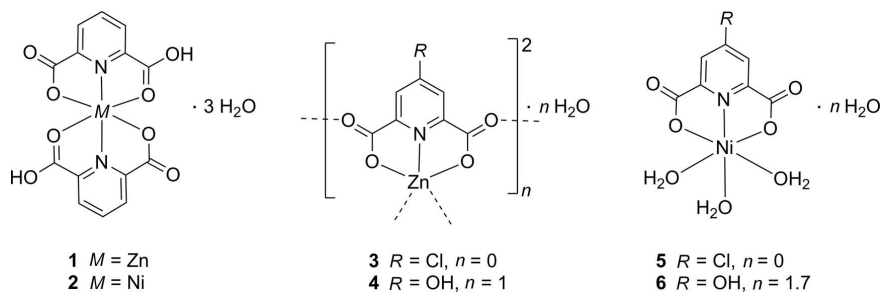

$5 \mathrm{R}=\mathrm{Cl}, n=0$ $6 \mathrm{R}=\mathrm{OH}, n=1.7$

\section{Structural comparison}

\section{Mononuclear bis(6-carboxypicolinato) complexes}

We start our comparison between $\mathrm{Ni}^{\mathrm{II}}$ and $\mathrm{Zn}^{\mathrm{II}}$ coordination with their mononuclear complexes with two equivalents of monodeprotonated $\mathrm{Lig}^{1}$. The resulting products $\mathbf{1}$ and $\mathbf{2}$ have previously been structurally characterized and are isostructural. Their asymmetric unit contains a complex molecule and three molecules of water; one of the latter is disordered over three neighbouring and mutually exclusive positions. The previous studies of 1 (Håkansson et al., 1993; Okabe \& Oya, 2000) agree with our structural model as far as the $\operatorname{bis}\left(\mathrm{Hlig}^{1}\right)$ complex is concerned, but the three water molecules were treated as ordered; both studies find an equivalent displacement parameter of $0.28 \AA^{2}$ for one of the
Table 1

Selected geometric parameters $\left(\AA,^{\circ}\right)$ for $\mathbf{1}$.

\begin{tabular}{lrlr}
\hline $\mathrm{Zn} 1-\mathrm{N} 2$ & $2.0102(15)$ & $\mathrm{Zn} 1-\mathrm{O} 5$ & $2.1245(15)$ \\
$\mathrm{Zn} 1-\mathrm{N} 1$ & $2.0155(15)$ & $\mathrm{Zn} 1-\mathrm{O} 7$ & $2.3093(15)$ \\
$\mathrm{Zn} 1-\mathrm{O} 1$ & $2.0833(14)$ & $\mathrm{Zn} 1-\mathrm{O} 3$ & $2.3312(14)$ \\
& & & \\
$\mathrm{N} 2-\mathrm{Zn} 1-\mathrm{N} 1$ & $167.53(6)$ & $\mathrm{O} 1-\mathrm{Zn} 1-\mathrm{O} 7$ & $94.21(6)$ \\
$\mathrm{N} 2-\mathrm{Zn} 1-\mathrm{O} 1$ & $113.04(6)$ & $\mathrm{O}-\mathrm{Zn} 1-\mathrm{O} 7$ & $152.42(6)$ \\
$\mathrm{N} 1-\mathrm{Zn} 1-\mathrm{O} 1$ & $79.13(6)$ & $\mathrm{N} 2-\mathrm{Zn} 1-\mathrm{O} 3$ & $94.15(6)$ \\
$\mathrm{N} 2-\mathrm{Zn} 1-\mathrm{O} 5$ & $78.25(6)$ & $\mathrm{N} 1-\mathrm{Zn} 1-\mathrm{O} 3$ & $73.57(5)$ \\
$\mathrm{N} 1-\mathrm{Zn} 1-\mathrm{O} 5$ & $103.77(6)$ & $\mathrm{O} 1-\mathrm{Zn} 1-\mathrm{O} 3$ & $152.62(5)$ \\
$\mathrm{O} 1-\mathrm{Zn} 1-\mathrm{O} 5$ & $96.75(6)$ & $\mathrm{O} 5-\mathrm{Zn} 1-\mathrm{O} 3$ & $91.74(6)$ \\
$\mathrm{N} 2-\mathrm{Zn} 1-\mathrm{O} 7$ & $74.17(6)$ & $\mathrm{O} 7-\mathrm{Zn} 1-\mathrm{O} 3$ & $90.01(5)$ \\
$\mathrm{N} 1-\mathrm{Zn} 1-\mathrm{O} 7$ & $103.12(5)$ & & \\
\hline
\end{tabular}

water sites, clearly excessive when compared to all other displacement parameters in the structure. A displacement ellipsoid plot of the $\left[\mathrm{Zn}\left(\mathrm{HLig}^{1}\right)_{2}\right]$ complex is shown in Fig. 2.

The three ligand functionalities differ significantly in their bond lengths to the six-coordinated metal cation (Table 1): the shortest bonds are subtended by the pyridine $\mathrm{N}$ atoms, followed by the distances between $\mathrm{Zn}^{\mathrm{II}}$ and an oxygen atom of the deprotonated carboxylato groups. The $\mathrm{O}$ atoms of the carboxylic acid moieties represent the most distant coordination partners. Our assignment of negatively charged carboxylato and neutral carboxylic acid moieties matches the assignment of local electron-density maxima close to the latter; the positional parameters for the thus located $\mathrm{H}$ atoms could be freely refined. Each of these hydroxy $\mathrm{H}$ atoms is engaged in a short hydrogen bond to one of the well-ordered water molecules. Our structure model for compound $\mathbf{2}$ is very similar to that for the isostructural 1; distances and angles are compiled in Table 2. Those references to previous reports of the crystal structure of $\mathbf{2}$ that agree with our interpretation are compiled in Fig. 1. We here also mention two dissenting

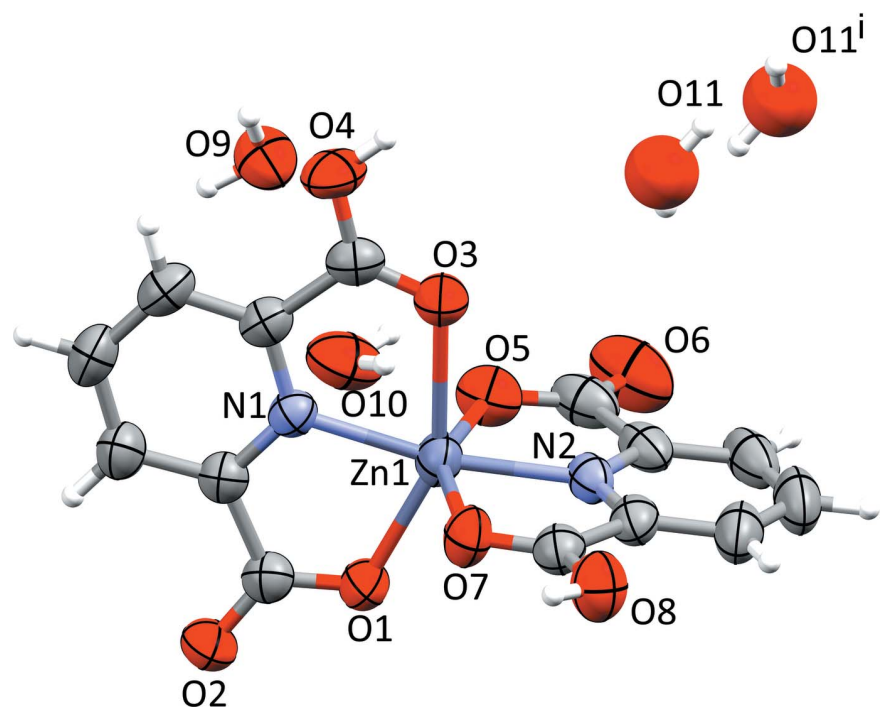

Figure 2

Displacement ellipsoid plot (Macrae et al., 2006) of the asymmetric unit of 1. Sites of minor occupancy for O11 have been omitted. Displacement ellipsoids are drawn at the $70 \%$ probability level and $\mathrm{H}$ atoms are shown as spheres of arbitrary radii. 
Table 2

Selected geometric parameters $\left(\AA,^{\circ}\right)$ for $\mathbf{2}$.

\begin{tabular}{lrlr}
\hline Ni1-N1 & $1.9654(15)$ & Ni1-O5 & $2.1036(14)$ \\
Ni1-N2 & $1.9720(16)$ & Ni1-O3 & $2.1666(14)$ \\
Ni1-O1 & $2.0959(14)$ & Ni1-O7 & $2.1940(14)$ \\
& & & \\
N1-Ni1-N2 & $176.53(6)$ & O1-Ni1-O3 & $156.09(6)$ \\
N1-Ni1-O1 & $78.84(6)$ & O5-Ni1-O3 & $92.85(6)$ \\
N2-Ni1-O1 & $104.49(6)$ & N1-Ni1-O7 & $104.37(6)$ \\
N1-Ni1-O5 & $100.48(6)$ & N2-Ni1-O7 & $76.60(6)$ \\
N2-Ni1-O5 & $78.52(6)$ & O1-Ni1-O7 & $93.18(6)$ \\
O1-Ni1-O5 & $92.69(6)$ & O5-Ni1-O7 & $155.12(6)$ \\
N1-Ni1-O3 & $77.29(6)$ & O3-Ni1-O7 & $91.51(6)$ \\
N2-Ni1-O3 & $99.40(6)$ & &
\end{tabular}

opinions: Wang et al. (2004) indexed their diffraction patterns with the same unit cell as we used but interpreted the electron density as $\left[\mathrm{Ni}\left(\mathrm{Lig}^{1}\right)_{2}\right] \cdot 2 \mathrm{H}_{3} \mathrm{O} \cdot 2 \mathrm{H}_{2} \mathrm{O}$, i.e. as the bis(oxonium) salt of a dianionic nickelate. We doubt this protonation pattern, not only because of the alleged presence of strongly acidic oxonium ions next to carboxylate but also because this alternative structure model comes with short inter-oxygen contacts of $c a 2.5 \AA$ without any proton in between. A rather recent compilation of related structures (Mirzaei et al., 2014) refers to 2 as $\left[\mathrm{Ni}\left(\mathrm{HLig}^{1}\right)_{2}\right] \cdot \mathrm{H}_{3} \mathrm{O} \cdot 2 \mathrm{H}_{2} \mathrm{O}$, without further explanation concerning the unbalanced charge; the reported unit cell corresponds to that found by us and all consenting authors in Fig. 1.

After discussing the individual bis-ligand complexes $\mathbf{1}$ and 2, we come back to the principal aim of our comparison: despite the strict isotypism between these structures, which even extends to the disorder in the co-crystallized water molecules, the coordination spheres about $\mathrm{Zn}^{\mathrm{II}}$ in $\mathbf{1}$ and $\mathrm{Ni}^{\mathrm{II}}$ in $\mathbf{2}$ differ significantly. The numerical values of bond lengths and angles compiled in Tables 1 and 2 reflect a more regular coordination polyhedron for the crystal-field-stabilized nickel ion. According to classical crystal field theory, the pseudooctahedrally arranged coordinating $\mathrm{N}$ and $\mathrm{O}$ atoms avoid the electron density associated with the fully occupied $t_{2 g}$ orbitals

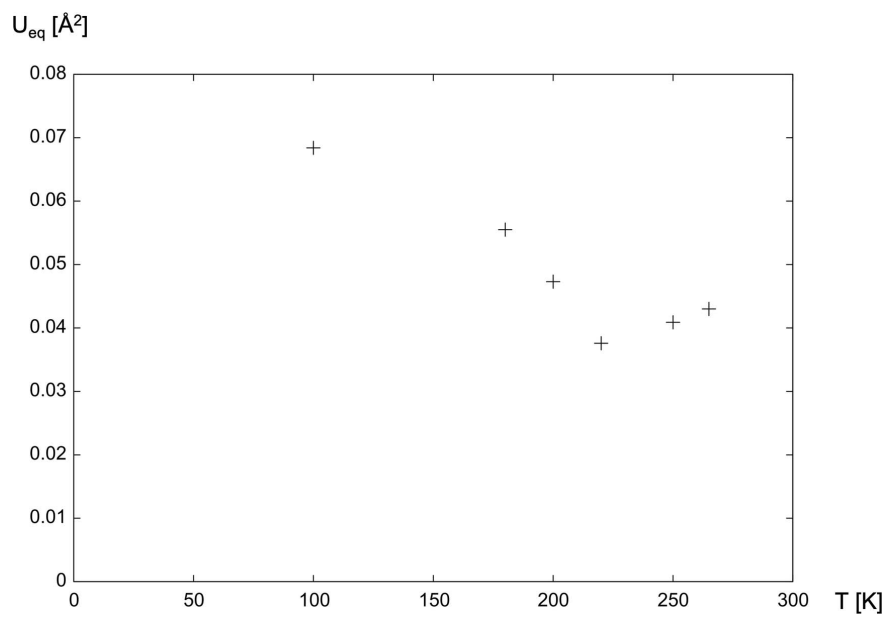

Figure 3

Average $U_{\text {eq }}$ values for the atoms in the $\left[\mathrm{Zn}\left(\mathrm{HLig}^{1}\right)_{2}\right]$ complex molecule as a function of temperature; $U_{\text {eq }}$ values for the $\mathrm{O}$ atoms in the cocrystallized water molecules were not taken into account.

in the nickel cation with electron configuration $d^{8}$. No such effect is observed for the significantly more distorted coordination about the $d^{10}$-configured $\mathrm{Zn}^{\mathrm{II}}$.

We finish the discussion of $\mathbf{1}$ and $\mathbf{2}$ by explaining our datacollection temperatures: Upon cooling to low temperature, complexes $\mathbf{1}$ and $\mathbf{2}$ undergo a reversible phase transition to a larger unit cell. Despite several attempts at different temperatures and cooling rates, we have not been able to completely index the low-temperature diffraction pattern, neither assuming single crystals nor twins. The most promising indexing attempt suggested a non-centrosymmetric bodycentered unit cell with four independent complex molecules in the asymmetric unit. Such a low-temperature phase cannot be traced back to a single $t$ or $k$ type phase transition; rather, it requires a combination of both (Müller, 2013). In view of the incompletely indexed diffraction pattern, the observed twinning and the large asymmetric unit after the phase transition, we have not been able to deduce a fully satisfactory structural model for the low-temperature phase. In order to establish the transition temperature, we have collected intensity data for $\mathbf{1}$ as a function of temperature. The temperature dependence of the average $U_{\text {eq }}$ values for the atoms in the complex molecule is depicted in Fig. 3.

Based on this relationship and on the fact that it could be satisfactorily indexed, we decided to use the intensity data set collected at $220 \mathrm{~K}$ for the structure refinement of $\mathbf{1}$. Only data collected at room temperature, at $250 \mathrm{~K}$ and a tentative data set at $100 \mathrm{~K}$ were available for $\mathbf{2}$; our structure refinement is based on the $250 \mathrm{~K}$ data.

Extended coordination networks of 4-substituted dicarboxylato pyridine ligands with $\mathrm{Zn}^{\text {II }}$

The reaction products of $\mathrm{ZnCl}_{2}$ with $\mathrm{H}_{2} \mathrm{Lig}^{2}$ and $\mathrm{H}_{2} \mathrm{Lig}^{3}$ in aqueous solution are isostructural and represent two-dimensional extended structures extending parallel to (001). The asymmetric unit of $\mathbf{3}$ contains a single formula unit of $\mathrm{Zn}\left(\mathrm{Lig}^{2}\right)$ and is depicted in Fig. 4a; for easier comparison, an analogous representation for the closely related compound $\mathbf{4}$ is shown in Fig. $4 b$.

One might intuitively associate the coordination about the $\mathrm{Zn}^{\mathrm{II}}$ cation with a trigonal bipyramid, with $\mathrm{O} 1$ and $\mathrm{O} 3$ as the axial substituents, but the angle $\mathrm{O} 2{ }^{\mathrm{i}}-\mathrm{Zn} 1-\mathrm{N} 1$ [symmetry code: (i) $y, 2-x, 1-z$ ] also amounts to a relatively large

(a)

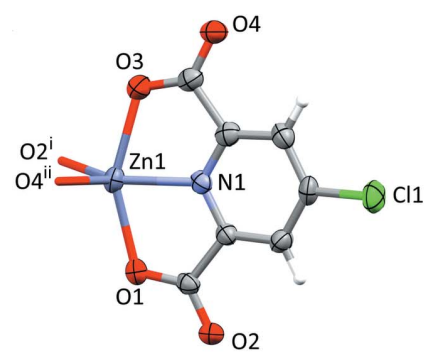

Figure 4

Displacement ellipsoid plots (90\% probability, (Macrae et al., 2006)) of the extended asymmetric unit for $(a) 3$ and $(b) \mathbf{4} ; \mathrm{H}$ atoms are shown as spheres of arbitrary radii. Symmetry codes: (i) $y, 2-x, 1-z$; (ii) $y, 1-x$, $1-z$. 
Table 3

Selected geometric parameters $\left(\AA,^{\circ}\right)$ for $\mathbf{3}$.

\begin{tabular}{lllr}
\hline $\mathrm{Zn} 1-\mathrm{O} 2^{\mathrm{i}}$ & $1.950(2)$ & $\mathrm{Zn} 1-\mathrm{O} 1$ & $2.178(2)$ \\
$\mathrm{Zn} 1-\mathrm{O} 4^{\mathrm{ii}}$ & $1.985(2)$ & $\mathrm{Zn} 1-\mathrm{O} 3$ & $2.214(2)$ \\
$\mathrm{Zn} 1-\mathrm{N} 1$ & $2.034(2)$ & & \\
& & & \\
$\mathrm{O}^{\mathrm{i}}-\mathrm{Zn} 1-\mathrm{O} 4^{\mathrm{ii}}$ & $101.71(8)$ & $\mathrm{N} 1-\mathrm{Zn} 1-\mathrm{O} 1$ & $76.44(9)$ \\
$\mathrm{O}^{\mathrm{i}}-\mathrm{Zn} 1-\mathrm{N} 1$ & $139.20(10)$ & $\mathrm{O} 2^{\mathrm{i}}-\mathrm{Zn} 1-\mathrm{O} 3$ & $93.68(9)$ \\
$\mathrm{O} 4^{\mathrm{ii}}-\mathrm{Zn} 1-\mathrm{N} 1$ & $117.79(9)$ & $\mathrm{O} 4^{\mathrm{ii}}-\mathrm{Zn} 1-\mathrm{O} 3$ & $93.58(9)$ \\
$\mathrm{O} 2^{\mathrm{i}}-\mathrm{Zn} 1-\mathrm{O} 1$ & $105.86(9)$ & $\mathrm{N} 1-\mathrm{Zn} 1-\mathrm{O} 3$ & $75.04(9)$ \\
$\mathrm{O} 4^{\mathrm{ii}}-\mathrm{Zn} 1-\mathrm{O} 1$ & $102.54(9)$ & $\mathrm{O} 1-\mathrm{Zn} 1-\mathrm{O} 3$ & $151.30(7)$ \\
\hline
\end{tabular}

Symmetry codes: (i) $y,-x+2,-z+1$; (ii) $y,-x+1,-z+1$.

Table 4

Selected geometric parameters $\left(\AA,^{\circ}\right)$ for $\mathbf{4}$.

\begin{tabular}{lrlr}
\hline $\mathrm{Zn} 1-\mathrm{O} 2^{\mathrm{i}}$ & $1.956(3)$ & $\mathrm{Zn} 1-\mathrm{O} 3$ & $2.164(3)$ \\
$\mathrm{Zn} 1-\mathrm{O} 4^{\mathrm{ii}}$ & $1.987(3)$ & $\mathrm{Zn} 1-\mathrm{O} 1$ & $2.240(3)$ \\
$\mathrm{Zn} 1-\mathrm{N} 1$ & $2.014(3)$ & & \\
& & & \\
$\mathrm{O} 2^{\mathrm{i}}-\mathrm{Zn} 1-\mathrm{O} 4^{\mathrm{ii}}$ & $102.10(12)$ & $\mathrm{N} 1-\mathrm{Zn} 1-\mathrm{O} 3$ & $76.38(11)$ \\
$\mathrm{O} 2^{\mathrm{i}}-\mathrm{Zn} 1-\mathrm{N} 1$ & $135.97(12)$ & $\mathrm{O} 2^{\mathrm{i}}-\mathrm{Zn} 1-\mathrm{O} 1$ & $102.52(12)$ \\
$\mathrm{O} 4^{\mathrm{ii}}-\mathrm{Zn} 1-\mathrm{N} 1$ & $121.41(12)$ & $\mathrm{O} 4^{\mathrm{ii}}-\mathrm{Zn} 1-\mathrm{O} 1$ & $102.68(12)$ \\
$\mathrm{O} 2^{\mathrm{i}}-\mathrm{Zn} 1-\mathrm{O} 3$ & $94.78(12)$ & $\mathrm{N} 1-\mathrm{Zn} 1-\mathrm{O} 1$ & $75.85(11)$ \\
$\mathrm{O} 4^{\mathrm{ii}}-\mathrm{Zn} 1-\mathrm{O} 3$ & $94.93(12)$ & $\mathrm{O} 3-\mathrm{Zn} 1-\mathrm{O} 1$ & $151.96(9)$ \\
\hline
\end{tabular}

Symmetry codes: (i) $y,-x+2,-z+1$; (ii) $y,-x+1,-z+1$.

value of $139.20(10)^{\circ}$ (Table 3). A quantitative analysis (Holmes, 1984) places the five-coordination about $\mathrm{Zn}^{\mathrm{II}}$ almost half-way $(48.6 \%)$ along a Berry pseudo-rotation coordinate from trigonal-bipyramidal (idealized point group $D_{3 h}$ ) to square-pyramidal (idealized point group $C_{4 v}$ ). The alternative $\tau$ descriptor for fivefold coordination (Addison et al., 1984) adopts values of 0.20 for $\mathbf{3}$ and 0.27 for $\mathbf{4}$ and thus suggests

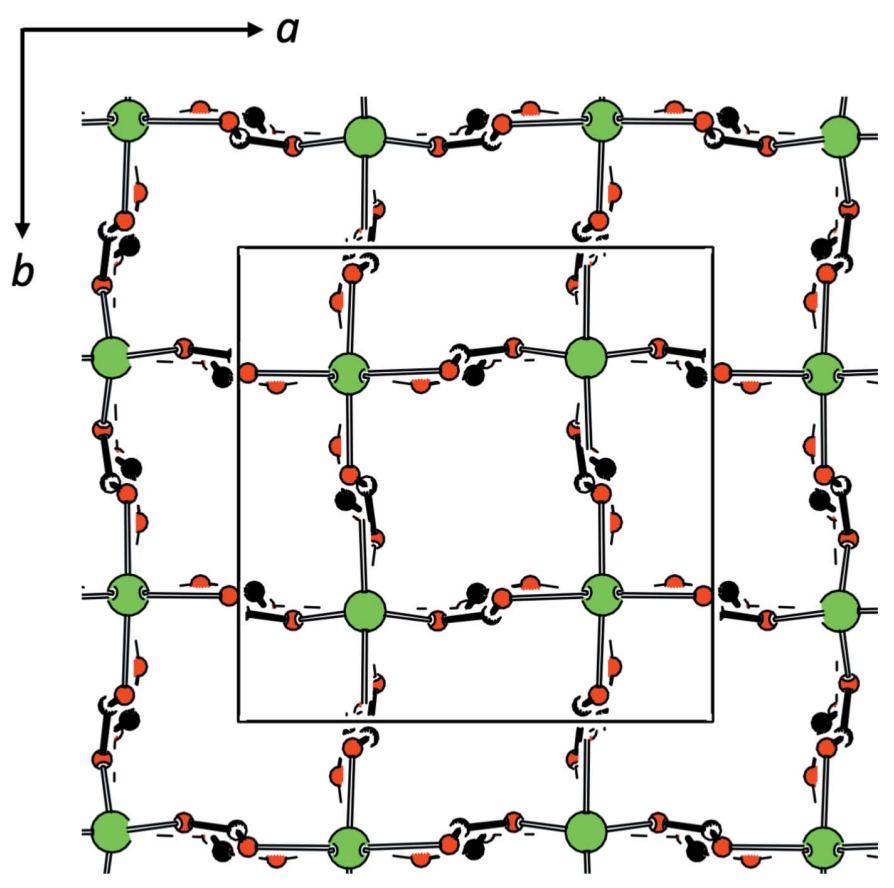

Figure 5

Projection of the unit cell of $\mathbf{3}$ (Spek, 2009); only atoms contributing to the extended connectivity in the (001) plane have been included.
Table 5

Selected geometric parameters $\left(\AA,^{\circ}\right)$ for $\mathbf{5}$.

\begin{tabular}{|c|c|c|c|}
\hline Ni1-N1 & $1.975(5)$ & $\mathrm{Ni1}-\mathrm{O} 3$ & $2.036(4)$ \\
\hline $\mathrm{Ni} 1-\mathrm{O} 4$ & $2.023(5)$ & $\mathrm{Ni1}-\mathrm{O} 1$ & $2.131(3)$ \\
\hline $\mathrm{Ni} 1-\mathrm{O}^{\mathrm{i}}$ & $2.036(4)$ & $\mathrm{Ni} 1-\mathrm{O} 1^{\mathrm{i}}$ & $2.131(3)$ \\
\hline $\mathrm{N} 1-\mathrm{Ni} 1-\mathrm{O} 4$ & 180.0 & $\mathrm{O} 3^{\mathrm{i}}-\mathrm{Ni} 1-\mathrm{O} 1$ & 89.43 (14) \\
\hline $\mathrm{N} 1-\mathrm{Ni} 1-\mathrm{O}^{\mathrm{i}}$ & $94.48(9)$ & $\mathrm{O} 3-\mathrm{Ni} 1-\mathrm{O} 1$ & $92.48(14)$ \\
\hline $\mathrm{O} 4-\mathrm{Ni} 1-\mathrm{O}^{\mathrm{i}}$ & $85.52(9)$ & $\mathrm{N} 1-\mathrm{Ni} 1-\mathrm{O} 1^{\mathrm{i}}$ & $77.70(8)$ \\
\hline $\mathrm{N} 1-\mathrm{Ni} 1-\mathrm{O} 3$ & $94.48(9)$ & $\mathrm{O} 4-\mathrm{Ni} 1-\mathrm{O} 1^{\mathrm{i}}$ & $102.30(8)$ \\
\hline $\mathrm{O} 4-\mathrm{Ni} 1-\mathrm{O} 3$ & $85.52(9)$ & $\mathrm{O} 3^{\mathrm{i}}-\mathrm{Ni} 1-\mathrm{O} 1^{\mathrm{i}}$ & $92.48(14)$ \\
\hline $\mathrm{O}^{\mathrm{i}}-\mathrm{Ni} 1-\mathrm{O} 3$ & $171.03(19)$ & $\mathrm{O} 3-\mathrm{Ni} 1-\mathrm{O} 1^{\mathrm{i}}$ & 89.43 (14) \\
\hline $\mathrm{N} 1-\mathrm{Ni} 1-\mathrm{O} 1$ & $77.70(8)$ & $\mathrm{O} 1-\mathrm{Ni} 1-\mathrm{O} 1^{\mathrm{i}}$ & $155.40(16)$ \\
\hline $\mathrm{O} 4-\mathrm{Ni1}-\mathrm{O} 1$ & $102.30(8)$ & & \\
\hline
\end{tabular}

Symmetry code: (i) $-x+1,-y+\frac{1}{2}, z$.

describing the coordination polyhedra about the divalent cations as distorted square-pyramidal ( $\tau=0$ for ideal squarepyramidal coordination). The $\mathrm{Zn}\left(\mathrm{Lig}^{2}\right)$ units arrange about the $\overline{4}$ axes in the achiral, non-centrosymmetric space group $P \overline{4} 2{ }_{1} c$. Fig. 5 shows a projection of the unit cell in which only those atoms contributing to the extended connectivity of a $\{4,4\}$ net have been included. The shortest secondary interaction in $\mathbf{3}$ is a halogen contact, with $\mathrm{Cl} 1 \cdots \mathrm{O} 1\left(\frac{3}{2}-y, \frac{3}{2}-x\right.$, $\left.\frac{1}{2}+z\right)=3.036(2) \AA$.

Complex $\mathbf{4}$ crystallizes in the same space group as $\mathbf{3}$, with comparable lattice parameters and similar $\mathrm{Zn}^{\mathrm{II}}$ coordination (Fig. 4b, Table 4). In addition to a $\mathrm{Zn}\left(\mathrm{Lig}^{3}\right)$ moiety, its asymmetric unit contains two water molecules on twofold rotation axes; the compound therefore is a monohydrate. The cocrystallized water molecules occupy the twofold axes associated with Wyckoff positions $4 c$ and $4 d$. These water molecules subtend short hydrogen bonds with the hydroxy group of $\mathrm{Lig}^{3}$.

Mononuclear complexes of 4-substituted dicarboxylato pyridine ligands with $\mathrm{Ni}^{\mathrm{II}}$

In contrast to the low-symmetry five-coordinated moieties $\mathrm{Zn}(\mathrm{Lig})\left(\mathrm{Lig}=\mathrm{Lig}^{2}, \mathrm{Lig}^{3}\right)$ which act as building blocks for the extended structures of $\mathbf{3}$ and $\mathbf{4}$, coordination of the same ligands to $\mathrm{Ni}^{\mathrm{II}}$ results in the mononuclear pseudooctahedral complexes 5 and 6. Complex $\mathbf{5}$ crystallizes in the tetragonal space group $I 4_{1} a$, with the complex molecule located on a twofold rotation axis. With the exception of the intra-ligand angle $\mathrm{O} 1-\mathrm{Ni1}-\mathrm{O}^{\mathrm{i}}$ [symmetry code: (i) $-x+1,-y+\frac{1}{2}, z$ ],
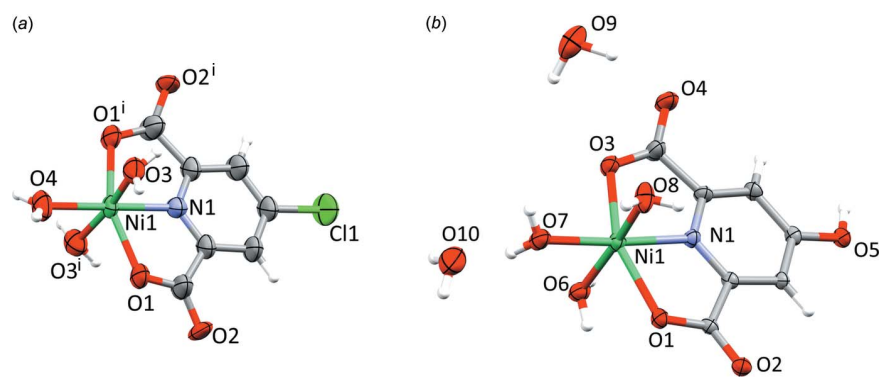

Figure 6

Displacement ellipsoid plots (70\% probability, Macrae et al., 2006) of the asymmetric unit for $(a) \mathbf{5}$ and $(b) \mathbf{6}$; $\mathrm{H}$ atoms are shown as spheres of arbitrary radii. Symmetry code: (i) $1-x, \frac{1}{2}-y, z$. 
Table 6

Selected geometric parameters $\left(\AA,^{\circ}\right)$ for $\mathbf{6}$.

\begin{tabular}{lrlr}
\hline Ni1-N1 & $1.9681(17)$ & $\mathrm{Ni1}-\mathrm{O} 8$ & $2.0848(19)$ \\
$\mathrm{Ni1}-\mathrm{O} 7$ & $2.0082(17)$ & $\mathrm{Ni1}-\mathrm{O} 3$ & $2.1205(16)$ \\
$\mathrm{Ni1}-\mathrm{O} 6$ & $2.0816(18)$ & $\mathrm{Ni1}-\mathrm{O} 1$ & $2.1833(15)$ \\
& & & \\
$\mathrm{N} 1-\mathrm{Ni1}-\mathrm{O} 7$ & $175.97(7)$ & $\mathrm{O} 6-\mathrm{Ni1}-\mathrm{O} 3$ & $93.58(7)$ \\
$\mathrm{N} 1-\mathrm{Ni1}-\mathrm{O} 6$ & $95.02(7)$ & $\mathrm{O} 8-\mathrm{Ni1}-\mathrm{O} 3$ & $91.91(7)$ \\
$\mathrm{O} 7-\mathrm{Ni1}-\mathrm{O} 6$ & $86.66(7)$ & $\mathrm{N} 1-\mathrm{Ni1}-\mathrm{O} 1$ & $76.84(6)$ \\
$\mathrm{N} 1-\mathrm{Ni1}-\mathrm{O} 8$ & $93.23(7)$ & $\mathrm{O} 7-\mathrm{Ni1}-\mathrm{O} 1$ & $106.90(6)$ \\
$\mathrm{O} 7-\mathrm{Ni1}-\mathrm{O} 8$ & $85.38(8)$ & $\mathrm{O} 6-\mathrm{Ni1}-\mathrm{O} 1$ & $88.60(6)$ \\
$\mathrm{O} 6-\mathrm{Ni1}-\mathrm{O} 8$ & $170.86(7)$ & $\mathrm{O} 8-\mathrm{Ni1}-\mathrm{O} 1$ & $89.44(7)$ \\
$\mathrm{N} 1-\mathrm{Ni1}-\mathrm{O} 3$ & $78.58(7)$ & $\mathrm{O} 3-\mathrm{Ni1}-\mathrm{O} 1$ & $155.42(6)$ \\
$\mathrm{O} 7-\mathrm{Ni1}-\mathrm{O} 3$ & $97.67(6)$ & & \\
\hline
\end{tabular}

Table 7

Hydrogen-bond geometry $\left(\AA,^{\circ}\right)$ for $\mathbf{1}$.

\begin{tabular}{|c|c|c|c|c|}
\hline$D-\mathrm{H} \cdots A$ & $D-\mathrm{H}$ & $\mathrm{H} \cdots A$ & $D \cdots A$ & $\overline{D-\mathrm{H} \cdots A}$ \\
\hline $\mathrm{O} 4-\mathrm{H} 4 O \cdots \mathrm{O} 10^{\mathrm{i}}$ & $0.86(2)$ & $1.60(2)$ & $2.451(2)$ & $173(3)$ \\
\hline $\mathrm{O} 8-\mathrm{H} 8 O \cdots \mathrm{O} 9^{\mathrm{ii}}$ & $0.86(2)$ & $1.62(2)$ & $2.478(2)$ & $170(3)$ \\
\hline $\mathrm{O} 9-\mathrm{H} 9 O \cdots \mathrm{O} 2^{\mathrm{iii}}$ & 0.84 & 1.94 & $2.752(2)$ & 164 \\
\hline $\mathrm{O} 9-\mathrm{H} 9 P \cdots \mathrm{O} 2^{\mathrm{i}}$ & 0.84 & 1.88 & $2.709(2)$ & 170 \\
\hline $\mathrm{O} 10-\mathrm{H} 10 O \cdots \mathrm{O} 11 A^{\mathrm{iv}}$ & 0.84 & 1.97 & $2.531(8)$ & 124 \\
\hline $\mathrm{O} 10-\mathrm{H} 10 O \cdots \mathrm{O} 11 B^{\mathrm{iv}}$ & 0.84 & 1.92 & $2.717(6)$ & 158 \\
\hline $\mathrm{O} 10-\mathrm{H} 10 O \cdots \mathrm{O} 11 C^{\mathrm{iv}}$ & 0.84 & 1.96 & $2.607(7)$ & 134 \\
\hline $\mathrm{O} 10-\mathrm{H} 10 P \cdots \mathrm{O} 5$ & 0.84 & 1.86 & $2.676(2)$ & 164 \\
\hline $\mathrm{O} 11 A-\mathrm{H} 11 P \ldots \mathrm{O} 3$ & 0.85 & 2.11 & $2.875(8)$ & 149 \\
\hline $\mathrm{O} 11 C-\mathrm{H} 11 T \cdots \mathrm{O} 3$ & 0.85 & 2.15 & $2.820(8)$ & 136 \\
\hline
\end{tabular}

Symmetry codes: (i) $x,-y+\frac{3}{2}, z-\frac{1}{2}$; (ii) $x, y+1, z$; (iii) $-x, y-\frac{1}{2},-z+\frac{1}{2}$; (iv) $x,-y+\frac{3}{2}, z+\frac{1}{2}$.

the coordination sphere about the transition-metal cation corresponds to a rather regular octahedron (Fig. 6a, Table 5).

Complex 6 is a hydrate; its water content is explained in more detail in the Refinement section. The complex molecule $\left.\left[\mathrm{NiLig}^{2}\left(\mathrm{OH}_{2}\right)_{3}\right)\right]$ (Fig. 6b, Table 6) adopts a very similar geometry to the Cl-substituted compound 5. The analogous mononuclear derivative $\left.\left[\mathrm{NiLig}\left(\mathrm{OH}_{2}\right)_{3}\right)\right]$ has been structurally characterized by Li \& Du (2015).

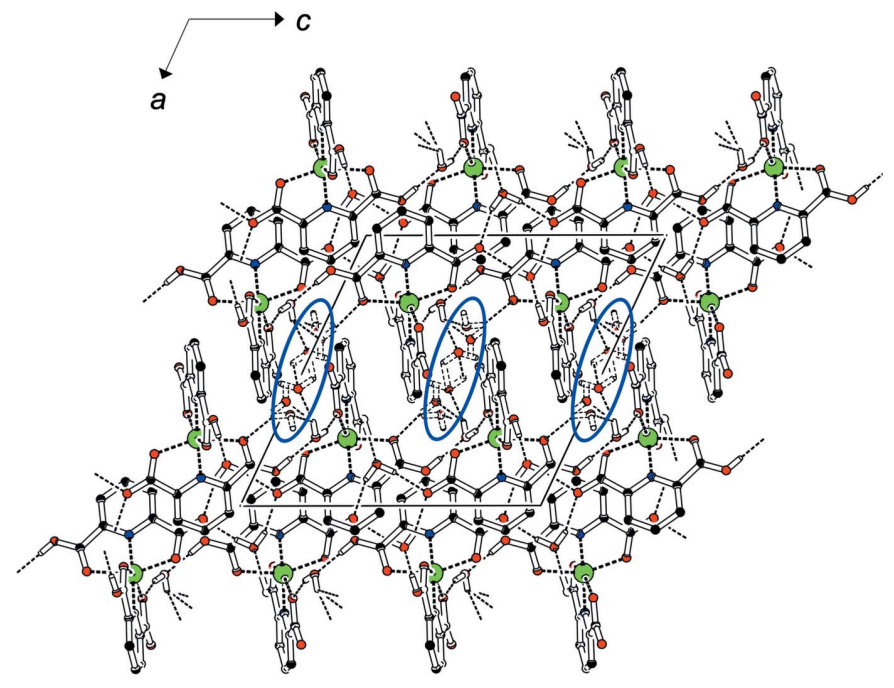

Figure 7

Hydrogen bonds in 2; $\mathrm{H}$ atoms not involved in short contacts have been omitted. The disordered water molecules highlighted in blue connect adjacent layers along [100].
Table 8

Hydrogen-bond geometry $\left(\AA,{ }^{\circ}\right)$ for $\mathbf{2}$.

\begin{tabular}{|c|c|c|c|c|}
\hline$D-\mathrm{H} \cdots A$ & $D-\mathrm{H}$ & $\mathrm{H} \cdots A$ & $D \cdots A$ & $\overline{D-\mathrm{H} \cdots A}$ \\
\hline $\mathrm{O} 4-\mathrm{H} 4 O \cdots \mathrm{O} 10^{\mathrm{i}}$ & $0.84(1)$ & $1.61(1)$ & $2.456(2)$ & $177(3)$ \\
\hline $\mathrm{O} 8-\mathrm{H} 8 \mathrm{O} \cdots \mathrm{O} 9^{\mathrm{ii}}$ & $0.84(1)$ & $1.63(1)$ & $2.462(2)$ & $171(3)$ \\
\hline $\mathrm{O} 9-\mathrm{H} 9 O \cdots \mathrm{O} 2^{\mathrm{iii}}$ & 0.84 & 1.94 & $2.751(2)$ & 162 \\
\hline $\mathrm{O} 9-\mathrm{H} 9 P \cdots \mathrm{O} 2^{\mathrm{i}}$ & 0.84 & 1.84 & $2.678(2)$ & 172 \\
\hline $\mathrm{O} 10-\mathrm{H} 10 O \cdots \mathrm{O} 11 A^{\mathrm{iv}}$ & 0.84 & 1.90 & $2.529(5)$ & 131 \\
\hline $\mathrm{O} 10-\mathrm{H} 10 O \cdots \mathrm{O} 11 B^{\mathrm{iv}}$ & 0.84 & 1.89 & $2.715(8)$ & 166 \\
\hline $\mathrm{O} 10-\mathrm{H} 10 O \cdots \mathrm{O} 11 C^{\mathrm{iv}}$ & 0.84 & 1.86 & $2.581(7)$ & 143 \\
\hline $\mathrm{O} 10-\mathrm{H} 10 P \cdots \mathrm{O} 5$ & 0.84 & 1.78 & $2.608(2)$ & 167 \\
\hline $\mathrm{O} 11 A-\mathrm{H} 11 P \ldots \mathrm{O} 3$ & 0.85 & 2.08 & $2.842(5)$ & 149 \\
\hline $\mathrm{O} 11 C-\mathrm{H} 11 T \cdots \mathrm{O} 3$ & 0.83 & 2.11 & $2.798(8)$ & 140 \\
\hline
\end{tabular}

Symmetry codes: (i) $x,-y+\frac{3}{2}, z-\frac{1}{2}$; (ii) $x, y+1, z$; (iii) $-x, y-\frac{1}{2},-z+\frac{1}{2}$; (iv) $x,-y+\frac{3}{2}, z+\frac{1}{2}$.

Table 9

Hydrogen-bond geometry $\left(\AA{ }^{\circ}\right)$ for 4 .

\begin{tabular}{|c|c|c|c|c|}
\hline$D-\mathrm{H} \cdots A$ & $D-\mathrm{H}$ & $\mathrm{H} \cdots A$ & $D \cdots A$ & $D-\mathrm{H} \cdots A$ \\
\hline $\mathrm{O} 5-\mathrm{H} 5 \mathrm{O} \cdots \mathrm{O} 7$ & $0.82(3)$ & $1.94(3)$ & $2.765(4)$ & $172(6)$ \\
\hline $\mathrm{O} 6-\mathrm{H} 6 P \cdots \mathrm{O} 5^{\mathrm{iii}}$ & 0.84 & 1.95 & $2.782(4)$ & 174 \\
\hline $\mathrm{O} 7-\mathrm{H} 7 A \cdots \mathrm{O} 1^{\mathrm{iv}}$ & 0.84 & 2.38 & $3.220(4)$ & 177 \\
\hline $\mathrm{O} 7-\mathrm{H} 7 A \cdots \mathrm{O} 2^{\mathrm{iv}}$ & 0.84 & 2.50 & $3.098(3)$ & 129 \\
\hline $\mathrm{O} 7-\mathrm{H} 7 B \cdots \mathrm{O} 1^{\mathrm{v}}$ & 0.84 & 2.38 & $3.220(4)$ & 177 \\
\hline $\mathrm{O} 7-\mathrm{H} 7 B \cdots \mathrm{O} 2^{\mathrm{v}}$ & 0.84 & 2.50 & $3.098(3)$ & 129 \\
\hline
\end{tabular}

$\begin{aligned} & \text { Symmetry codes: } \\ & x-1,-y+\frac{3}{2}-z+\frac{3}{2}\end{aligned} \quad-x+2,-y+1, z ; \quad$ (iv) $\quad-x+\frac{3}{2}, y-\frac{1}{2},-z+\frac{3}{2}$; $x-\frac{1}{2},-y+\frac{3}{2},-z+\frac{3}{2}$

Table 10

Hydrogen-bond geometry $\left(\AA{ }^{\circ}\right)$ for $\mathbf{5}$.

\begin{tabular}{lllll}
\hline$D-\mathrm{H} \cdots A$ & $D-\mathrm{H}$ & $\mathrm{H} \cdots A$ & $D \cdots A$ & $D-\mathrm{H} \cdots A$ \\
\hline $\mathrm{O} 3-\mathrm{H} 3 P \cdots \mathrm{O} 2 B^{\mathrm{ii}}$ & $0.81(2)$ & $2.10(3)$ & $2.90(3)$ & $174(5)$ \\
$\mathrm{O} 3-\mathrm{H} 3 P \cdots \mathrm{O} 2 A^{\mathrm{ii}}$ & $0.81(2)$ & $1.85(3)$ & $2.628(18)$ & $162(6)$ \\
$\mathrm{O} 3-\mathrm{H} 3 O \cdots \mathrm{Cl} 1^{\text {iii }}$ & $0.79(2)$ & $2.75(3)$ & $3.464(4)$ & $150(5)$ \\
$\mathrm{O} 4-\mathrm{H} 4 O \cdots \mathrm{O} 2 B^{\text {iv }}$ & $0.79(2)$ & $2.53(6)$ & $2.95(3)$ & $115(5)$ \\
$\mathrm{O} 4-\mathrm{H} 4 O \cdots \mathrm{O} 2 B^{\mathrm{v}}$ & $0.79(2)$ & $2.11(5)$ & $2.83(3)$ & $151(6)$
\end{tabular}

Symmetry codes: (ii) $-y+\frac{5}{4}, x-\frac{3}{4},-z+\frac{5}{4}$; $\quad$ (iii) $-y+\frac{5}{4}, x-\frac{1}{4}, z-\frac{1}{4}$;

\section{Intermolecular interactions}

In all compounds but 3 , classical $\mathrm{O}-\mathrm{H} \cdots \mathrm{O}$ hydrogen bonds occur. In the isostructural solids 1 (Table 7) and 2 (Table 8) the well-ordered water molecules associated with O9 and O10 connect complex molecules via short hydroxyl$\mathrm{OH} \cdots$ water contacts and moderately strong $\mathrm{H}_{2} \mathrm{O} \cdots$ carbonyl contacts into layers in the (100) plane. The disordered water molecule associated with sites $\mathrm{O} 11 A, \mathrm{O} 11 B$ and $\mathrm{O} 11 C$ links adjacent layers along [100] into a three-dimensional hydrogenbonded network; Fig. 7 shows this arrangement for 2 .

Compound $\mathbf{4}$ is a two-dimensional coordination polymer extending parallel to (001); the hydroxyl group is involved both as donor and acceptor in the shortest hydrogen bonds (Table 9) within these layers. The longer hydrogen bonds subtended by the water molecule $\mathrm{O} 7$ link successive layers in the third dimension along [001]. The $\mathrm{Cl}$ substituent in $\mathbf{5}$ accepts a rather long hydrogen bond from an aqua ligand of a neighbouring molecule (Table 10); even without this interaction, $\mathrm{O}-\mathrm{H} \cdots \mathrm{O}$ contacts result in a three-dimensional 
Table 11

Hydrogen-bond geometry $\left(\AA{ }^{\circ}\right)$ for $\mathbf{6}$.

\begin{tabular}{|c|c|c|c|c|}
\hline$D-\mathrm{H} \cdots A$ & $D-\mathrm{H}$ & $\mathrm{H} \cdots A$ & $D \cdots A$ & $D-\mathrm{H} \cdots A$ \\
\hline $\mathrm{O} 5-\mathrm{H} 5 \mathrm{O} \cdots \mathrm{O} 1^{\mathrm{i}}$ & 0.84 & 1.79 & $2.624(2)$ & 169 \\
\hline $\mathrm{O} 6-\mathrm{H} 6 \mathrm{O} \cdots \mathrm{O} 2^{\mathrm{ii}}$ & $0.81(2)$ & $2.07(2)$ & $2.836(2)$ & $158(4)$ \\
\hline $\mathrm{O} 6-\mathrm{H} 6 \mathrm{O} \cdots \mathrm{O} 5^{\mathrm{iii}}$ & $0.81(2)$ & $2.66(4)$ & $3.130(2)$ & $119(3)$ \\
\hline $\mathrm{O} 6-\mathrm{H} 6 P \cdots \mathrm{O} 9^{\mathrm{iv}}$ & $0.84(2)$ & $2.00(2)$ & $2.821(3)$ & $167(4)$ \\
\hline $\mathrm{O} 7-\mathrm{H} 7 P \cdots \mathrm{O}^{\mathrm{v}}$ & $0.81(2)$ & $1.96(2)$ & $2.751(2)$ & $166(4)$ \\
\hline $\mathrm{O} 7-\mathrm{H} 7 \mathrm{O} \cdots \mathrm{O} 10$ & $0.82(2)$ & $2.24(3)$ & $2.989(5)$ & $152(4)$ \\
\hline $\mathrm{O} 7-\mathrm{H} 7 \mathrm{O} \cdots \mathrm{O} 11$ & $0.82(2)$ & $1.77(2)$ & $2.574(5)$ & $170(5)$ \\
\hline $\mathrm{O} 8-\mathrm{H} 8 P \cdots \mathrm{O}^{\mathrm{v}}$ & $0.81(2)$ & $2.00(2)$ & $2.811(3)$ & $173(4)$ \\
\hline $\mathrm{O} 8-\mathrm{H} 8 O \cdots \mathrm{O}^{\mathrm{vi}}$ & $0.82(2)$ & $1.88(2)$ & $2.691(2)$ & $170(3)$ \\
\hline $\mathrm{O} 9-\mathrm{H} 9 O \cdots \mathrm{O} 4 A^{\mathrm{iv}}$ & 0.84 & 2.12 & $2.934(3)$ & 161 \\
\hline $\mathrm{O} 9-\mathrm{H} 9 O \cdots \mathrm{O} 4 B^{\mathrm{iv}}$ & 0.84 & 2.67 & $3.51(2)$ & 175 \\
\hline $\mathrm{O} 9-\mathrm{H} 9 P \cdots \mathrm{O} 4 A$ & 0.84 & 1.93 & $2.729(3)$ & 159 \\
\hline $\mathrm{O} 9-\mathrm{H} 9 P \cdots \mathrm{O} 4 B$ & 0.84 & 1.98 & $2.693(17)$ & 142 \\
\hline
\end{tabular}

Symmetry codes: (i) $\quad x-\frac{1}{2}, y+\frac{1}{2}, z$; $\quad$ (ii) $\quad-x+1,-y+1,-z+1$; $\quad$ (iii) $-x+\frac{1}{2},-y+\frac{3}{2},-z+1$; (iv) $\quad-x+\frac{1}{2}, y-\frac{1}{2},-z+\frac{3}{2} ; \quad$ (v) $\quad-x+1, y,-z+\frac{3}{2}$; $\quad$ (vi) $-x+1,-y+2,-z+1$.

hydrogen-bonded network. Table 11 compiles the hydrogen bonds in 6. All classical hydrogen-bond donors find an acceptor in a suitable geometry, resulting in a three-dimensional network. In contrast to $\mathbf{4}$, the hydroxyl group only acts as a hydrogen-bond donor.

\section{Conclusion and outlook}

In this article we compare coordination compounds of divalent $\mathrm{Ni}^{\mathrm{II}}$ and $\mathrm{Zn}^{\mathrm{II}}$ cations; they share similar ionic radii but differ with respect to their electron configuration. Crystal-field stabilization can be expected for the $d^{8}$ configuration of the former cation whereas no such effects will be observed for the latter with its fully occupied $d$ subshell. A first very direct comparison can be made between compounds $\mathbf{1}$ and $\mathbf{2}$ with octahedral coordination of the metal cations, facilitated by their strict isotypism. In the octahedral environment, the $d$ subshell of $\mathrm{Ni}^{\mathrm{II}}$ splits into a set of three fully occupied $t_{2 g}$ and two half-occupied $e_{g}$ orbitals; the former induce a very regular coordination geometry. In contrast, the fully occupied and hence fully symmetric $d$ subshell of $\mathrm{Zn}^{\mathrm{II}}$ can adapt to any coordination mode. In line with this expectation the $\mathrm{Ni}^{\mathrm{II}}$ complex $\mathbf{2}$ is significantly more regular than its $\mathrm{Zn}^{\mathrm{II}}$ analogue 1. Complexes $\mathbf{3}$ and $\mathbf{4}$ with only one fully deprotonated pyridine-2,6-dicarboxylate ligand adopt a low-symmetry fivefold coordination with the $\mathrm{Zn}^{\mathrm{II}}$ cation - very possible for a fully symmetric $d^{10}$ subshell without any preference for a certain ligand geometry. No such structures exist for the $\mathrm{Ni}^{\mathrm{II}}$ complexes 5 and $\mathbf{6}$ of the same pyridine-2,6-dicarboxylates: additional aqua ligands complete rather regular octahedral coordination environments about the crystal-field-stabilized transition-metal cation with its incomplete $d$ subshell. Our analysis of structures with the same metal:ligand ratio, i.e. $\mathbf{1}$ versus 2 and $\mathbf{3} / \mathbf{4}$ versus $\mathbf{5} / \mathbf{6}$ consistently shows that the central $\mathrm{Ni}^{\mathrm{II}}$ cations with their partially occupied $d$ subshell induce the more regular, crystal-field-stabilized coordination geometry whereas the $d^{10}$-configured $\mathrm{Zn}^{\mathrm{II}}$ cation can adapt to even very unsymmetrical coordination geometries. The structures reported here can be considered a direct experimental proof for the concept of crystal-field stabilization. With respect to our interest in extended structures (Kondraçka \& Englert, 2008; Merkens \& Englert, 2012; Merkens et al., 2012; Kremer \& Englert, 2018), we conclude that substituted pyridine-2,6dicarboxylates may well represent useful linkers between main-group cations in a 1:1 stoichiometry. In this case, the chelating and bridging coordination mode of the dicarboxylato ligand induces a coordination sphere of low symmetry. We expect that the $\mathrm{Ni}^{\mathrm{II}}$ complexes $\mathbf{5}$ and $\mathbf{6}$ are mononuclear because the additional aqua ligands allow the formation of a much more symmetric ligand field. Derivatives of crystal-fieldstabilized transition-metal cations can probably not be isostructural with the coordination polymers 3 and 4 .

\section{Database survey}

Our database surveys aimed at complexes in which a metal is coordinated to the pyridine nitrogen atoms and at least one carboxylate oxygen of pyridine-2,6-dicarboxylic acid or one of its derivatives. They were conducted with Version 5.39 of the CSD (Groom et al., 2016), including the updates of August 2018, and restricted to error-free entries without disorder for which atomic coordinates were available.

\section{Experimental}

\subsection{Synthesis and crystallization}

\section{Compound 1:}

Pyridine-2,6-dicarboxylic acid $\left(\mathrm{H}_{2} \mathrm{Lig}^{1}\right) \quad(247.5 \mathrm{mg}$, $1.48 \mathrm{mmol}$, Sigma-Aldrich) was dissolved in deionized water $(11 \mathrm{ml})$ at $373 \mathrm{~K}$. This solution was added to a solution of $\mathrm{ZnCl}_{2}(101.2 \mathrm{mg}, 0.743 \mathrm{mmol})$ in deionized water $(2 \mathrm{ml})$. Colourless rods were obtained after 15 minutes. Yield: $233.6 \mathrm{mg}(0.517 \mathrm{mmol}, 69.8 \%)$. Analysis calculated for (1): $\mathrm{ZnC}_{14} \mathrm{H}_{8} \mathrm{~N}_{2} \mathrm{O}_{8} \cdot 3 \mathrm{H}_{2} \mathrm{O}$ ): C 37.23, H 3.12, N 6.20; found: C 37.66, $\mathrm{H} 2.87, \mathbf{N} 5.40$. The thermal stability of $\mathbf{1}$ was investigated in detail; the result of the thermogravimetric analysis is represented in the supporting information to this article. It indicates that decomposition occurs in two steps: first, the three cocrystallized water molecules are lost, followed by a second step probably associated with decarboxylation and slow concomitant decomposition.

\section{Compound 2:}

Pyridine-2,6-dicarboxylic acid $\left(\mathrm{H}_{2} \mathrm{Lig}^{1}\right) \quad$ (204.7 $\mathrm{mg}$, $1.23 \mathrm{mmol}$, Sigma-Aldrich) was dissolved in deionized water $(10 \mathrm{ml})$ at $373 \mathrm{~K}$. This solution was added to a solution of $\mathrm{NiCl}_{2} \cdot 6 \mathrm{H}_{2} \mathrm{O}(146.6 \mathrm{mg}, 0.617 \mathrm{mmol})$ in deionized water $(1 \mathrm{ml})$. Green rods were obtained after several days. Yield: $181.2 \mathrm{mg}$ $(0.407 \mathrm{mmol}, 66.5 \%)$. Analysis calculated for 2: $\mathrm{NiC}_{14} \mathrm{H}_{8-}$ $\mathrm{N}_{2} \mathrm{O}_{8} \times 3\left(\mathrm{H}_{2} \mathrm{O}\right)$ : C 37.79, H 3.17, N 6.30; found: C 37.90, H 3.13, N 6.06 .

\section{Compound 3:}

4-Chloropyridine-2,6-dicarboxylic acid $\left(\mathrm{H}_{2} \mathrm{Lig}^{2}\right)$ (60 mg, $0.298 \mathrm{mmol}$, abcr) was dissolved in deionized water $(10 \mathrm{ml})$ and heated to $368 \mathrm{~K}$ without stirring. $\mathrm{ZnCl}_{2}(60.2 \mathrm{mg}$, $0.442 \mathrm{mmol}$, Gruessing) was added to the solution. After $2 \mathrm{~h}$, the heat source was removed, and the solution was left to cool 
to ambient temperature overnight. The crystals were obtained as colourless blocks. Yield: $128.0 \mathrm{mg}(0.483 \mathrm{mmol}, 64.9 \%)$. Analysis calculated for 3: $\mathrm{ZnC}_{7} \mathrm{H}_{2} \mathrm{ClNO}_{4}$ : C 31.73, H 0.76, N 5.29; found: $\mathrm{C} 31.66, \mathrm{H}$ 0.93, N 5.19. Thermal analysis indicated stability of the compound up to a $670 \mathrm{~K}$.

\section{Compound 4:}

4-Hydroxypyridine-2,6-dicarboxylic acid $\left(\mathrm{H}_{2} \mathrm{Lig}^{3}\right)(94.0 \mathrm{mg}$, $0.513 \mathrm{mmol}$, abcr) was dissolved in deionized water $(11 \mathrm{ml})$ and heated to $368 \mathrm{~K}$ without stirring. $\mathrm{ZnCl}_{2}(210 \mathrm{mg}$, $1.54 \mathrm{mmol}$, Gruessing) was added to the solution. After $4 \mathrm{~h}$, the heat source was removed, and the solution was left to cool to ambient temperature overnight. A large excess of metal salt was used to prevent the crystallization of the monohydrate of the ligand. The product was obtained as brown crystalline blocks. Yield: $67.2 \mathrm{mg}(0.273 \mathrm{mmol}, 53.1 \%)$. Although no visible decomposition was observed below $570 \mathrm{~K}$, the analytical data indicate that the co-crystallized water molecule evaporates upon drying of the crystals. Analysis calculated for 4 without $\mathrm{H}_{2} \mathrm{O}, \mathrm{ZnC}_{7} \mathrm{H}_{3} \mathrm{NO}_{5}$ : C 34.11, $\mathrm{H} 1.23, \mathrm{~N}$ 5.68; found: $\mathrm{C}$ 34.10, H 2.23, N 5.69.

\section{Compound 5:}

4-Chloropyridine-2,6-dicarboxylic acid $\left(\mathrm{H}_{2} \mathrm{Lig}^{2}\right)(150 \mathrm{mg}$, $0.744 \mathrm{mmol}$, abcr $)$ was dissolved in ethanol $(10 \mathrm{ml})$. This solution was added to a solution of $\mathrm{NiCl}_{2} \cdot 6 \mathrm{H}_{2} \mathrm{O}(176.9 \mathrm{mg}$, $0.744 \mathrm{mmol}$, Gruessing) in deionized water $(4 \mathrm{ml})$. The crystals were obtained as green rods after several days. Yield: $101.3 \mathrm{mg}$ $(0.324 \mathrm{mmol}, 43.6 \%)$. Despite the good match between the experimental and simulated powder patterns, no fully satisfactory microchemical analysis could be achieved. Analysis calculated for 5: $\mathrm{NiC}_{7} \mathrm{H}_{8} \mathrm{ClNO}_{7}: \mathrm{C} 26.92, \mathrm{H} 2.58, \mathrm{~N}$ 4.46; found: $\mathrm{C} 27.76, \mathrm{H} 2.67, \mathrm{~N}$ 4.35. No visible decomposition was observed below $570 \mathrm{~K}$.

In order to improve the match of the elemental analysis, an alternative synthesis was explored: 4-chloropyridine-2,6-dicarboxylic acid $\left(\mathrm{H}_{2} \mathrm{Lig}^{2}\right)$ (94.6 $\mathrm{mg}, 0.469 \mathrm{mmol}$, abcr) and $\mathrm{NiCO}_{3}(115 \mathrm{mg}, 0.469 \mathrm{mmol})$ were suspended in deionized water $(8 \mathrm{ml}) . \mathrm{CO}_{2}$ was evolved and the solids dissolved. The resulting solution was stored at $423 \mathrm{~K}$ for one $\mathrm{h}$ to evaporate most of the solvent and then kept at room temperature. Further evaporation over a period of one night lead to crystallization. Analysis calculated for $\mathbf{5 :} \mathrm{NiC}_{7} \mathrm{H}_{8} \mathrm{ClNO}_{7}: \mathrm{C} 26.92$, H 2.58, N 4.46; found: C 26.00, H 2.98, N 4.39.

\section{Compound 6:}

4-Hydroxypyridine-2,6-dicarboxylic acid $\left(\mathrm{H}_{2} \mathrm{Lig}^{3}\right)(70.0 \mathrm{mg}$, $0.382 \mathrm{mmol}$, abcr) was dissolved in deionized water $(11 \mathrm{ml})$ at $373 \mathrm{~K}$. This solution was added to a solution of $\mathrm{NiCl}_{2} \cdot 6 \mathrm{H}_{2} \mathrm{O}$ $(181.7 \mathrm{mg}, 0.764 \mathrm{mmol})$ in deionized water $(1 \mathrm{ml})$. The product was obtained as brown crystalline blocks after several days. An excess of metal salt was used to prevent the crystallization of the monohydrate of the ligand. Yield: $75.8 \mathrm{mg}(0.247 \mathrm{mmol}$, $64.6 \%$ ). Analysis calculated for 6: $\mathrm{C}_{7} \mathrm{H}_{9} \mathrm{NNiO}_{8} \cdot 1.7\left(\mathrm{H}_{2} \mathrm{O}\right)$ : $\mathrm{C}$ 25.91, H 3.85, N 4.32; found: C 26.11, H 3.69, N 4.44. No visible decomposition was observed below $570 \mathrm{~K}$.

For all solids 1-6 matching powder patterns (see supporting information) confirmed that the bulk samples essentially correspond to the structures derived from single crystal diffraction experiments.

\subsection{Powder diffraction}

$\mathrm{X}$-ray powder diffraction experiments were performed at ambient temperature on flat samples with a Stoe STADI P diffractometer equipped with an image plate detector with constant $\omega$ angle of $55^{\circ}$ using germanium-monochromated $\mathrm{Cu}$ $K_{\alpha 1}$ radiation $(\lambda=1.54059 \AA)$. Powder patterns for 1-6 are given in the supporting information.

\subsection{Refinement}

Crystal data, data collection parameters and convergence results for the single crystal X-ray diffraction experiments are summarized in Table 12. Non-hydrogen atoms were assigned anisotropic displacement parameters. $\mathrm{H}$ atoms attached to carbon were introduced into calculated positions and treated as riding with $U_{\text {iso }}(\mathrm{H})=1.2 U_{\text {eq }}(\mathrm{C}) . \mathrm{H}$ atoms attached to oxygen were located from difference-Fourier maps. In $\mathbf{1}$ and $\mathbf{2}$, the coordinates of the hydrogen atoms in the carboxylic acid groups were refined and their $U_{\text {iso }}$ values constrained to $1.5 U_{\text {eq }}(\mathrm{O}) ; \mathrm{H}$ atoms in water molecules were refined as riding on $\mathrm{O}$, in the geometry detected by the difference-Fourier syntheses with an idealized $\mathrm{O}-\mathrm{H}$ distance of $0.84 \AA$ A. In $\mathbf{4}$, the coordinates of the hydroxy $\mathrm{H}$ atom were refined with an $\mathrm{O}-\mathrm{H}$ distance restraint; $\mathrm{H}$ atoms in the water molecules were refined as riding on $\mathrm{O}$, in the geometry detected by the difference-Fourier syntheses with an idealized $\mathrm{O}-\mathrm{H}$ distance of $0.84 \AA$. In $\mathbf{5}$, the coordinates of the $\mathrm{H}$ atoms associated with the aqua ligands were refined with $\mathrm{O}-\mathrm{H}$ distance restraints. In 6, the coordinates of the $\mathrm{H}$ atoms associated with the aqua ligands and with hydroxy group were refined with $\mathrm{O}-\mathrm{H}$ distance restraints; $\mathrm{H}$ atoms attached to the co-crystallized water molecules were refined as riding on oxygen, in the geometry detected by the difference-Fourier synthesis with an idealized $\mathrm{O}-\mathrm{-H}$ distance of $0.84 \AA$. One of the solvent water molecules in $\mathbf{1}$ and $\mathbf{2}$ is disordered over three mutually exclusive positions; the sum of its site occupancies was restrained to unity. In $\mathbf{5}$, the non-coordinating carboxylato $\mathrm{O}$ atom in the asymmetric unit was treated as disordered; the sum of its site occupancies was constrained to unity. In 6, a water molecule is in part located on a twofold axis, in part on a general position close to this axis. Tentative treatment of the electron density in this void with BYPASS/SQUEEZE (van der Sluis \& Spek, 1990; Spek, 2009) suggests an overall content of 50 electrons, corresponding to five water molecules per cell or 0.63 water molecules per asymmetric unit, in good agreement with our refined water content of 0.7 molecules per asymmetric unit. One of the two non-coordinating carboxylato $\mathrm{O}$ atoms was treated as disordered over two positions; the sum of the site occupancies was constrained to unity. As the occupancies of the mutually exclusive sites converged to very different values, the minority site was only assigned an isotropic displacement parameter. Our structure model, with a disordered water molecule in part located on a twofold axis and in part on a general position close to this axis, is similar to that of Fronczek (2015). In contrast, Cui et al. (2006) and Aghabozorg et al. (2007) have described the same water site 
Table 12

Experimental details.

Crystal data

Chemical formula

$M_{\mathrm{r}}$

Crystal system, space group

Temperature $(\mathrm{K})$

$a, b, c(\AA)$

$\alpha, \beta, \gamma\left({ }^{\circ}\right)$

$V\left(\AA^{3}\right)$

Z

Radiation type

$\mu\left(\mathrm{mm}^{-1}\right)$

Crystal size (mm)

Data collection

Diffractometer

Absorption correction

$T_{\min }, T_{\max }$

No. of measured, independent and observed $[I>2 \sigma(I)]$ reflections

$R_{\text {int }}$

$(\sin \theta / \lambda)_{\max }\left(\AA^{-1}\right)$

Refinement

$R\left[F^{2}>2 \sigma\left(F^{2}\right)\right], w R\left(F^{2}\right), S$

No. of reflections

No. of parameters

No. of restraints

$\mathrm{H}$-atom treatment

$\Delta \rho_{\max }, \Delta \rho_{\min }\left(\mathrm{e} \AA^{-3}\right)$

Absolute structure

Absolute structure parameter
1

2

$\left[\mathrm{Zn}\left(\mathrm{C}_{7} \mathrm{H}_{4} \mathrm{NO}_{4}\right)_{2}\right] \cdot 3 \mathrm{H}_{2} \mathrm{O}$

451.64

Monoclinic, $P 2_{1} / c$

220

13.9953 (8), 10.0081 (6),

$13.7330(8)$

90, 116.4303 (14), 90

1722.48 (18)

4

Mo $K \alpha$

1.49

$0.28 \times 0.18 \times 0.18$

Bruker APEX CCD

Multi-scan $S A D A B S$ (Bruker,

2008)

$0.877,1.000$

$56614,5777,4180$

0.054

0.737

$0.037,0.105,1.04$

5777

263

2

$\mathrm{H}$ atoms treated by a mixture of independent and constrained refinement

$0.56,-0.35$

2
3

$\left[\mathrm{Ni}\left(\mathrm{C}_{7} \mathrm{H}_{4} \mathrm{NO}_{4}\right)_{2}\right] \cdot 3 \mathrm{H}_{2} \mathrm{O}$

444.98

Monoclinic, $P 2_{1} / c$

250

13.6651 (15), 10.0207 (11),

$13.7696(15)$

90, $115.109(2), 90$

1707.3 (3)

Mo $K \alpha$

1.20

$0.40 \times 0.12 \times 0.12$

$\left[\mathrm{Zn}\left(\mathrm{C}_{7} \mathrm{H}_{2} \mathrm{ClNO}_{4}\right)\right]$

264.94

Tetragonal, $P \overline{4} 2_{1} c$

100

10.0293 (5), 10.0293 (5),

$16.8924(9)$

90, 90, 90

1699.15 (19)

Mo $K \alpha$

3.19

$0.25 \times 0.10 \times 0.10$

Bruker APEX CCD

Multi-scan $S A D A B S$ (Bruker, 2008)

$0.821,1.000$

25725, 5107, 3629

0.043

0.718

Bruker APEX CCD

Multi-scan $S A D A B S$ (Bruker, 2008)

$0.590,0.746$

25321, 2592, 2266

0.059

0.717

$0.039,0.128,1.03$

5107

$0.026,0.064,1.07$

2592

128

$\mathrm{H}$ atoms treated by a mixture of independent and constrained refinement

$0.56,-0.35$

$-$
0

$\mathrm{H}$-atom parameters constrained

$0.42,-0.31$

Refined as an inversion twin 0.41 (2)

5

\section{Crystal data}

Chemical formula

$M_{\mathrm{r}}$

Crystal system, space group

Temperature (K)

$a, b, c(\AA)$

$\alpha, \beta, \gamma\left({ }^{\circ}\right)$
$V\left(\AA^{3}\right)$

Radiation type

$\mu\left(\mathrm{mm}^{-1}\right)$

Crystal size (mm)

Data collection

Diffractometer

Absorption correction

$T_{\min }, T_{\max }$

No. of measured, independent and observed $[I>2 \sigma(I)]$ reflections

$R_{\text {int }}$

$(\sin \theta / \lambda)_{\max }\left(\AA^{-1}\right)$

$\left[\mathrm{Zn}\left(\mathrm{C}_{7} \mathrm{H}_{3} \mathrm{NO}_{5}\right)\right] \cdot \mathrm{H}_{2} \mathrm{O}$

529.02

Tetragonal, $P \overline{4} 2_{1} c$

100

10.050 (1), 10.050 (1), 16.5060 (16)

$90,90,90$

$1667.1(4)$

4

Mo $K \alpha$

2.96

$0.16 \times 0.10 \times 0.09$

Bruker APEX CCD

Multi-scan $S A D A B S$ (Bruker, 2008)

$0.497,0.746$

$24393,2567,2371$

0.047

0.723

$0.033,0.079,1.07$

2567

141

1

$\mathrm{H}$ atoms treated by a mixture of independent and constrained refinement
$\left[\mathrm{Ni}\left(\mathrm{C}_{7} \mathrm{H}_{2} \mathrm{ClNO}_{4}\right)\left(\mathrm{H}_{2} \mathrm{O}\right)_{3}\right]$

312.30

Tetragonal, $I 4_{1} / a$

250

9.544 (2), 9.544 (2), 23.361 (5)

90, 90, 90

2127.9 (11)

Mo $K \alpha$

2.10

$0.40 \times 0.25 \times 0.18$

Bruker APEX CCD

Multi-scan $S A D A B S$ (Bruker, 2008)

$0.468,0.745$

$12540,1127,935$

0.092

0.634

$0.050,0.127,1.14$

1127

99

8

$\mathrm{H}$ atoms treated by a mixture of independent and constrained refinement
6

$\left[\mathrm{Ni}\left(\mathrm{C}_{7} \mathrm{H}_{3} \mathrm{NO}_{5}\right)\left(\mathrm{H}_{2} \mathrm{O}\right)_{3}\right] \cdot 1.7 \mathrm{H}_{2} \mathrm{O}$

324.49

Monoclinic, $C 2 / c$

100

14.7249 (11), 6.8538 (5),

$22.3510(16)$

90, 90.355 (1), 90

2255.7 (3)

Mo $K \alpha$

1.77

$0.33 \times 0.32 \times 0.12$

Bruker APEX CCD

Multi-scan $S A D A B S$ (Bruker, 2008)

$0.569,0.746$

$16693,3368,2963$

0.027

0.725

$0.039,0.106,1.17$

3368

214

12

$\mathrm{H}$ atoms treated by a mixture of independent and constrained refinement 
Table 12 (continued)

\begin{tabular}{|c|c|c|c|}
\hline & 4 & 5 & 6 \\
\hline$\Delta \rho_{\max }, \Delta \rho_{\min }\left(\mathrm{e} \AA^{-3}\right)$ & $0.70,-0.46$ & $0.50,-0.51$ & $0.79,-0.52$ \\
\hline Absolute structure & Refined as an inversion twin & $?$ & - \\
\hline Absolute structure parameter & $0.47(2)$ & $?$ & - \\
\hline
\end{tabular}

Computer programs: SMART (Bruker, 2001), SAINT-Plus (Bruker, 2009), SHELXT (Sheldrick, 2015a), SHELXL2013 (Sheldrick, 2015b) and Mercury (Macrae et al. (2006).

by a single electron density maximum associated with a very large displacement parameter.

\subsection{Thermal analyses}

Thermogravimetric analyses (see supporting information) were performed under $\mathrm{N}_{2}$ with a heating rate of $5 \mathrm{~K} \mathrm{~min}^{-1}$ for (1) and $10 \mathrm{~K} \mathrm{~min}^{-1}$ for $\mathbf{3}$ with a Mettler Toledo TGA/SDTA 851e instrument.

\section{Acknowledgements}

We thank Ina Stickeler for preliminary work with 1, Niklas Polter for the synthesis and analytical characterization, and Stefanie Noelke for the new synthesis route to $\mathbf{5}$.

\section{References}

Addison, A. W., Rao, T. N., Reedijk, J., van Rijn, J. \& Verschoor, G. C. (1984). J. Chem. Soc. Dalton Trans. pp. 1349-1356.

Aghabozorg, H., Ghadermazi, M., Soleimannejad, J. \& Sheshmani, S. (2007). Acta Cryst. E63, m1917-m1918.

Baruah, J. B. (2016). Private communication (refcode PYDCNI08). CCDC, Cambridge, England.

Bruker (2001). SMART. Bruker AXS Inc., Madison, Wisconsin, USA.

Bruker (2008). SADABS. Bruker AXS Inc., Madison, Wisconsin, USA.

Bruker (2009). SAINT+. Bruker AXS Inc., Madison, Wisconsin, USA.

Cui, J.-Z., Zhang, H., Shi, Y.-Q., Chen, B. \& Gao, H.-L. (2006). Acta Cryst. E62, m2057-m2058.

Fronczek, F. R. (2015). Private communication (refcode MENWEI02). CCDC, Cambridge, England.

Gao, H.-L., Yi, L., Zhao, B., Zhao, X.-Q., Cheng, P., Liao, D.-Z. \& Yan, S.-P. (2006). Inorg. Chem. 45, 5980-5988.

Gaw, H., Robinson, W. R. \& Walton, R. A. (1971). Inorg. Nucl. Chem. Lett. 7, 695-699.

Groom, C. R., Bruno, I. J., Lightfoot, M. P. \& Ward, S. C. (2016). Acta Cryst. B72, 171-179.
Håkansson, K., Lindahl, M., Svensson, G. \& Albertsson, J. (1993). Acta Chem. Scand. 47, 449-455.

Holmes, R. R. (1984). Prog. Inorg. Chem. 32, 119-235.

Kondraçka, M. \& Englert, U. (2008). Inorg. Chem. 47, 10246-10257.

Kremer, M. \& Englert, U. (2018). Z. Kristallogr. 233, 437-452.

Li, J.-X. \& Du, Z.-X. (2015). Z. Naturforsch. Teil B, 70, 505-511.

Macrae, C. F., Edgington, P. R., McCabe, P., Pidcock, E., Shields, G. P., Taylor, R., Towler, M. \& van de Streek, J. (2006). J. Appl. Cryst. 39, 453-457.

Merkens, C., Becker, N., Lamberts, K. \& Englert, U. (2012). Dalton Trans. 41, 8594-8599.

Merkens, C. \& Englert, U. (2012). Dalton Trans. 41, 4664-4673.

Mirzaei, M. (2016). Private communication (refcode PYDCNI07). CCDC, Cambridge, England.

Mirzaei, M., Eshtiagh-Hosseini, H., Karrabi, Z., Molčanov, K., Eydizadeh, E., Mague, J. T., Bauzá, A. \& Frontera, A. (2014). CrystEngComm, 16, 5352-5363.

Moghimi, A., Ranjbar, M., Aghabozorg, H., Jalali, F., Shamsipur, M. \& Chadah, R. K. (2002). J. Chem. Res. pp. 477-479.

Müller, U. (2013). Symmetry Relationships between Crystal Structures. Oxford University Press.

Nathan, L. C. \& Mai, T. D. (2000). J. Chem. Crystallogr. 30, 509-518.

Okabe, N. \& Oya, N. (2000). Acta Cryst. C56, 305-307.

Quaglieri, P., Loiseleur, H. \& Thomas, G. (1972). Acta Cryst. B28, 2583-2590.

Sanotra, S., Gupta, R., Sheikh, H. N., Kalsotra, B. L., Gupta, V. K. \& Rajnikant (2012). Acta Cryst. B68, 619-624.

Shannon, R. D. (1976). Acta Cryst. A32, 751-767.

Sheldrick, G. M. (2015a). Acta Cryst. A71, 3-8.

Sheldrick, G. M. (2015b). Acta Cryst. C71, 3-8.

Sluis, P. van der \& Spek, A. L. (1990). Acta Cryst. A46, 194-201.

Spek, A. L. (2009). Acta Cryst. D65, 148-155.

Villa, A. C., Guastini, C., Musatti, A. \& Nardelli, M. (1972). Gazz. Chim. Ital. 102, 226-233.

Wang, L., Li, J. \& Wang, E. (2004). Chem. Res. Chin. Univ. 20, 127130.

Zhong, X., Wang, X., Jiang, Y. \& Lu, D. (2004). Guangxi Shifan Daxue Xuebao Ziran Kexueban (J. Guangxi Normal Univ.), 22, 4952.

Zhou, G.-W., Lan, Y.-Z., Zheng, F.-K., Zhang, X., Lin, M.-H., Guo, G.-C. \& Huang, J.-S. (2006). Chem. Phys. Lett. 426, 341-344. 


\section{supporting information}

Acta Cryst. (2019). E75, 903-911［https://doi.org/10.1107/S2056989019007461]

\section{Zn and Ni complexes of pyridine-2,6-dicarboxylates: crystal field stabilization matters!}

\section{Marius Kremer and Ulli Englert}

Computing details

For all structures, data collection: SMART (Bruker, 2001); cell refinement: SAINT-Plus (Bruker, 2009); data reduction: SAINT-Plus (Bruker, 2009); program(s) used to solve structure: SHELXT (Sheldrick, 2015a); program(s) used to refine structure: SHELXL2013 (Sheldrick, 2015b); molecular graphics: Mercury (Macrae et al. (2006); software used to prepare material for publication: SHELXL2013 (Sheldrick, 2015b).

Bis(6-carboxypicolinato)zinc(II) trihydrate (1)

Crystal data

$\left[\mathrm{Zn}\left(\mathrm{C}_{7} \mathrm{H}_{4} \mathrm{NO}_{4}\right)_{2}\right] \cdot 3 \mathrm{H}_{2} \mathrm{O}$

$M_{r}=451.64$

Monoclinic, $P 2{ }_{1} / c$

$a=13.9953(8) \AA$

$b=10.0081(6) \AA$

$c=13.7330(8) \AA$

$\beta=116.4303(14)^{\circ}$

$V=1722.48(18) \AA^{3}$

$Z=4$

\section{Data collection}

Bruker APEX CCD diffractometer

Radiation source: microsource $\omega$ scans

Absorption correction: multi-scan

SADABS (Bruker, 2008)

$T_{\min }=0.877, T_{\max }=1.000$

56614 measured reflections

\section{Refinement}

Refinement on $F^{2}$

Least-squares matrix: full

$R\left[F^{2}>2 \sigma\left(F^{2}\right)\right]=0.037$

$w R\left(F^{2}\right)=0.105$

$S=1.04$

5777 reflections

263 parameters

2 restraints
$F(000)=920$

$D_{\mathrm{x}}=1.742 \mathrm{Mg} \mathrm{m}^{-3}$

Mo $K \alpha$ radiation, $\lambda=0.71073 \AA$

Cell parameters from 7944 reflections

$\theta=2.6-23.8^{\circ}$

$\mu=1.49 \mathrm{~mm}^{-1}$

$T=220 \mathrm{~K}$

Rod, colourless

$0.28 \times 0.18 \times 0.18 \mathrm{~mm}$

5777 independent reflections

4180 reflections with $I>2 \sigma(I)$

$R_{\text {int }}=0.054$

$\theta_{\max }=31.6^{\circ}, \theta_{\min }=1.6^{\circ}$

$h=-20 \rightarrow 20$

$k=-14 \rightarrow 14$

$l=-20 \rightarrow 20$

Hydrogen site location: mixed

$\mathrm{H}$ atoms treated by a mixture of independent and constrained refinement

$w=1 /\left[\sigma^{2}\left(F_{\mathrm{o}}^{2}\right)+(0.0416 P)^{2}+1.0164 P\right]$ where $P=\left(F_{\mathrm{o}}{ }^{2}+2 F_{\mathrm{c}}{ }^{2}\right) / 3$

$(\Delta / \sigma)_{\max }=0.001$

$\Delta \rho_{\max }=0.56 \mathrm{e} \AA^{-3}$

$\Delta \rho_{\min }=-0.35$ e $\AA^{-3}$ 


\section{Special details}

Geometry. All esds (except the esd in the dihedral angle between two 1.s. planes) are estimated using the full covariance matrix. The cell esds are taken into account individually in the estimation of esds in distances, angles and torsion angles; correlations between esds in cell parameters are only used when they are defined by crystal symmetry. An approximate (isotropic) treatment of cell esds is used for estimating esds involving l.s. planes.

Fractional atomic coordinates and isotropic or equivalent isotropic displacement parameters $\left(\AA^{2}\right)$

\begin{tabular}{|c|c|c|c|c|c|}
\hline & $x$ & $y$ & $z$ & $U_{\text {iso }} * / U_{\text {eq }}$ & Occ. $(<1)$ \\
\hline Zn1 & $0.25020(2)$ & $0.99549(2)$ & $0.26138(2)$ & $0.03318(8)$ & \\
\hline $\mathrm{O} 1$ & $0.18718(11)$ & $1.00856(15)$ & $0.37285(11)$ & $0.0362(3)$ & \\
\hline $\mathrm{O} 2$ & $0.03924(12)$ & $0.96743(16)$ & $0.39055(12)$ & $0.0394(3)$ & \\
\hline $\mathrm{O} 3$ & $0.23801(11)$ & $0.94497(16)$ & $0.09052(11)$ & $0.0376(3)$ & \\
\hline $\mathrm{O} 4$ & $0.12629(14)$ & $0.84401(16)$ & $-0.06458(12)$ & $0.0423(3)$ & \\
\hline $\mathrm{H} 4 \mathrm{O}$ & $0.174(2)$ & $0.854(3)$ & $-0.088(2)$ & $0.063^{*}$ & \\
\hline O5 & $0.34985(13)$ & $0.82750(15)$ & $0.33256(13)$ & $0.0429(3)$ & \\
\hline O6 & $0.52279(16)$ & $0.7743(2)$ & $0.42790(16)$ & $0.0655(5)$ & \\
\hline O7 & $0.22321(11)$ & $1.21877(14)$ & $0.21460(12)$ & $0.0368(3)$ & \\
\hline $\mathrm{O} 8$ & $0.31855(13)$ & $1.40197(16)$ & $0.22226(14)$ & $0.0445(4)$ & \\
\hline $\mathrm{H} 8 \mathrm{O}$ & $0.2576(17)$ & $1.437(3)$ & $0.180(2)$ & $0.067^{*}$ & \\
\hline N1 & $0.10463(12)$ & $0.91469(15)$ & $0.17479(12)$ & 0.0273 & \\
\hline $\mathrm{N} 2$ & $0.39644(11)$ & $1.07655(17)$ & $0.31645(12)$ & $0.0296(3)$ & \\
\hline $\mathrm{C} 1$ & $0.04345(14)$ & $0.90384(18)$ & $0.22605(14)$ & $0.0286(3)$ & \\
\hline $\mathrm{C} 2$ & $-0.05478(15)$ & $0.8403(2)$ & $0.17755(16)$ & $0.0351(4)$ & \\
\hline $\mathrm{H} 2$ & -0.097679 & 0.832445 & 0.213942 & $0.042 *$ & \\
\hline $\mathrm{C} 3$ & $-0.08801(16)$ & $0.7885(2)$ & $0.07356(17)$ & 0.0379 (4) & \\
\hline H3 & -0.154381 & 0.745240 & 0.038598 & $0.045^{*}$ & \\
\hline $\mathrm{C} 4$ & $-0.02338(16)$ & 0.80052 (19) & $0.02125(16)$ & $0.0341(4)$ & \\
\hline $\mathrm{H} 4$ & -0.044877 & 0.765742 & -0.048981 & $0.041^{*}$ & \\
\hline $\mathrm{C} 5$ & $0.07331(14)$ & $0.86496(18)$ & $0.07525(14)$ & $0.0285(3)$ & \\
\hline C6 & $0.09289(15)$ & 0.96503 (19) & $0.33896(15)$ & $0.0307(4)$ & \\
\hline $\mathrm{C} 7$ & $0.15363(16)$ & 0.88719 (19) & $0.03184(15)$ & $0.0316(4)$ & \\
\hline $\mathrm{C} 8$ & $0.47935(15)$ & $0.9954(2)$ & $0.36847(15)$ & $0.0342(4)$ & \\
\hline C9 & $0.58359(16)$ & $1.0440(3)$ & $0.40976(17)$ & $0.0457(5)$ & \\
\hline H9 & 0.642028 & 0.987024 & 0.447096 & $0.055^{*}$ & \\
\hline $\mathrm{C} 10$ & $0.59927(17)$ & $1.1759(3)$ & $0.39499(19)$ & $0.0489(6)$ & \\
\hline H10 & 0.668946 & 1.210052 & 0.421825 & $0.059^{*}$ & \\
\hline C11 & $0.51240(16)$ & $1.2593(3)$ & $0.34041(17)$ & $0.0424(5)$ & \\
\hline H11 & 0.521956 & 1.350086 & 0.329531 & $0.051 *$ & \\
\hline $\mathrm{C} 12$ & $0.41133(14)$ & $1.2049(2)$ & $0.30250(15)$ & $0.0323(4)$ & \\
\hline $\mathrm{C} 13$ & $0.45005(18)$ & $0.8530(2)$ & $0.37782(17)$ & $0.0418(5)$ & \\
\hline C14 & $0.30825(15)$ & $1.2785(2)$ & $0.24167(15)$ & $0.0323(4)$ & \\
\hline O9 & $0.15287(13)$ & $0.52698(17)$ & $0.10985(13)$ & $0.0443(4)$ & \\
\hline $\mathrm{H} 9 \mathrm{O}$ & 0.100266 & 0.513987 & 0.122694 & $0.053^{*}$ & \\
\hline H9P & 0.124646 & 0.529706 & 0.041594 & $0.053^{*}$ & \\
\hline $\mathrm{O} 10$ & $0.25352(15)$ & $0.61084(17)$ & $0.36169(14)$ & $0.0536(4)$ & \\
\hline $\mathrm{H} 10 \mathrm{O}$ & 0.309944 & 0.565544 & 0.386735 & $0.064 *$ & \\
\hline $\mathrm{H} 10 \mathrm{P}$ & 0.275684 & 0.677054 & 0.340055 & $0.064 *$ & \\
\hline
\end{tabular}




\begin{tabular}{llllll} 
O11A & $0.3323(7)$ & $1.0949(9)$ & $-0.0231(7)$ & $0.0653(12)^{*}$ & $0.283(5)$ \\
H11O & 0.283003 & 1.152053 & -0.052998 & $0.078^{*}$ & $0.283(5)$ \\
H11P & 0.327964 & 1.056784 & 0.029852 & $0.078^{*}$ & $0.283(5)$ \\
O11B & $0.4329(5)$ & $1.0244(6)$ & $-0.0055(5)$ & $0.0653(12)^{*}$ & $0.371(5)$ \\
H11Q & 0.452158 & 0.999978 & 0.059700 & $0.078^{*}$ & $0.371(5)$ \\
H11R & 0.470448 & 1.022909 & -0.039770 & $0.078^{*}$ & $0.371(5)$ \\
O11C & $0.3815(7)$ & $1.0466(8)$ & $0.0158(6)$ & $0.0653(12)^{*}$ & $0.321(6)$ \\
H11S & 0.443940 & 1.014077 & 0.041684 & $0.078^{*}$ & $0.321(6)$ \\
H11T & 0.341329 & 1.061387 & 0.046024 & $0.078^{*}$ & $0.321(6)$ \\
\hline
\end{tabular}

Atomic displacement parameters $\left(\AA^{2}\right)$

\begin{tabular}{lllllll}
\hline & $U^{11}$ & $U^{22}$ & $U^{33}$ & $U^{12}$ & $U^{13}$ & $U^{23}$ \\
\hline Zn1 & $0.02530(11)$ & $0.03862(14)$ & $0.03201(12)$ & $-0.00359(8)$ & $0.00950(9)$ & $-0.00199(9)$ \\
O1 & $0.0296(6)$ & $0.0479(8)$ & $0.0298(7)$ & $-0.0058(6)$ & $0.0121(5)$ & $-0.0074(6)$ \\
O2 & $0.0382(7)$ & $0.0507(9)$ & $0.0347(7)$ & $-0.0027(6)$ & $0.0211(6)$ & $-0.0046(6)$ \\
O3 & $0.0357(7)$ & $0.0452(8)$ & $0.0334(7)$ & $-0.0045(6)$ & $0.0168(6)$ & $-0.0053(6)$ \\
O4 & $0.0551(9)$ & $0.0451(8)$ & $0.0305(7)$ & $-0.0081(7)$ & $0.0225(7)$ & $-0.0081(6)$ \\
O5 & $0.0475(9)$ & $0.0386(8)$ & $0.0426(8)$ & $0.0067(6)$ & $0.0201(7)$ & $0.0061(6)$ \\
O6 & $0.0645(12)$ & $0.0670(12)$ & $0.0634(12)$ & $0.0364(10)$ & $0.0270(10)$ & $0.0235(10)$ \\
O7 & $0.0258(6)$ & $0.0377(8)$ & $0.0393(7)$ & $-0.0005(5)$ & $0.0077(5)$ & $0.0012(6)$ \\
O8 & $0.0408(8)$ & $0.0393(8)$ & $0.0520(9)$ & $-0.0021(7)$ & $0.0193(7)$ & $0.0085(7)$ \\
N1 & $0.0272(7)$ & $0.0273(7)$ & $0.0254(7)$ & $0.0001(6)$ & $0.0099(6)$ & $-0.0002(5)$ \\
N2 & $0.0224(6)$ & $0.0407(9)$ & $0.0241(7)$ & $0.0030(6)$ & $0.0088(5)$ & $0.0005(6)$ \\
C1 & $0.0287(8)$ & $0.0280(8)$ & $0.0281(8)$ & $0.0013(7)$ & $0.0118(7)$ & $0.0021(6)$ \\
C2 & $0.0326(9)$ & $0.0347(10)$ & $0.0376(10)$ & $-0.0048(7)$ & $0.0153(8)$ & $-0.0001(8)$ \\
C3 & $0.0317(9)$ & $0.0360(10)$ & $0.0384(10)$ & $-0.0087(8)$ & $0.0088(8)$ & $-0.0029(8)$ \\
C4 & $0.0370(10)$ & $0.0293(9)$ & $0.0285(9)$ & $-0.0026(7)$ & $0.0078(7)$ & $-0.0027(7)$ \\
C5 & $0.0320(9)$ & $0.0250(8)$ & $0.0249(8)$ & $0.0013(7)$ & $0.0094(7)$ & $0.0013(6)$ \\
C6 & $0.0315(9)$ & $0.0309(9)$ & $0.0287(8)$ & $0.0017(7)$ & $0.0124(7)$ & $0.0012(7)$ \\
C7 & $0.0387(10)$ & $0.0276(9)$ & $0.0286(8)$ & $0.0029(7)$ & $0.0150(7)$ & $0.0011(7)$ \\
C8 & $0.0276(8)$ & $0.0514(12)$ & $0.0232(8)$ & $0.0090(8)$ & $0.0109(7)$ & $0.0018(8)$ \\
C9 & $0.0254(9)$ & $0.0793(17)$ & $0.0296(9)$ & $0.0107(10)$ & $0.0097(7)$ & $-0.0009(10)$ \\
C10 & $0.0255(9)$ & $0.0786(18)$ & $0.0403(11)$ & $-0.0070(10)$ & $0.0125(8)$ & $-0.0045(11)$ \\
C11 & $0.0325(10)$ & $0.0581(14)$ & $0.0362(10)$ & $-0.0121(9)$ & $0.0149(8)$ & $-0.0045(9)$ \\
C12 & $0.0281(8)$ & $0.0428(10)$ & $0.0250(8)$ & $-0.0030(7)$ & $0.0110(7)$ & $-0.0020(7)$ \\
C13 & $0.0437(11)$ & $0.0502(12)$ & $0.0328(10)$ & $0.0182(9)$ & $0.0184(9)$ & $0.0072(9)$ \\
C14 & $0.0316(9)$ & $0.0384(10)$ & $0.0261(8)$ & $-0.0018(7)$ & $0.0122(7)$ & $-0.0009(7)$ \\
O9 & $0.0416(8)$ & $0.0559(10)$ & $0.0343(7)$ & $0.0058(7)$ & $0.0159(7)$ & $0.0084(7)$ \\
O10 & $0.0737(12)$ & $0.0474(10)$ & $0.0563(10)$ & $0.0038(8)$ & $0.0438(9)$ & $0.0023(8)$ \\
& & & & & & \\
& & & & & &
\end{tabular}

Geometric parameters $\left(\AA,{ }^{\circ}\right)$

\begin{tabular}{llll}
\hline $\mathrm{Zn} 1-\mathrm{N} 2$ & $2.0102(15)$ & $\mathrm{C} 3-\mathrm{C} 4$ & $1.388(3)$ \\
$\mathrm{Zn} 1-\mathrm{N} 1$ & $2.0155(15)$ & $\mathrm{C} 3-\mathrm{H} 3$ & 0.9400 \\
$\mathrm{Zn} 1-\mathrm{O} 1$ & $2.0833(14)$ & $\mathrm{C} 4-\mathrm{C} 5$ & $1.380(3)$ \\
$\mathrm{Zn} 1-\mathrm{O} 5$ & $2.1245(15)$ & $\mathrm{C} 4-\mathrm{H} 4$ & 0.9400 \\
$\mathrm{Zn} 1-\mathrm{O} 7$ & $2.3093(15)$ & $\mathrm{C} 5-\mathrm{C} 7$ & $1.505(3)$
\end{tabular}




\begin{tabular}{|c|c|c|c|}
\hline $\mathrm{Zn} 1-\mathrm{O} 3$ & $2.3312(14)$ & $\mathrm{C} 8-\mathrm{C} 9$ & $1.397(3)$ \\
\hline $\mathrm{O} 1-\mathrm{C} 6$ & $1.265(2)$ & $\mathrm{C} 8-\mathrm{C} 13$ & $1.504(3)$ \\
\hline $\mathrm{O} 2-\mathrm{C} 6$ & $1.241(2)$ & $\mathrm{C} 9-\mathrm{C} 10$ & $1.368(4)$ \\
\hline $\mathrm{O} 3-\mathrm{C} 7$ & $1.237(2)$ & $\mathrm{C} 9-\mathrm{H} 9$ & 0.9400 \\
\hline $\mathrm{O} 4-\mathrm{C} 7$ & $1.279(2)$ & $\mathrm{C} 10-\mathrm{C} 11$ & $1.388(3)$ \\
\hline $\mathrm{O} 4-\mathrm{H} 4 \mathrm{O}$ & $0.856(17)$ & $\mathrm{C} 10-\mathrm{H} 10$ & 0.9400 \\
\hline $\mathrm{O} 5-\mathrm{C} 13$ & $1.281(3)$ & $\mathrm{C} 11-\mathrm{C} 12$ & $1.383(3)$ \\
\hline $\mathrm{O} 6-\mathrm{C} 13$ & $1.228(3)$ & $\mathrm{C} 11-\mathrm{H} 11$ & 0.9400 \\
\hline $\mathrm{O} 7-\mathrm{C} 14$ & $1.232(2)$ & $\mathrm{C} 12-\mathrm{C} 14$ & $1.500(3)$ \\
\hline $\mathrm{O} 8-\mathrm{C} 14$ & $1.286(2)$ & $\mathrm{O} 9-\mathrm{H} 9 \mathrm{O}$ & 0.8400 \\
\hline $\mathrm{O} 8-\mathrm{H} 8 \mathrm{O}$ & $0.862(17)$ & O9- $\mathrm{H} 9 \mathrm{P}$ & 0.8401 \\
\hline $\mathrm{N} 1-\mathrm{C} 5$ & $1.332(2)$ & $\mathrm{O} 10-\mathrm{H} 10 \mathrm{O}$ & 0.8400 \\
\hline $\mathrm{N} 1-\mathrm{C} 1$ & $1.333(2)$ & $\mathrm{O} 10-\mathrm{H} 10 \mathrm{P}$ & 0.8400 \\
\hline $\mathrm{N} 2-\mathrm{C} 12$ & $1.328(3)$ & $\mathrm{O} 11 \mathrm{~A}-\mathrm{H} 11 \mathrm{O}$ & 0.8482 \\
\hline $\mathrm{N} 2-\mathrm{C} 8$ & $1.334(2)$ & $\mathrm{O} 11 \mathrm{~A}-\mathrm{H} 11 \mathrm{P}$ & 0.8477 \\
\hline $\mathrm{C} 1-\mathrm{C} 2$ & $1.387(3)$ & O11B-H11Q & 0.8485 \\
\hline $\mathrm{C} 1-\mathrm{C} 6$ & $1.518(3)$ & O11B-H11R & 0.8473 \\
\hline $\mathrm{C} 2-\mathrm{C} 3$ & $1.390(3)$ & $\mathrm{O} 11 \mathrm{C}-\mathrm{H} 11 \mathrm{~S}$ & 0.8482 \\
\hline $\mathrm{C} 2-\mathrm{H} 2$ & 0.9400 & $\mathrm{O} 11 \mathrm{C}-\mathrm{H} 11 \mathrm{~T}$ & 0.8472 \\
\hline $\mathrm{N} 2-\mathrm{Zn} 1-\mathrm{N} 1$ & $167.53(6)$ & $\mathrm{C} 5-\mathrm{C} 4-\mathrm{H} 4$ & 120.9 \\
\hline $\mathrm{N} 2-\mathrm{Zn} 1-\mathrm{O} 1$ & $113.04(6)$ & $\mathrm{C} 3-\mathrm{C} 4-\mathrm{H} 4$ & 120.9 \\
\hline $\mathrm{N} 1-\mathrm{Zn} 1-\mathrm{O} 1$ & $79.13(6)$ & $\mathrm{N} 1-\mathrm{C} 5-\mathrm{C} 4$ & $121.48(17)$ \\
\hline $\mathrm{N} 2-\mathrm{Zn} 1-\mathrm{O} 5$ & $78.25(6)$ & $\mathrm{N} 1-\mathrm{C} 5-\mathrm{C} 7$ & $112.87(16)$ \\
\hline $\mathrm{N} 1-\mathrm{Zn} 1-\mathrm{O} 5$ & $103.77(6)$ & $\mathrm{C} 4-\mathrm{C} 5-\mathrm{C} 7$ & $125.65(17)$ \\
\hline $\mathrm{O} 1-\mathrm{Zn} 1-\mathrm{O} 5$ & $96.75(6)$ & $\mathrm{O} 2-\mathrm{C} 6-\mathrm{O} 1$ & $125.48(18)$ \\
\hline $\mathrm{N} 2-\mathrm{Zn} 1-\mathrm{O} 7$ & $74.17(6)$ & $\mathrm{O} 2-\mathrm{C} 6-\mathrm{C} 1$ & $118.34(17)$ \\
\hline $\mathrm{N} 1-\mathrm{Zn} 1-\mathrm{O} 7$ & $103.12(5)$ & $\mathrm{O} 1-\mathrm{C} 6-\mathrm{C} 1$ & $116.18(16)$ \\
\hline $\mathrm{O} 1-\mathrm{Zn} 1-\mathrm{O} 7$ & $94.21(6)$ & $\mathrm{O} 3-\mathrm{C} 7-\mathrm{O} 4$ & $126.24(19)$ \\
\hline $\mathrm{O} 5-\mathrm{Zn} 1-\mathrm{O} 7$ & $152.42(6)$ & $\mathrm{O} 3-\mathrm{C} 7-\mathrm{C} 5$ & $118.40(16)$ \\
\hline $\mathrm{N} 2-\mathrm{Zn} 1-\mathrm{O} 3$ & $94.15(6)$ & $\mathrm{O} 4-\mathrm{C} 7-\mathrm{C} 5$ & $115.35(17)$ \\
\hline $\mathrm{N} 1-\mathrm{Zn} 1-\mathrm{O} 3$ & $73.57(5)$ & $\mathrm{N} 2-\mathrm{C} 8-\mathrm{C} 9$ & $120.5(2)$ \\
\hline $\mathrm{O} 1-\mathrm{Zn} 1-\mathrm{O} 3$ & $152.62(5)$ & $\mathrm{N} 2-\mathrm{C} 8-\mathrm{C} 13$ & $114.68(17)$ \\
\hline $\mathrm{O} 5-\mathrm{Zn} 1-\mathrm{O} 3$ & $91.74(6)$ & $\mathrm{C} 9-\mathrm{C} 8-\mathrm{C} 13$ & $124.81(19)$ \\
\hline $\mathrm{O} 7-\mathrm{Zn} 1-\mathrm{O} 3$ & $90.01(5)$ & $\mathrm{C} 10-\mathrm{C} 9-\mathrm{C} 8$ & $118.9(2)$ \\
\hline $\mathrm{C} 6-\mathrm{O} 1-\mathrm{Zn} 1$ & $114.93(12)$ & $\mathrm{C} 10-\mathrm{C} 9-\mathrm{H} 9$ & 120.5 \\
\hline $\mathrm{C} 7-\mathrm{O} 3-\mathrm{Zn} 1$ & $112.20(12)$ & $\mathrm{C} 8-\mathrm{C} 9-\mathrm{H} 9$ & 120.5 \\
\hline $\mathrm{C} 7-\mathrm{O} 4-\mathrm{H} 4 \mathrm{O}$ & $115(2)$ & $\mathrm{C} 9-\mathrm{C} 10-\mathrm{C} 11$ & $120.0(2)$ \\
\hline $\mathrm{C} 13-\mathrm{O} 5-\mathrm{Zn} 1$ & $114.70(14)$ & $\mathrm{C} 9-\mathrm{C} 10-\mathrm{H} 10$ & 120.0 \\
\hline $\mathrm{C} 14-\mathrm{O} 7-\mathrm{Zn} 1$ & $111.66(13)$ & $\mathrm{C} 11-\mathrm{C} 10-\mathrm{H} 10$ & 120.0 \\
\hline $\mathrm{C} 14-\mathrm{O} 8-\mathrm{H} 8 \mathrm{O}$ & $111(2)$ & $\mathrm{C} 12-\mathrm{C} 11-\mathrm{C} 10$ & $118.0(2)$ \\
\hline $\mathrm{C} 5-\mathrm{N} 1-\mathrm{C} 1$ & $121.07(16)$ & $\mathrm{C} 12-\mathrm{C} 11-\mathrm{H} 11$ & 121.0 \\
\hline $\mathrm{C} 5-\mathrm{N} 1-\mathrm{Zn} 1$ & $122.67(12)$ & $\mathrm{C} 10-\mathrm{C} 11-\mathrm{H} 11$ & 121.0 \\
\hline $\mathrm{C} 1-\mathrm{N} 1-\mathrm{Zn} 1$ & $116.06(12)$ & $\mathrm{N} 2-\mathrm{C} 12-\mathrm{C} 11$ & $121.75(19)$ \\
\hline $\mathrm{C} 12-\mathrm{N} 2-\mathrm{C} 8$ & $120.74(17)$ & $\mathrm{N} 2-\mathrm{C} 12-\mathrm{C} 14$ & $112.43(16)$ \\
\hline $\mathrm{C} 12-\mathrm{N} 2-\mathrm{Zn} 1$ & $122.32(12)$ & $\mathrm{C} 11-\mathrm{C} 12-\mathrm{C} 14$ & $125.8(2)$ \\
\hline $\mathrm{C} 8-\mathrm{N} 2-\mathrm{Zn} 1$ & $116.94(14)$ & $\mathrm{O} 6-\mathrm{C} 13-\mathrm{O} 5$ & $126.8(2)$ \\
\hline $\mathrm{N} 1-\mathrm{C} 1-\mathrm{C} 2$ & $121.08(17)$ & $\mathrm{O} 6-\mathrm{C} 13-\mathrm{C} 8$ & $117.8(2)$ \\
\hline
\end{tabular}




$\begin{array}{llll}\mathrm{N} 1-\mathrm{C} 1-\mathrm{C} 6 & 113.51(15) & \mathrm{O} 5-\mathrm{C} 13-\mathrm{C} 8 & 115.38(17) \\ \mathrm{C} 2-\mathrm{C} 1-\mathrm{C} 6 & 125.41(17) & \mathrm{O} 7-\mathrm{C} 14-\mathrm{O} 8 & 125.88(18) \\ \mathrm{C} 1-\mathrm{C} 2-\mathrm{C} 3 & 118.11(18) & \mathrm{O} 7-\mathrm{C} 14-\mathrm{C} 12 & 119.36(18) \\ \mathrm{C} 1-\mathrm{C} 2-\mathrm{H} 2 & 120.9 & \mathrm{O} 8-\mathrm{C} 14-\mathrm{C} 12 & 114.76(17) \\ \mathrm{C} 3-\mathrm{C} 2-\mathrm{H} 2 & 120.9 & \mathrm{H} 9 \mathrm{O}-\mathrm{O}-\mathrm{H} 9 \mathrm{P} & 102.6 \\ \mathrm{C} 4-\mathrm{C} 3-\mathrm{C} 2 & 120.13(18) & \mathrm{H} 10 \mathrm{O}-\mathrm{O} 10-\mathrm{H} 10 \mathrm{P} & 98.2 \\ \mathrm{C} 4-\mathrm{C} 3-\mathrm{H} 3 & 119.9 & \mathrm{H} 11 \mathrm{O}-\mathrm{O} 11 \mathrm{~A}-\mathrm{H} 11 \mathrm{P} & 111.4 \\ \mathrm{C} 2-\mathrm{C} 3-\mathrm{H} 3 & 119.9 & \mathrm{H} 11 \mathrm{Q}-\mathrm{O} 11 \mathrm{~B}-\mathrm{H} 11 \mathrm{R} & 126.6 \\ \mathrm{C} 5-\mathrm{C} 4-\mathrm{C} 3 & 118.13(18) & \mathrm{H} 11 \mathrm{~S}-\mathrm{O} 11 \mathrm{C}-\mathrm{H} 11 \mathrm{~T} & 130.3\end{array}$

Hydrogen-bond geometry $\left(A,{ }^{\circ}\right)$

\begin{tabular}{lllll}
\hline$D-\mathrm{H} \cdots A$ & $D-\mathrm{H}$ & $\mathrm{H} \cdots A$ & $D \cdots A$ & $D-\mathrm{H} \cdots A$ \\
\hline $\mathrm{O} 4-\mathrm{H} 4 O \cdots \mathrm{O} 10^{\mathrm{i}}$ & $0.86(2)$ & $1.60(2)$ & $2.451(2)$ & $173(3)$ \\
$\mathrm{O} 8-\mathrm{H} 8 O \cdots \mathrm{O} 9^{\mathrm{ii}}$ & $0.86(2)$ & $1.62(2)$ & $2.478(2)$ & $170(3)$ \\
$\mathrm{C} 2-\mathrm{H} 2 \cdots \mathrm{O} 7^{\mathrm{iii}}$ & 0.94 & 2.62 & $3.512(2)$ & 158 \\
$\mathrm{C} 4-\mathrm{H} 4 \cdots 7^{\mathrm{iv}}$ & 0.94 & 2.52 & $3.207(2)$ & 130 \\
$\mathrm{C} 9-\mathrm{H} 9 \cdots{ }^{\mathrm{v}}$ & 0.94 & 2.56 & $3.310(3)$ & 137 \\
$\mathrm{O} 9-\mathrm{H} 9 O \cdots \mathrm{O} 2^{\mathrm{iii}}$ & 0.84 & 1.94 & $2.752(2)$ & 164 \\
$\mathrm{O} 9-\mathrm{H} 9 P \cdots \mathrm{O} 2^{\mathrm{i}}$ & 0.84 & 1.88 & $2.709(2)$ & 170 \\
$\mathrm{O} 10-\mathrm{H} 10 O \cdots \mathrm{O} 11 A^{\mathrm{vi}}$ & 0.84 & 1.97 & $2.531(8)$ & 124 \\
$\mathrm{O} 10-\mathrm{H} 10 O \cdots \mathrm{O} 11 B^{\mathrm{vi}}$ & 0.84 & 1.92 & $2.717(6)$ & 158 \\
$\mathrm{O} 10-\mathrm{H} 10 O \cdots \mathrm{O} 11 C^{\mathrm{vi}}$ & 0.84 & 1.96 & $2.607(7)$ & 134 \\
$\mathrm{O} 10-\mathrm{H} 10 P \cdots \mathrm{O} 5$ & 0.84 & 1.86 & $2.676(2)$ & 164 \\
$\mathrm{O} 11 A-\mathrm{H} 11 P \cdots \mathrm{O} 3$ & 0.85 & 2.11 & $2.875(8)$ & 149 \\
$\mathrm{O} 11 C-\mathrm{H} 11 T \cdots \mathrm{O} 3$ & 0.85 & 2.15 & $2.820(8)$ & 136
\end{tabular}

Symmetry codes: (i) $x,-y+3 / 2, z-1 / 2$; (ii) $x, y+1, z$; (iii) $-x, y-1 / 2,-z+1 / 2$; (iv) $-x,-y+2,-z$; (v) $-x+1,-y+2,-z+1$; (vi) $x,-y+3 / 2, z+1 / 2$.

Bis(6-carboxypicolinato)nickel(II) trihydrate (2)

Crystal data

$\left[\mathrm{Ni}\left(\mathrm{C}_{7} \mathrm{H}_{4} \mathrm{NO}_{4}\right)_{2}\right] \cdot 3 \mathrm{H}_{2} \mathrm{O}$

$M_{r}=444.98$

Monoclinic, $P 2{ }_{1} / c$

$a=13.6651(15) \AA$

$b=10.0207(11) \AA$

$c=13.7696(15) \AA$

$\beta=115.109(2)^{\circ}$

$V=1707.3(3) \AA^{3}$

$Z=4$

\section{Data collection}

\section{Bruker APEX CCD}

diffractometer

Radiation source: microsource

Multilayer optics monochromator

$\omega$ scans

Absorption correction: multi-scan

SADABS (Bruker, 2008)

$T_{\min }=0.821, T_{\max }=1.000$
$F(000)=912$

$D_{\mathrm{x}}=1.731 \mathrm{Mg} \mathrm{m}^{-3}$

Mo $K \alpha$ radiation, $\lambda=0.71073 \AA$

Cell parameters from 3808 reflections

$\theta=2.6-24.0^{\circ}$

$\mu=1.20 \mathrm{~mm}^{-1}$

$T=250 \mathrm{~K}$

Rod, green

$0.40 \times 0.12 \times 0.12 \mathrm{~mm}$

25725 measured reflections

5107 independent reflections

3629 reflections with $I>2 \sigma(I)$

$R_{\text {int }}=0.043$

$\theta_{\text {max }}=30.7^{\circ}, \theta_{\min }=1.7^{\circ}$

$h=-19 \rightarrow 19$

$k=-14 \rightarrow 14$

$l=-18 \rightarrow 18$ 


\section{Refinement}

Refinement on $F^{2}$

Least-squares matrix: full

$R\left[F^{2}>2 \sigma\left(F^{2}\right)\right]=0.039$

$w R\left(F^{2}\right)=0.128$

$S=1.03$

5107 reflections

263 parameters

2 restraints
Hydrogen site location: mixed

$\mathrm{H}$ atoms treated by a mixture of independent and constrained refinement

$w=1 /\left[\sigma^{2}\left(F_{0}^{2}\right)+(0.0751 P)^{2}\right]$

where $P=\left(F_{\mathrm{o}}^{2}+2 F_{\mathrm{c}}{ }^{2}\right) / 3$

$(\Delta / \sigma)_{\max }=0.001$

$\Delta \rho_{\max }=0.56 \mathrm{e} \AA^{-3}$

$\Delta \rho_{\min }=-0.35$ e $\AA^{-3}$

Special details

Geometry. All esds (except the esd in the dihedral angle between two 1.s. planes) are estimated using the full covariance matrix. The cell esds are taken into account individually in the estimation of esds in distances, angles and torsion angles; correlations between esds in cell parameters are only used when they are defined by crystal symmetry. An approximate (isotropic) treatment of cell esds is used for estimating esds involving l.s. planes.

Fractional atomic coordinates and isotropic or equivalent isotropic displacement parameters $\left(\AA^{2}\right)$

\begin{tabular}{|c|c|c|c|c|c|}
\hline & $x$ & $y$ & $z$ & $U_{\text {iso }} * / U_{\text {eq }}$ & Occ. $(<1)$ \\
\hline Ni1 & $0.24979(2)$ & $0.99449(2)$ & $0.24731(2)$ & $0.02691(10)$ & \\
\hline $\mathrm{O} 1$ & $0.19331(12)$ & $1.01090(13)$ & $0.36653(12)$ & $0.0338(3)$ & \\
\hline $\mathrm{O} 2$ & $0.04726(12)$ & $0.97036(16)$ & $0.39563(12)$ & $0.0383(3)$ & \\
\hline $\mathrm{O} 3$ & $0.24067(11)$ & $0.94554(15)$ & $0.09043(11)$ & $0.0348(3)$ & \\
\hline $\mathrm{O} 4$ & $0.12899(14)$ & $0.84593(16)$ & $-0.06334(12)$ & $0.0428(4)$ & \\
\hline $\mathrm{H} 4 \mathrm{O}$ & $0.1726(19)$ & $0.858(3)$ & $-0.091(2)$ & $0.064^{*}$ & \\
\hline O5 & $0.34228(12)$ & $0.82400(14)$ & $0.31849(12)$ & 0.0390 & \\
\hline O6 & $0.51339(15)$ & $0.7616(2)$ & $0.41861(16)$ & $0.0651(5)$ & \\
\hline $\mathrm{O} 7$ & $0.22425(11)$ & $1.20706(14)$ & $0.20609(12)$ & $0.0345(3)$ & \\
\hline O8 & $0.31904(12)$ & $1.39512(15)$ & $0.22348(13)$ & $0.0426(4)$ & \\
\hline $\mathrm{H} 8 \mathrm{O}$ & $0.2599(12)$ & $1.429(3)$ & $0.1812(18)$ & $0.064 *$ & \\
\hline O9 & $0.15328(14)$ & $0.51674(16)$ & $0.10952(13)$ & $0.0431(4)$ & \\
\hline $\mathrm{H} 9 \mathrm{O}$ & 0.099413 & 0.503432 & 0.122688 & $0.052 *$ & \\
\hline H9P & 0.125443 & 0.519432 & 0.042198 & $0.052 *$ & \\
\hline $\mathrm{O} 10$ & $0.25374(15)$ & $0.61017(16)$ & $0.35421(13)$ & $0.0513(4)$ & \\
\hline $\mathrm{H} 10 \mathrm{O}$ & 0.310150 & 0.564961 & 0.386267 & $0.062 *$ & \\
\hline $\mathrm{H} 10 \mathrm{P}$ & 0.276030 & 0.676781 & 0.332447 & $0.062 *$ & \\
\hline O11A & $0.3367(4)$ & $1.0882(5)$ & -0.0253 & $0.0577(11)^{*}$ & $0.400(5)$ \\
\hline $\mathrm{H} 11 \mathrm{O}$ & 0.287358 & 1.145334 & -0.055164 & $0.069^{*}$ & $0.400(5)$ \\
\hline H11P & 0.332319 & 1.050065 & 0.027686 & $0.069^{*}$ & $0.400(5)$ \\
\hline O11B & $0.4335(7)$ & $1.0224(7)$ & $-0.0113(7)$ & $0.0577(11)^{*}$ & $0.251(5)$ \\
\hline H11Q & 0.452844 & 0.998035 & 0.053904 & $0.069^{*}$ & $0.251(5)$ \\
\hline H11R & 0.471134 & 1.020965 & -0.045566 & $0.069 *$ & $0.251(5)$ \\
\hline $\mathrm{O} 11 \mathrm{C}$ & $0.3853(7)$ & $1.0352(7)$ & $0.0095(6)$ & $0.0577(11)^{*}$ & $0.316(5)$ \\
\hline H11S & 0.447772 & 1.002625 & 0.035351 & $0.069^{*}$ & $0.316(5)$ \\
\hline $\mathrm{H} 11 \mathrm{~T}$ & 0.345162 & 1.049934 & 0.039691 & $0.069^{*}$ & $0.316(5)$ \\
\hline N1 & $0.10530(12)$ & $0.91467(15)$ & $0.17465(12)$ & 0.0259 & \\
\hline $\mathrm{N} 2$ & $0.39703(12)$ & 1.06957 (17) & $0.31357(12)$ & $0.0282(3)$ & \\
\hline $\mathrm{C} 1$ & $0.04515(15)$ & $0.90427(18)$ & $0.22897(15)$ & $0.0273(4)$ & \\
\hline $\mathrm{C} 2$ & $-0.05419(16)$ & $0.8408(2)$ & $0.18435(17)$ & $0.0349(4)$ & \\
\hline
\end{tabular}




$\begin{array}{lllll}\text { H2 } & -0.096504 & 0.832386 & 0.222898 & 0.042^{*} \\ \text { C3 } & -0.08993(17) & 0.7894(2) & 0.08062(17) & 0.0363(5) \\ \text { H3 } & -0.157642 & 0.747267 & 0.048053 & 0.044^{*} \\ \text { C4 } & -0.02563(16) & 0.80065(19) & 0.02566(16) & 0.0330(4) \\ \text { H4 } & -0.048272 & 0.765639 & -0.043847 & 0.040^{*} \\ \text { C5 } & 0.07249(15) & 0.86464(18) & 0.07594(15) & 0.0274(4) \\ \text { C6 } & 0.09866(16) & 0.96665(19) & 0.33975(15) & 0.0284(4) \\ \text { C7 } & 0.15467(16) & 0.88739(18) & 0.03159(15) & 0.0300(4) \\ \text { C8 } & 0.47876(17) & 0.9870(2) & 0.36699(16) & 0.0327(5) \\ \text { C9 } & 0.58453(17) & 1.0347(3) & 0.41499(17) & 0.0422(5) \\ \text { H9 } & 0.642284 & 0.976971 & 0.453447 & 0.051^{*} \\ \text { C10 } & 0.60270(18) & 1.1673(3) & 0.40509(19) & 0.0464(6) \\ \text { H10 } & 0.673571 & 1.201014 & 0.436732 & 0.056^{*} \\ \text { C11 } & 0.51676(17) & 1.2525(2) & 0.34838(17) & 0.0404(5) \\ \text { H11 } & 0.528277 & 1.343723 & 0.340975 & 0.049^{*} \\ \text { C12 } & 0.41416(15) & 1.1987(2) & 0.30345(15) & 0.0300(4) \\ \text { C13 } & 0.44463(18) & 0.8449(2) & 0.36941(18) & 0.0396(5) \\ \text { C14 } & 0.31013(16) & 1.2704(2) & 0.23926(15) & 0.0308(4) \\ & & & & \end{array}$

Atomic displacement parameters $\left(\AA^{2}\right)$

\begin{tabular}{lllllll}
\hline & $U^{11}$ & $U^{22}$ & $U^{33}$ & $U^{12}$ & $U^{13}$ & $U^{23}$ \\
\hline Ni1 & $0.02258(16)$ & $0.03142(16)$ & $0.02550(17)$ & $-0.00112(9)$ & $0.00903(12)$ & $-0.00065(9)$ \\
O1 & $0.0284(8)$ & $0.0450(9)$ & $0.0271(8)$ & $-0.0037(6)$ & $0.0110(6)$ & $-0.0068(6)$ \\
O2 & $0.0352(8)$ & $0.0542(9)$ & $0.0306(8)$ & $-0.0047(7)$ & $0.0188(7)$ & $-0.0057(7)$ \\
O3 & $0.0339(8)$ & $0.0414(8)$ & $0.0331(8)$ & $-0.0030(6)$ & $0.0181(6)$ & $-0.0025(6)$ \\
O4 & $0.0553(10)$ & $0.0485(9)$ & $0.0315(8)$ & $-0.0078(8)$ & $0.0251(7)$ & $-0.0083(7)$ \\
O5 & $0.0433(9)$ & $0.0357(8)$ & $0.0400(9)$ & $0.0053(6)$ & $0.0197(7)$ & $0.0072(6)$ \\
O6 & $0.0620(12)$ & $0.0644(12)$ & $0.0712(13)$ & $0.0334(10)$ & $0.0304(10)$ & $0.0295(10)$ \\
O7 & $0.0250(7)$ & $0.0367(7)$ & $0.0355(8)$ & $0.0000(6)$ & $0.0068(6)$ & $0.0008(6)$ \\
O8 & $0.0405(9)$ & $0.0359(8)$ & $0.0488(10)$ & $-0.0020(7)$ & $0.0162(8)$ & $0.0055(7)$ \\
O9 & $0.0393(9)$ & $0.0565(10)$ & $0.0320(8)$ & $0.0068(7)$ & $0.0137(7)$ & $0.0100(7)$ \\
O10 & $0.0692(12)$ & $0.0425(9)$ & $0.0553(11)$ & $0.0030(8)$ & $0.0391(9)$ & $0.0025(8)$ \\
N1 & $0.0258(8)$ & $0.0270(7)$ & $0.0243(8)$ & $-0.0006(6)$ & $0.0101(6)$ & $-0.0004(6)$ \\
N2 & $0.0217(8)$ & $0.0404(9)$ & $0.0219(8)$ & $0.0020(7)$ & $0.0085(6)$ & $0.0006(7)$ \\
C1 & $0.0280(9)$ & $0.0277(9)$ & $0.0263(9)$ & $-0.0004(7)$ & $0.0115(8)$ & $0.0011(7)$ \\
C2 & $0.0318(10)$ & $0.0367(10)$ & $0.0383(12)$ & $-0.0059(8)$ & $0.0169(9)$ & $-0.0017(8)$ \\
C3 & $0.0303(11)$ & $0.0357(10)$ & $0.0368(11)$ & $-0.0096(8)$ & $0.0084(9)$ & $-0.0049(9)$ \\
C4 & $0.0337(10)$ & $0.0307(10)$ & $0.0268(10)$ & $-0.0029(8)$ & $0.0053(8)$ & $-0.0036(8)$ \\
C5 & $0.0313(10)$ & $0.0247(8)$ & $0.0233(9)$ & $0.0019(7)$ & $0.0088(8)$ & $0.0016(7)$ \\
C6 & $0.0285(10)$ & $0.0311(9)$ & $0.0247(9)$ & $0.0009(8)$ & $0.0104(8)$ & $0.0003(7)$ \\
C7 & $0.0363(11)$ & $0.0279(9)$ & $0.0257(10)$ & $0.0024(8)$ & $0.0130(8)$ & $0.0000(7)$ \\
C8 & $0.0276(10)$ & $0.0494(12)$ & $0.0220(10)$ & $0.0069(8)$ & $0.0114(8)$ & $0.0034(8)$ \\
C9 & $0.0253(11)$ & $0.0720(15)$ & $0.0267(11)$ & $0.0106(10)$ & $0.0085(9)$ & $0.0009(10)$ \\
C10 & $0.0241(10)$ & $0.0720(16)$ & $0.0396(13)$ & $-0.0077(10)$ & $0.0101(9)$ & $-0.0048(11)$ \\
C11 & $0.0334(11)$ & $0.0515(12)$ & $0.0357(11)$ & $-0.0116(9)$ & $0.0139(9)$ & $-0.0046(10)$ \\
C12 & $0.0262(9)$ & $0.0408(10)$ & $0.0234(9)$ & $-0.0046(8)$ & $0.0109(8)$ & $-0.0020(8)$ \\
C13 & $0.0424(12)$ & $0.0461(12)$ & $0.0352(12)$ & $0.0162(10)$ & $0.0211(10)$ & $0.0094(9)$ \\
& & & & &
\end{tabular}


$\begin{array}{lllllll}\mathrm{C} 14 & 0.0326(10) & 0.0354(10) & 0.0247(9) & -0.0008(8) & 0.0123(8) & -0.0007(8)\end{array}$

Geometric parameters $(\AA, \stackrel{o}{)}$

\begin{tabular}{|c|c|c|c|}
\hline $\mathrm{Ni1}-\mathrm{N} 1$ & $1.9654(15)$ & $\mathrm{O} 11 \mathrm{C}-\mathrm{H} 11 \mathrm{~S}$ & 0.8386 \\
\hline $\mathrm{Ni} 1-\mathrm{N} 2$ & $1.9720(16)$ & $\mathrm{O} 11 \mathrm{C}-\mathrm{H} 11 \mathrm{~T}$ & 0.8308 \\
\hline $\mathrm{Ni1}-\mathrm{O} 1$ & $2.0959(14)$ & $\mathrm{N} 1-\mathrm{C} 1$ & $1.330(2)$ \\
\hline $\mathrm{Ni1}-\mathrm{O} 5$ & $2.1036(14)$ & $\mathrm{N} 1-\mathrm{C} 5$ & $1.335(2)$ \\
\hline $\mathrm{Ni1}-\mathrm{O} 3$ & $2.1666(14)$ & $\mathrm{N} 2-\mathrm{C} 12$ & $1.333(3)$ \\
\hline $\mathrm{Ni1}-\mathrm{O} 7$ & $2.1940(14)$ & $\mathrm{N} 2-\mathrm{C} 8$ & $1.333(3)$ \\
\hline $\mathrm{O} 1-\mathrm{C} 6$ & $1.265(2)$ & $\mathrm{C} 1-\mathrm{C} 2$ & $1.385(3)$ \\
\hline $\mathrm{O} 2-\mathrm{C} 6$ & $1.243(2)$ & $\mathrm{C} 1-\mathrm{C} 6$ & $1.518(3)$ \\
\hline $\mathrm{O} 3-\mathrm{C} 7$ & $1.253(2)$ & $\mathrm{C} 2-\mathrm{C} 3$ & $1.397(3)$ \\
\hline $\mathrm{O} 4-\mathrm{C} 7$ & $1.271(2)$ & $\mathrm{C} 2-\mathrm{H} 2$ & 0.9400 \\
\hline $\mathrm{O} 4-\mathrm{H} 4 \mathrm{O}$ & $0.844(5)$ & $\mathrm{C} 3-\mathrm{C} 4$ & $1.386(3)$ \\
\hline $\mathrm{O} 5-\mathrm{C} 13$ & $1.288(3)$ & $\mathrm{C} 3-\mathrm{H} 3$ & 0.9400 \\
\hline $\mathrm{O} 6-\mathrm{C} 13$ & $1.224(3)$ & $\mathrm{C} 4-\mathrm{C} 5$ & $1.379(3)$ \\
\hline $\mathrm{O} 7-\mathrm{C} 14$ & $1.238(2)$ & $\mathrm{C} 4-\mathrm{H} 4$ & 0.9400 \\
\hline $\mathrm{O} 8-\mathrm{C} 14$ & $1.284(2)$ & $\mathrm{C} 5-\mathrm{C} 7$ & $1.506(3)$ \\
\hline $\mathrm{O} 8-\mathrm{H} 8 \mathrm{O}$ & $0.842(5)$ & $\mathrm{C} 8-\mathrm{C} 9$ & $1.394(3)$ \\
\hline $\mathrm{O} 9-\mathrm{H} 9 \mathrm{O}$ & 0.8401 & $\mathrm{C} 8-\mathrm{C} 13$ & $1.503(3)$ \\
\hline O9-H9P & 0.8400 & $\mathrm{C} 9-\mathrm{C} 10$ & $1.369(4)$ \\
\hline $\mathrm{O} 10-\mathrm{H} 10 \mathrm{O}$ & 0.8400 & $\mathrm{C} 9-\mathrm{H} 9$ & 0.9400 \\
\hline $\mathrm{O} 10-\mathrm{H} 10 \mathrm{P}$ & 0.8400 & $\mathrm{C} 10-\mathrm{C} 11$ & $1.393(3)$ \\
\hline $\mathrm{O} 11 \mathrm{~A}-\mathrm{H} 11 \mathrm{O}$ & 0.8460 & $\mathrm{C} 10-\mathrm{H} 10$ & 0.9400 \\
\hline O11A-H11P & 0.8480 & $\mathrm{C} 11-\mathrm{C} 12$ & $1.380(3)$ \\
\hline $\mathrm{O} 11 \mathrm{~B}-\mathrm{O} 11 \mathrm{~B}^{\mathrm{i}}$ & $1.765(19)$ & C11-H11 & 0.9400 \\
\hline $\mathrm{O} 11 \mathrm{~B}-\mathrm{H} 11 \mathrm{Q}$ & 0.8576 & $\mathrm{C} 12-\mathrm{C} 14$ & $1.500(3)$ \\
\hline $\mathrm{O} 11 \mathrm{~B}-\mathrm{H} 11 \mathrm{R}$ & 0.8316 & & \\
\hline $\mathrm{N} 1-\mathrm{Ni1}-\mathrm{N} 2$ & $176.53(6)$ & $\mathrm{C} 1-\mathrm{C} 2-\mathrm{H} 2$ & 120.8 \\
\hline $\mathrm{N} 1-\mathrm{Ni1}-\mathrm{O} 1$ & $78.84(6)$ & $\mathrm{C} 3-\mathrm{C} 2-\mathrm{H} 2$ & 120.8 \\
\hline $\mathrm{N} 2-\mathrm{Ni} 1-\mathrm{O} 1$ & $104.49(6)$ & $\mathrm{C} 4-\mathrm{C} 3-\mathrm{C} 2$ & $120.05(18)$ \\
\hline $\mathrm{N} 1-\mathrm{Ni1}-\mathrm{O} 5$ & $100.48(6)$ & $\mathrm{C} 4-\mathrm{C} 3-\mathrm{H} 3$ & 120.0 \\
\hline $\mathrm{N} 2-\mathrm{Ni} 1-\mathrm{O} 5$ & $78.52(6)$ & $\mathrm{C} 2-\mathrm{C} 3-\mathrm{H} 3$ & 120.0 \\
\hline $\mathrm{O} 1-\mathrm{Ni} 1-\mathrm{O} 5$ & $92.69(6)$ & $\mathrm{C} 5-\mathrm{C} 4-\mathrm{C} 3$ & $118.05(18)$ \\
\hline $\mathrm{N} 1-\mathrm{Ni1}-\mathrm{O} 3$ & $77.29(6)$ & $\mathrm{C} 5-\mathrm{C} 4-\mathrm{H} 4$ & 121.0 \\
\hline $\mathrm{N} 2-\mathrm{Ni} 1-\mathrm{O} 3$ & $99.40(6)$ & $\mathrm{C} 3-\mathrm{C} 4-\mathrm{H} 4$ & 121.0 \\
\hline $\mathrm{O} 1-\mathrm{Ni1}-\mathrm{O} 3$ & $156.09(6)$ & $\mathrm{N} 1-\mathrm{C} 5-\mathrm{C} 4$ & $121.39(17)$ \\
\hline $\mathrm{O} 5-\mathrm{Ni} 1-\mathrm{O} 3$ & $92.85(6)$ & $\mathrm{N} 1-\mathrm{C} 5-\mathrm{C} 7$ & $111.71(16)$ \\
\hline $\mathrm{N} 1-\mathrm{Ni1}-\mathrm{O} 7$ & $104.37(6)$ & $\mathrm{C} 4-\mathrm{C} 5-\mathrm{C} 7$ & $126.91(17)$ \\
\hline $\mathrm{N} 2-\mathrm{Ni} 1-\mathrm{O} 7$ & $76.60(6)$ & $\mathrm{O} 2-\mathrm{C} 6-\mathrm{O} 1$ & $125.83(18)$ \\
\hline $\mathrm{O} 1-\mathrm{Ni1}-\mathrm{O} 7$ & $93.18(6)$ & $\mathrm{O} 2-\mathrm{C} 6-\mathrm{C} 1$ & $118.45(17)$ \\
\hline $\mathrm{O} 5-\mathrm{Ni} 1-\mathrm{O} 7$ & $155.12(6)$ & $\mathrm{O} 1-\mathrm{C} 6-\mathrm{C} 1$ & $115.72(16)$ \\
\hline $\mathrm{O} 3-\mathrm{Ni1}-\mathrm{O} 7$ & $91.51(6)$ & $\mathrm{O} 3-\mathrm{C} 7-\mathrm{O} 4$ & $126.24(19)$ \\
\hline $\mathrm{C} 6-\mathrm{O} 1-\mathrm{Ni} 1$ & $114.51(12)$ & $\mathrm{O} 3-\mathrm{C} 7-\mathrm{C} 5$ & $117.68(16)$ \\
\hline $\mathrm{C} 7-\mathrm{O} 3-\mathrm{Ni} 1$ & $113.04(12)$ & $\mathrm{O} 4-\mathrm{C} 7-\mathrm{C} 5$ & $116.08(17)$ \\
\hline $\mathrm{C} 7-\mathrm{O} 4-\mathrm{H} 4 \mathrm{O}$ & $119(2)$ & $\mathrm{N} 2-\mathrm{C} 8-\mathrm{C} 9$ & $120.4(2)$ \\
\hline
\end{tabular}




\begin{tabular}{|c|c|c|c|}
\hline $\mathrm{C} 13-\mathrm{O} 5-\mathrm{Ni} 1$ & $114.88(13)$ & $\mathrm{N} 2-\mathrm{C} 8-\mathrm{C} 13$ & $113.91(18)$ \\
\hline $\mathrm{C} 14-\mathrm{O} 7-\mathrm{Ni1}$ & $112.34(12)$ & $\mathrm{C} 9-\mathrm{C} 8-\mathrm{C} 13$ & $125.7(2)$ \\
\hline $\mathrm{C} 14-\mathrm{O} 8-\mathrm{H} 8 \mathrm{O}$ & $112(2)$ & $\mathrm{C} 10-\mathrm{C} 9-\mathrm{C} 8$ & $118.8(2)$ \\
\hline $\mathrm{H} 9 \mathrm{O}-\mathrm{O} 9-\mathrm{H} 9 \mathrm{P}$ & 102.4 & $\mathrm{C} 10-\mathrm{C} 9-\mathrm{H} 9$ & 120.6 \\
\hline $\mathrm{H} 10 \mathrm{O}-\mathrm{O} 10-\mathrm{H} 10 \mathrm{P}$ & 103.0 & $\mathrm{C} 8-\mathrm{C} 9-\mathrm{H} 9$ & 120.6 \\
\hline $\mathrm{H} 11 \mathrm{O}-\mathrm{O} 11 \mathrm{~A}-\mathrm{H} 11 \mathrm{P}$ & 113.0 & $\mathrm{C} 9-\mathrm{C} 10-\mathrm{C} 11$ & $120.4(2)$ \\
\hline $\mathrm{O} 11 \mathrm{~B}-\mathrm{O} 11 \mathrm{~B}-\mathrm{H} 11 \mathrm{Q}$ & 84.6 & $\mathrm{C} 9-\mathrm{C} 10-\mathrm{H} 10$ & 119.8 \\
\hline $\mathrm{O} 11 \mathrm{~B}-\mathrm{O} 11 \mathrm{~B}-\mathrm{H} 11 \mathrm{R}$ & 42.2 & $\mathrm{C} 11-\mathrm{C} 10-\mathrm{H} 10$ & 119.8 \\
\hline $\mathrm{H} 11 \mathrm{Q}-\mathrm{O} 11 \mathrm{~B}-\mathrm{H} 11 \mathrm{R}$ & 126.8 & $\mathrm{C} 12-\mathrm{C} 11-\mathrm{C} 10$ & $117.8(2)$ \\
\hline $\mathrm{H} 11 \mathrm{~S}-\mathrm{O} 11 \mathrm{C}-\mathrm{H} 11 \mathrm{~T}$ & 128.7 & $\mathrm{C} 12-\mathrm{C} 11-\mathrm{H} 11$ & 121.1 \\
\hline $\mathrm{C} 1-\mathrm{N} 1-\mathrm{C} 5$ & $121.50(16)$ & $\mathrm{C} 10-\mathrm{C} 11-\mathrm{H} 11$ & 121.1 \\
\hline $\mathrm{C} 1-\mathrm{N} 1-\mathrm{Ni} 1$ & $118.22(13)$ & $\mathrm{N} 2-\mathrm{C} 12-\mathrm{C} 11$ & $121.53(19)$ \\
\hline $\mathrm{C} 5-\mathrm{N} 1-\mathrm{Ni} 1$ & $120.13(12)$ & $\mathrm{N} 2-\mathrm{C} 12-\mathrm{C} 14$ & $111.21(16)$ \\
\hline $\mathrm{C} 12-\mathrm{N} 2-\mathrm{C} 8$ & $121.16(17)$ & $\mathrm{C} 11-\mathrm{C} 12-\mathrm{C} 14$ & $127.26(19)$ \\
\hline $\mathrm{C} 12-\mathrm{N} 2-\mathrm{Ni} 1$ & $120.80(13)$ & $\mathrm{O} 6-\mathrm{C} 13-\mathrm{O} 5$ & $126.3(2)$ \\
\hline $\mathrm{C} 8-\mathrm{N} 2-\mathrm{Ni} 1$ & $118.03(14)$ & $\mathrm{O} 6-\mathrm{C} 13-\mathrm{C} 8$ & $119.0(2)$ \\
\hline $\mathrm{N} 1-\mathrm{C} 1-\mathrm{C} 2$ & $120.67(17)$ & $\mathrm{O} 5-\mathrm{C} 13-\mathrm{C} 8$ & $114.65(18)$ \\
\hline $\mathrm{N} 1-\mathrm{C} 1-\mathrm{C} 6$ & $112.57(16)$ & $\mathrm{O} 7-\mathrm{C} 14-\mathrm{O} 8$ & $125.42(18)$ \\
\hline $\mathrm{C} 2-\mathrm{C} 1-\mathrm{C} 6$ & $126.76(17)$ & $\mathrm{O} 7-\mathrm{C} 14-\mathrm{C} 12$ & $119.01(17)$ \\
\hline $\mathrm{C} 1-\mathrm{C} 2-\mathrm{C} 3$ & $118.33(18)$ & $\mathrm{O} 8-\mathrm{C} 14-\mathrm{C} 12$ & $115.57(17)$ \\
\hline
\end{tabular}

Symmetry code: (i) $-x+1,-y+2,-z$.

Hydrogen-bond geometry $\left(\AA,{ }^{\circ}\right)$

\begin{tabular}{lllll}
\hline$D-\mathrm{H} \cdots A$ & $D-\mathrm{H}$ & $\mathrm{H} \cdots A$ & $D \cdots A$ & $D-\mathrm{H} \cdots A$ \\
\hline $\mathrm{O} 4-\mathrm{H} 4 O \cdots \mathrm{O} 10^{\mathrm{ii}}$ & $0.84(1)$ & $1.61(1)$ & $2.456(2)$ & $177(3)$ \\
$\mathrm{O} 8-\mathrm{H} 8 O \cdots \mathrm{O} 9^{\mathrm{iii}}$ & $0.84(1)$ & $1.63(1)$ & $2.462(2)$ & $171(3)$ \\
$\mathrm{O} 9-\mathrm{H} 9 O \cdots \mathrm{O} 2^{\mathrm{iv}}$ & 0.84 & 1.94 & $2.751(2)$ & 162 \\
$\mathrm{O} 9-\mathrm{H} 9 P \cdots \mathrm{O} 2^{\mathrm{ii}}$ & 0.84 & 1.84 & $2.678(2)$ & 172 \\
$\mathrm{O} 10-\mathrm{H} 10 O \cdots \mathrm{O} 11 A^{\mathrm{v}}$ & 0.84 & 1.90 & $2.529(5)$ & 131 \\
$\mathrm{O} 10-\mathrm{H} 10 O \cdots \mathrm{O} 11 B^{\mathrm{v}}$ & 0.84 & 1.89 & $2.715(8)$ & 166 \\
$\mathrm{O} 10-\mathrm{H} 10 O \cdots \mathrm{O} 11 C^{\mathrm{v}}$ & 0.84 & 1.86 & $2.581(7)$ & 143 \\
$\mathrm{O} 10-\mathrm{H} 10 P \cdots \mathrm{O} 5$ & 0.84 & 1.78 & $2.608(2)$ & 167 \\
$\mathrm{O} 11 A-\mathrm{H} 11 P \cdots \mathrm{O} 3$ & 0.85 & 2.08 & $2.842(5)$ & 149 \\
$\mathrm{O} 11 C-\mathrm{H} 11 T \cdots \mathrm{O} 3$ & 0.83 & 2.11 & $2.798(8)$ & 140 \\
$\mathrm{C} 2-\mathrm{H} 2 \cdots \mathrm{O} 7^{\mathrm{iv}}$ & 0.94 & 2.65 & $3.528(2)$ & 155 \\
$\mathrm{C} 4-\mathrm{H} 4 \cdots \mathrm{O} 7^{\mathrm{vi}}$ & 0.94 & 2.51 & $3.195(2)$ & 130 \\
$\mathrm{C} 9-\mathrm{H} 9 \cdots{ }^{\mathrm{vii}}$ & 0.94 & 2.55 & $3.275(3)$ & 135 \\
\hline
\end{tabular}

Symmetry codes: (ii) $x,-y+3 / 2, z-1 / 2$; (iii) $x, y+1, z$; (iv) $-x, y-1 / 2,-z+1 / 2$; (v) $x,-y+3 / 2, z+1 / 2$; (vi) $-x,-y+2,-z$; (vii) $-x+1,-y+2,-z+1$.

Poly[(4-chloropyridine-2,6-dicarboxylato)zinc(II)] (3)

Crystal data

$\left[\mathrm{Zn}\left(\mathrm{C}_{7} \mathrm{H}_{2} \mathrm{ClNO}_{4}\right)\right]$

$M_{r}=264.94$

Tetragonal, $P \overline{4}{ }_{2} c$ $a=10.0293(5) \AA$

$c=16.8924(9) \AA$

$$
\begin{aligned}
& V=1699.15(19) \AA^{3} \\
& Z=8 \\
& F(000)=1040 \\
& D_{\mathrm{x}}=2.071 \mathrm{Mg} \mathrm{m}^{-3}
\end{aligned}
$$

Mo $K \alpha$ radiation, $\lambda=0.71073 \AA$ 
Cell parameters from 2678 reflections

$\theta=2.4-26.4^{\circ}$

$\mu=3.19 \mathrm{~mm}^{-1}$

\section{Data collection}

Bruker APEX CCD

diffractometer

Radiation source: microsource

Multilayer optics monochromator

$\omega$ scans

Absorption correction: multi-scan

SADABS (Bruker, 2008)

$T_{\min }=0.590, T_{\max }=0.746$

Refinement

Refinement on $F^{2}$

Least-squares matrix: full

$R\left[F^{2}>2 \sigma\left(F^{2}\right)\right]=0.026$

$w R\left(F^{2}\right)=0.064$

$S=1.07$

2592 reflections

128 parameters

0 restraints
$T=100 \mathrm{~K}$

Block, colourless

$0.25 \times 0.10 \times 0.10 \mathrm{~mm}$

25321 measured reflections

2592 independent reflections

2266 reflections with $I>2 \sigma(I)$

$R_{\text {int }}=0.059$

$\theta_{\max }=30.7^{\circ}, \theta_{\min }=2.4^{\circ}$

$h=-13 \rightarrow 14$

$k=-14 \rightarrow 14$

$l=-24 \rightarrow 24$

Hydrogen site location: inferred from neighbouring sites

$\mathrm{H}$-atom parameters constrained

$w=1 /\left[\sigma^{2}\left(F_{\mathrm{o}}^{2}\right)+(0.0248 P)^{2}+0.4106 P\right]$

where $P=\left(F_{\mathrm{o}}^{2}+2 F_{\mathrm{c}}{ }^{2}\right) / 3$

$(\Delta / \sigma)_{\max }=0.001$

$\Delta \rho_{\max }=0.42 \mathrm{e} \AA^{-3}$

$\Delta \rho_{\min }=-0.31$ e $\AA^{-3}$

Absolute structure: Refined as an inversion twin

Absolute structure parameter: 0.41 (2)

\section{Special details}

Geometry. All esds (except the esd in the dihedral angle between two 1.s. planes) are estimated using the full covariance matrix. The cell esds are taken into account individually in the estimation of esds in distances, angles and torsion angles; correlations between esds in cell parameters are only used when they are defined by crystal symmetry. An approximate (isotropic) treatment of cell esds is used for estimating esds involving 1.s. planes.

Refinement. Refined as a 2-component inversion twin.

Fractional atomic coordinates and isotropic or equivalent isotropic displacement parameters $\left(\AA^{2}\right)$

\begin{tabular}{lllll}
\hline & $x$ & $y$ & $z$ & $U_{\text {iso }} / U_{\text {eq }}$ \\
\hline Zn1 & $0.73303(4)$ & $0.76705(4)$ & $0.46958(2)$ & $0.01131(10)$ \\
C11 & $0.73595(8)$ & $0.52181(7)$ & $0.82114(4)$ & $0.01753(16)$ \\
O1 & $0.9441(2)$ & $0.7594(2)$ & $0.49968(12)$ & $0.0137(4)$ \\
O2 & $1.0803(2)$ & $0.7124(2)$ & $0.60091(13)$ & $0.0148(5)$ \\
O3 & $0.5199(2)$ & $0.7649(2)$ & $0.50370(12)$ & $0.0169(5)$ \\
O4 & $0.3846(2)$ & $0.7135(2)$ & $0.60504(13)$ & $0.0154(5)$ \\
N1 & $0.7328(3)$ & $0.7259(2)$ & $0.58750(13)$ & $0.0109(4)$ \\
C1 & $0.8485(3)$ & $0.6968(3)$ & $0.62164(18)$ & $0.0104(6)$ \\
C2 & $0.8556(3)$ & $0.6374(3)$ & $0.69606(18)$ & $0.0127(6)$ \\
H2 & 0.9387 & 0.6182 & 0.7206 & $0.015^{*}$ \\
C3 & $0.7347(3)$ & $0.6073(3)$ & $0.73287(16)$ & $0.0130(6)$ \\
C4 & $0.6137(3)$ & $0.6418(3)$ & $0.69826(18)$ & $0.0132(6)$ \\
H4 & 0.5314 & 0.6260 & 0.7245 & $0.016^{*}$ \\
C5 & $0.6181(3)$ & $0.7001(3)$ & $0.62380(19)$ & $0.0123(6)$ \\
C6 & $0.9667(3)$ & $0.7258(4)$ & $0.56939(16)$ & $0.0115(6)$
\end{tabular}




\begin{tabular}{|c|c|c|c|c|}
\hline $\mathrm{C} 7$ & 0.4968 & $0.7298(4)$ & $0.57322(16)$ & $0.0128(6)$ \\
\hline
\end{tabular}

Atomic displacement parameters $\left(\AA^{2}\right)$

\begin{tabular}{lllllll}
\hline & $U^{11}$ & $U^{22}$ & $U^{33}$ & $U^{12}$ & $U^{13}$ & $U^{23}$ \\
\hline Zn1 & $0.01409(17)$ & $0.01086(16)$ & $0.00897(16)$ & $-0.00018(11)$ & $-0.00130(12)$ & $0.00069(12)$ \\
C11 & $0.0218(4)$ & $0.0193(3)$ & $0.0115(3)$ & $-0.0007(3)$ & $0.0004(3)$ & $0.0054(3)$ \\
O1 & $0.0140(10)$ & $0.0172(12)$ & $0.0098(9)$ & $0.0002(9)$ & $0.0008(8)$ & $0.0012(9)$ \\
O2 & $0.0097(10)$ & $0.0218(12)$ & $0.0129(10)$ & $0.0015(9)$ & $0.0004(8)$ & $0.0013(10)$ \\
O3 & $0.0125(10)$ & $0.0251(13)$ & $0.0131(9)$ & $0.0007(10)$ & $-0.0010(8)$ & $0.0042(10)$ \\
O4 & $0.0108(10)$ & $0.0193(12)$ & $0.0162(11)$ & $0.0014(9)$ & $0.0004(8)$ & $0.0027(10)$ \\
N1 & $0.0109(10)$ & $0.0113(10)$ & $0.0104(10)$ & $-0.0015(11)$ & $0.0006(9)$ & $-0.0025(9)$ \\
C1 & $0.0102(13)$ & $0.0110(15)$ & $0.0100(14)$ & $-0.0015(10)$ & $0.0007(11)$ & $-0.0012(11)$ \\
C2 & $0.0117(14)$ & $0.0145(15)$ & $0.0120(16)$ & $0.0005(11)$ & $-0.0021(11)$ & $0.0016(12)$ \\
C3 & $0.0182(15)$ & $0.0128(13)$ & $0.0079(12)$ & $0.0010(12)$ & $-0.0010(12)$ & $0.0005(10)$ \\
C4 & $0.0139(15)$ & $0.0139(15)$ & $0.0118(15)$ & $-0.0026(11)$ & $0.0022(11)$ & $-0.0016(12)$ \\
C5 & $0.0121(14)$ & $0.0111(16)$ & $0.0138(15)$ & $-0.0009(11)$ & $-0.0013(11)$ & $-0.0020(12)$ \\
C6 & $0.0100(13)$ & $0.0123(14)$ & $0.0120(14)$ & $-0.0005(13)$ & $0.0012(10)$ & $-0.0033(11)$ \\
C7 & $0.0121(14)$ & $0.0121(14)$ & $0.0141(13)$ & $0.0008(13)$ & $-0.0020(10)$ & $-0.0013(12)$ \\
& & & & & &
\end{tabular}

Geometric parameters $(\AA, \circ)$

\begin{tabular}{|c|c|c|c|}
\hline $\mathrm{Zn} 1-\mathrm{O} 2^{\mathrm{i}}$ & $1.950(2)$ & $\mathrm{O} 4-\mathrm{Zn} 1^{\mathrm{iv}}$ & $1.985(2)$ \\
\hline $\mathrm{Zn} 1-\mathrm{O} 4^{\mathrm{ii}}$ & $1.985(2)$ & $\mathrm{N} 1-\mathrm{C} 1$ & $1.329(4)$ \\
\hline $\mathrm{Zn} 1-\mathrm{N} 1$ & $2.034(2)$ & $\mathrm{N} 1-\mathrm{C} 5$ & $1.329(4)$ \\
\hline $\mathrm{Zn} 1-\mathrm{O} 1$ & $2.178(2)$ & $\mathrm{C} 1-\mathrm{C} 2$ & $1.393(4)$ \\
\hline $\mathrm{Zn} 1-\mathrm{O} 3$ & $2.214(2)$ & $\mathrm{C} 1-\mathrm{C} 6$ & $1.506(4)$ \\
\hline $\mathrm{C} 11-\mathrm{C} 3$ & $1.720(3)$ & $\mathrm{C} 2-\mathrm{C} 3$ & $1.395(4)$ \\
\hline $\mathrm{O} 1-\mathrm{C} 6$ & $1.246(3)$ & $\mathrm{C} 2-\mathrm{H} 2$ & 0.9500 \\
\hline $\mathrm{O} 2-\mathrm{C} 6$ & $1.265(4)$ & $\mathrm{C} 3-\mathrm{C} 4$ & $1.391(5)$ \\
\hline $\mathrm{O} 2-\mathrm{Zn} 1^{\mathrm{iii}}$ & $1.950(2)$ & $\mathrm{C} 4-\mathrm{C} 5$ & $1.388(4)$ \\
\hline $\mathrm{O} 3-\mathrm{C} 7$ & $1.247(3)$ & $\mathrm{C} 4-\mathrm{H} 4$ & 0.9500 \\
\hline $\mathrm{O} 4-\mathrm{C} 7$ & $1.259(4)$ & $\mathrm{C} 5-\mathrm{C} 7$ & $1.516(4)$ \\
\hline $\mathrm{O} 2^{\mathrm{i}}-\mathrm{Zn} 1-\mathrm{O} 4^{\mathrm{ii}}$ & $101.71(8)$ & $\mathrm{C} 2-\mathrm{C} 1-\mathrm{C} 6$ & $124.8(3)$ \\
\hline $\mathrm{O} 2 \mathrm{i}-\mathrm{Zn} 1-\mathrm{N} 1$ & $139.20(10)$ & $\mathrm{C} 1-\mathrm{C} 2-\mathrm{C} 3$ & $116.8(3)$ \\
\hline $\mathrm{O} 4^{\mathrm{ii}}-\mathrm{Zn} 1-\mathrm{N} 1$ & $117.79(9)$ & $\mathrm{C} 1-\mathrm{C} 2-\mathrm{H} 2$ & 121.6 \\
\hline $\mathrm{O} 2^{\mathrm{i}}-\mathrm{Zn} 1-\mathrm{O} 1$ & $105.86(9)$ & $\mathrm{C} 3-\mathrm{C} 2-\mathrm{H} 2$ & 121.6 \\
\hline $\mathrm{O} 4^{\mathrm{ii}}-\mathrm{Zn} 1-\mathrm{O} 1$ & $102.54(9)$ & $\mathrm{C} 4-\mathrm{C} 3-\mathrm{C} 2$ & $121.1(3)$ \\
\hline $\mathrm{N} 1-\mathrm{Zn} 1-\mathrm{O} 1$ & $76.44(9)$ & $\mathrm{C} 4-\mathrm{C} 3-\mathrm{Cl1}$ & $119.6(2)$ \\
\hline $\mathrm{O} 2 \mathrm{i}-\mathrm{Zn} 1-\mathrm{O} 3$ & $93.68(9)$ & $\mathrm{C} 2-\mathrm{C} 3-\mathrm{Cl} 1$ & $119.2(2)$ \\
\hline 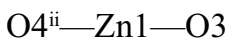 & $93.58(9)$ & $\mathrm{C} 5-\mathrm{C} 4-\mathrm{C} 3$ & $117.2(3)$ \\
\hline $\mathrm{N} 1-\mathrm{Zn} 1-\mathrm{O} 3$ & $75.04(9)$ & $\mathrm{C} 5-\mathrm{C} 4-\mathrm{H} 4$ & 121.4 \\
\hline $\mathrm{O} 1-\mathrm{Zn} 1-\mathrm{O} 3$ & $151.30(7)$ & $\mathrm{C} 3-\mathrm{C} 4-\mathrm{H} 4$ & 121.4 \\
\hline $\mathrm{C} 6-\mathrm{O} 1-\mathrm{Zn} 1$ & $114.03(18)$ & $\mathrm{N} 1-\mathrm{C} 5-\mathrm{C} 4$ & $121.9(3)$ \\
\hline $\mathrm{C} 6-\mathrm{O} 2-\mathrm{Zn} 1^{\mathrm{iii}}$ & $116.01(18)$ & $\mathrm{N} 1-\mathrm{C} 5-\mathrm{C} 7$ & $113.3(3)$ \\
\hline $\mathrm{C} 7-\mathrm{O} 3-\mathrm{Zn} 1$ & $115.3(2)$ & $\mathrm{C} 4-\mathrm{C} 5-\mathrm{C} 7$ & $124.6(3)$ \\
\hline $\mathrm{C} 7-\mathrm{O} 4-\mathrm{Zn} 1^{\mathrm{iv}}$ & $113.67(19)$ & $\mathrm{O} 1-\mathrm{C} 6-\mathrm{O} 2$ & $126.2(3)$ \\
\hline
\end{tabular}




$\begin{array}{llll}\mathrm{C} 1-\mathrm{N} 1-\mathrm{C} 5 & 120.9(2) & \mathrm{O} 1-\mathrm{C} 6-\mathrm{C} 1 & 117.6(3) \\ \mathrm{C} 1-\mathrm{N} 1-\mathrm{Zn} 1 & 117.93(19) & \mathrm{O} 2-\mathrm{C} 6-\mathrm{C} 1 & 116.2(3) \\ \mathrm{C} 5-\mathrm{N} 1-\mathrm{Zn} 1 & 119.5(2) & \mathrm{O} 3-\mathrm{C} 7-\mathrm{O} 4 & 127.2(3) \\ \mathrm{N} 1-\mathrm{C} 1-\mathrm{C} 2 & 122.0(3) & \mathrm{O} 3-\mathrm{C} 7-\mathrm{C} 5 & 115.9(3) \\ \mathrm{N} 1-\mathrm{C} 1-\mathrm{C} 6 & 113.0(3) & \mathrm{O} 4-\mathrm{C} 7-\mathrm{C} 5 & 116.8(3) \\ & & & \\ \mathrm{C} 5-\mathrm{N} 1-\mathrm{C} 1-\mathrm{C} 2 & 0.6(4) & \mathrm{Zn} 1-\mathrm{O} 1-\mathrm{C} 6-\mathrm{O} 2 & -0.3(4) \\ \mathrm{Zn} 1-\mathrm{N} 1-\mathrm{C} 1-\mathrm{C} 2 & -164.5(2) & \mathrm{Zn} 1-\mathrm{O} 1-\mathrm{C} 6-\mathrm{C} 1 & -5.2(5) \\ \mathrm{C} 5-\mathrm{N} 1-\mathrm{C} 1-\mathrm{C} 6 & 176.6(3) & \mathrm{Zn} 1 \mathrm{iii}-\mathrm{O} 2-\mathrm{C} 6-\mathrm{C} 1 & 174.2(2) \\ \mathrm{Zn} 1-\mathrm{N} 1-\mathrm{C} 1-\mathrm{C} 6 & 11.4(4) & \mathrm{N} 1-\mathrm{C} 1-\mathrm{C} 6-\mathrm{O} 1 & -7.0(5) \\ \mathrm{N} 1-\mathrm{C} 1-\mathrm{C} 2-\mathrm{C} 3 & 1.1(5) & \mathrm{N} 1-\mathrm{C} 1-\mathrm{C} 6-\mathrm{O} 2 & 168.8(3) \\ \mathrm{C} 6-\mathrm{C} 1-\mathrm{C} 2-\mathrm{C} 3 & -174.4(3) & \mathrm{C} 2-\mathrm{C} 1-\mathrm{C} 6-\mathrm{O} 2 & 173.5(3) \\ \mathrm{C} 1-\mathrm{C} 2-\mathrm{C} 3-\mathrm{C} 4 & -3.2(4) & \mathrm{Zn} 1-\mathrm{O} 3-\mathrm{C} 7-\mathrm{O} 4 & -10.7(5) \\ \mathrm{C} 1-\mathrm{C} 2-\mathrm{C} 3-\mathrm{C} 11 & 174.8(2) & \mathrm{Zn} 1-\mathrm{O} 3-\mathrm{C} 7-\mathrm{C} 5 & 2.4(4) \\ \mathrm{C} 2-\mathrm{C} 3-\mathrm{C} 4-\mathrm{C} 5 & 3.6(4) & \mathrm{Zn} 1{ }^{\mathrm{iv}}-\mathrm{O} 4-\mathrm{C} 7-\mathrm{O} 3 & 5.3(5) \\ \mathrm{C} 11-\mathrm{C} 3-\mathrm{C} 4-\mathrm{C} 5 & -174.4(2) & \mathrm{Zn} 1-\mathrm{O} 4-\mathrm{C} 7-\mathrm{C} 5 & -172.8(2) \\ \mathrm{C} 1-\mathrm{N} 1-\mathrm{C} 5-\mathrm{C} 4 & -0.2(4) & \mathrm{C} 4-\mathrm{C} 5-\mathrm{C} 5-\mathrm{C} 7-\mathrm{O} 3 & 4.8(4) \\ \mathrm{Zn} 1-\mathrm{N} 1-\mathrm{C} 5-\mathrm{C} 4 & 164.7(2) & \mathrm{N} 1-\mathrm{C} 5-\mathrm{C} 7-\mathrm{O} 4 & -170.2(3) \\ \mathrm{C} 1-\mathrm{N} 1-\mathrm{C} 5-\mathrm{C} 7 & -175.4(3) & \mathrm{C} 4-\mathrm{C} 5-\mathrm{C} 7-\mathrm{O} 4 & -176.9(3) \\ \mathrm{Zn} 1-\mathrm{N} 1-\mathrm{C} 5-\mathrm{C} 7 & -10.5(3) & & 8.1(5) \\ \mathrm{C} 3-\mathrm{C} 4-\mathrm{C} 5-\mathrm{N} 1 & -1.9(5) & & \\ \mathrm{C} 3-\mathrm{C} 4-\mathrm{C} 5-\mathrm{C} 7 & 172.8(3) & & \end{array}$

Symmetry codes: (i) $y,-x+2,-z+1$; (ii) $y,-x+1,-z+1$; (iii) $-y+2, x,-z+1$; (iv) $-y+1, x,-z+1$.

Poly[[(4-hydroxypyridine-2,6-dicarboxylato)zinc(II)] monohydrate] (4)

Crystal data

$\left[\mathrm{Zn}\left(\mathrm{C}_{7} \mathrm{H}_{3} \mathrm{NO}_{5}\right)\right] \cdot \mathrm{H}_{2} \mathrm{O}$

$M_{r}=529.02$

Tetragonal, $P \overline{4} 2_{1} c$

$a=10.050(1) \AA$

$c=16.5060(16) \AA$

$V=1667.1(4) \AA^{3}$

$Z=4$

$F(000)=1056$

Data collection

Bruker APEX CCD

diffractometer

Radiation source: microsource

Multilayer optics monochromator

$\omega$ scans

Absorption correction: multi-scan

SADABS (Bruker, 2008)

$T_{\min }=0.497, T_{\max }=0.746$

Refinement

Refinement on $F^{2}$

Least-squares matrix: full

$R\left[F^{2}>2 \sigma\left(F^{2}\right)\right]=0.033$

$w R\left(F^{2}\right)=0.079$
$D_{\mathrm{x}}=2.108 \mathrm{Mg} \mathrm{m}^{-3}$

Mo $K \alpha$ radiation, $\lambda=0.71073 \AA$

Cell parameters from 5895 reflections

$\theta=2.4-27.0^{\circ}$

$\mu=2.96 \mathrm{~mm}^{-1}$

$T=100 \mathrm{~K}$

Block, brown

$0.16 \times 0.10 \times 0.09 \mathrm{~mm}$

24393 measured reflections

2567 independent reflections

2371 reflections with $I>2 \sigma(I)$

$R_{\text {int }}=0.047$

$\theta_{\text {max }}=30.9^{\circ}, \theta_{\min }=2.4^{\circ}$

$h=-14 \rightarrow 14$

$k=-14 \rightarrow 13$

$l=-22 \rightarrow 23$

$S=1.07$

2567 reflections

141 parameters

1 restraint 
Hydrogen site location: mixed

$\mathrm{H}$ atoms treated by a mixture of independent and constrained refinement

$w=1 /\left[\sigma^{2}\left(F_{\mathrm{o}}^{2}\right)+(0.0285 P)^{2}+3.4402 P\right]$

where $P=\left(F_{\mathrm{o}}^{2}+2 F_{\mathrm{c}}^{2}\right) / 3$
$(\Delta / \sigma)_{\max }=0.001$

$\Delta \rho_{\max }=0.70$ e $\AA^{-3}$

$\Delta \rho_{\text {min }}=-0.46$ e $\AA^{-3}$

Absolute structure: Refined as an inversion twin

Absolute structure parameter: 0.47 (2)

Special details

Geometry. All esds (except the esd in the dihedral angle between two 1.s. planes) are estimated using the full covariance matrix. The cell esds are taken into account individually in the estimation of esds in distances, angles and torsion angles; correlations between esds in cell parameters are only used when they are defined by crystal symmetry. An approximate (isotropic) treatment of cell esds is used for estimating esds involving l.s. planes.

Refinement. Refined as a 2-component inversion twin.

Fractional atomic coordinates and isotropic or equivalent isotropic displacement parameters $\left(\AA^{2}\right)$

\begin{tabular}{llllll}
\hline & $x$ & $y$ & $z$ & $U_{\text {iso }} * U_{\text {eq }}$ & Occ. $(<1)$ \\
\hline Zn1 & $0.72241(4)$ & $0.76135(4)$ & $0.46967(3)$ & $0.01217(11)$ & \\
O1 & $0.9408(3)$ & $0.7580(3)$ & $0.49661(16)$ & $0.0159(6)$ & \\
O2 & $1.0797(3)$ & $0.7043(3)$ & $0.59777(18)$ & $0.0152(6)$ & \\
O3 & $0.5160(3)$ & $0.7585(3)$ & $0.50699(16)$ & $0.0174(6)$ & \\
O4 & $0.3840(3)$ & $0.7027(3)$ & $0.61104(18)$ & $0.0155(6)$ & \\
O5 & $0.7472(3)$ & $0.5500(3)$ & $0.81395(18)$ & $0.0212(6)$ & \\
H5O & $0.671(3)$ & $0.536(6)$ & $0.830(4)$ & $0.032^{*}$ & \\
O6 & 1.0000 & 0.5000 & $0.8756(3)$ & $0.0222(10)$ & \\
H6P & 1.0783 & 0.4849 & 0.8604 & $0.027^{*}$ & \\
O7 & 0.5000 & 0.5000 & $0.8808(3)$ & $0.0368(14)$ & \\
H7A & 0.5132 & 0.4348 & 0.9116 & $0.044^{*}$ & \\
H7B & 0.4868 & 0.5652 & 0.9116 & $0.044^{*}$ & \\
N1 & $0.7320(3)$ & $0.7229(3)$ & $0.58928(19)$ & $0.0134(6)$ & \\
C1 & $0.8490(4)$ & $0.6960(4)$ & $0.6229(3)$ & $0.0136(7)$ & \\
C2 & $0.8598(4)$ & $0.6405(4)$ & $0.6996(3)$ & $0.0156(8)$ & \\
H2 & 0.9444 & 0.6236 & 0.7231 & $0.019^{*}$ & \\
C3 & $0.7419(4)$ & $0.6101(4)$ & $0.7413(2)$ & $0.0151(7)$ & \\
C4 & $0.6192(4)$ & $0.6406(4)$ & $0.7060(3)$ & $0.0148(8)$ & \\
H4 & 0.5382 & 0.6241 & 0.7338 & $0.018^{*}$ & \\
C5 & $0.6198(4)$ & $0.6958(4)$ & $0.6292(3)$ & $0.0142(7)$ & \\
C6 & $0.9661(4)$ & $0.7214(4)$ & $0.5678(2)$ & $0.0131(7)$ & \\
C7 & $0.4964(4)$ & $0.7222(4)$ & $0.5787(2)$ & $0.0133(7)$ & \\
& & & & & \\
\hline
\end{tabular}

Atomic displacement parameters $\left(\AA^{2}\right)$

\begin{tabular}{lllllll}
\hline & $U^{11}$ & $U^{22}$ & $U^{33}$ & $U^{12}$ & $U^{13}$ & $U^{23}$ \\
\hline Zn1 & $0.0140(2)$ & $0.00984(19)$ & $0.01268(18)$ & $-0.00055(14)$ & $-0.00052(16)$ & $0.00011(16)$ \\
O1 & $0.0134(12)$ & $0.0201(16)$ & $0.0143(12)$ & $-0.0001(11)$ & $-0.0004(9)$ & $0.0031(12)$ \\
O2 & $0.0103(12)$ & $0.0185(15)$ & $0.0168(13)$ & $0.0002(10)$ & $0.0004(10)$ & $0.0012(12)$ \\
O3 & $0.0148(12)$ & $0.0223(16)$ & $0.0152(12)$ & $0.0005(11)$ & $-0.0014(9)$ & $0.0027(12)$ \\
O4 & $0.0110(12)$ & $0.0183(15)$ & $0.0171(14)$ & $-0.0003(10)$ & $0.0008(10)$ & $0.0002(11)$ \\
O5 & $0.0140(14)$ & $0.0294(15)$ & $0.0203(14)$ & $-0.0017(12)$ & $-0.0021(12)$ & $0.0113(11)$ \\
O6 & $0.021(2)$ & $0.023(3)$ & $0.023(2)$ & $0.0016(17)$ & 0.000 & 0.000
\end{tabular}


supporting information

\begin{tabular}{lllllll} 
O7 & $0.071(5)$ & $0.020(3)$ & $0.019(2)$ & $-0.014(3)$ & 0.000 & 0.000 \\
N1 & $0.0120(13)$ & $0.0099(13)$ & $0.0183(14)$ & $-0.0008(13)$ & $-0.0015(11)$ & $-0.0003(11)$ \\
C1 & $0.0099(16)$ & $0.0137(19)$ & $0.0174(19)$ & $-0.0005(13)$ & $-0.0020(14)$ & $-0.0011(15)$ \\
C2 & $0.0098(18)$ & $0.019(2)$ & $0.018(2)$ & $0.0002(13)$ & $-0.0018(15)$ & $-0.0006(16)$ \\
C3 & $0.0139(18)$ & $0.0159(17)$ & $0.0156(16)$ & $0.0005(14)$ & $0.0011(15)$ & $0.0009(13)$ \\
C4 & $0.0127(18)$ & $0.0146(19)$ & $0.0172(19)$ & $0.0010(13)$ & $0.0008(14)$ & $0.0011(15)$ \\
C5 & $0.0123(17)$ & $0.0140(18)$ & $0.0165(19)$ & $0.0011(13)$ & $-0.0022(14)$ & $-0.0012(15)$ \\
C6 & $0.0114(16)$ & $0.0106(18)$ & $0.0174(17)$ & $0.0020(14)$ & $-0.0006(13)$ & $-0.0019(15)$ \\
C7 & $0.0140(16)$ & $0.0112(18)$ & $0.0147(17)$ & $0.0007(14)$ & $0.0013(13)$ & $-0.0009(15)$ \\
\hline
\end{tabular}

Geometric parameters $\left(A,{ }^{\circ}\right)$

\begin{tabular}{|c|c|c|c|}
\hline $\mathrm{Zn} 1-\mathrm{O} 2^{\mathrm{i}}$ & $1.956(3)$ & O6-H6P & 0.8400 \\
\hline $\mathrm{Zn} 1-\mathrm{O} 4^{\mathrm{ii}}$ & $1.987(3)$ & $\mathrm{O} 7-\mathrm{H} 7 \mathrm{~A}$ & 0.8400 \\
\hline $\mathrm{Zn} 1-\mathrm{N} 1$ & $2.014(3)$ & $\mathrm{O} 7-\mathrm{H} 7 \mathrm{~B}$ & 0.8400 \\
\hline $\mathrm{Zn} 1-\mathrm{O} 3$ & $2.164(3)$ & $\mathrm{N} 1-\mathrm{C} 1$ & $1.328(5)$ \\
\hline $\mathrm{Zn} 1-\mathrm{O} 1$ & $2.240(3)$ & $\mathrm{N} 1-\mathrm{C} 5$ & $1.334(5)$ \\
\hline $\mathrm{O} 1-\mathrm{C} 6$ & $1.258(5)$ & $\mathrm{C} 1-\mathrm{C} 2$ & $1.388(6)$ \\
\hline $\mathrm{O} 2-\mathrm{C} 6$ & $1.256(5)$ & $\mathrm{C} 1-\mathrm{C} 6$ & $1.509(5)$ \\
\hline $\mathrm{O} 2-\mathrm{Zn} 1^{\mathrm{iii}}$ & $1.956(3)$ & $\mathrm{C} 2-\mathrm{C} 3$ & $1.403(6)$ \\
\hline $\mathrm{O} 3-\mathrm{C} 7$ & $1.255(5)$ & $\mathrm{C} 2-\mathrm{H} 2$ & 0.9500 \\
\hline $\mathrm{O} 4-\mathrm{C} 7$ & $1.265(5)$ & $\mathrm{C} 3-\mathrm{C} 4$ & $1.398(6)$ \\
\hline $\mathrm{O} 4-\mathrm{Zn} 1^{\text {iv }}$ & $1.987(3)$ & $\mathrm{C} 4-\mathrm{C} 5$ & $1.383(6)$ \\
\hline $\mathrm{O} 5-\mathrm{C} 3$ & $1.344(4)$ & $\mathrm{C} 4-\mathrm{H} 4$ & 0.9500 \\
\hline $\mathrm{O} 5-\mathrm{H} 5 \mathrm{O}$ & $0.82(3)$ & $\mathrm{C} 5-\mathrm{C} 7$ & $1.518(5)$ \\
\hline $\mathrm{O} 2^{\mathrm{i}}-\mathrm{Zn} 1-\mathrm{O} 4^{\mathrm{ii}}$ & $102.10(12)$ & $\mathrm{N} 1-\mathrm{C} 1-\mathrm{C} 6$ & $113.9(3)$ \\
\hline $\mathrm{O} 2^{\mathrm{i}}-\mathrm{Zn} 1-\mathrm{N} 1$ & $135.97(12)$ & $\mathrm{C} 2-\mathrm{C} 1-\mathrm{C} 6$ & $123.8(3)$ \\
\hline $\mathrm{O} 4^{\mathrm{ii}}-\mathrm{Zn} 1-\mathrm{N} 1$ & $121.41(12)$ & $\mathrm{C} 1-\mathrm{C} 2-\mathrm{C} 3$ & $118.0(4)$ \\
\hline $\mathrm{O} 2^{\mathrm{i}}-\mathrm{Zn} 1-\mathrm{O} 3$ & $94.78(12)$ & $\mathrm{C} 1-\mathrm{C} 2-\mathrm{H} 2$ & 121.0 \\
\hline $\mathrm{O} 4^{\mathrm{ii}-} \mathrm{Zn} 1-\mathrm{O} 3$ & $94.93(12)$ & $\mathrm{C} 3-\mathrm{C} 2-\mathrm{H} 2$ & 121.0 \\
\hline $\mathrm{N} 1-\mathrm{Zn} 1-\mathrm{O} 3$ & $76.38(11)$ & $\mathrm{O} 5-\mathrm{C} 3-\mathrm{C} 4$ & $120.4(4)$ \\
\hline $\mathrm{O} 2^{\mathrm{i}}-\mathrm{Zn} 1-\mathrm{O} 1$ & $102.52(12)$ & $\mathrm{O} 5-\mathrm{C} 3-\mathrm{C} 2$ & 120.1 \\
\hline $\mathrm{O} 4^{\mathrm{ii}-} \mathrm{Zn} 1-\mathrm{O} 1$ & $102.68(12)$ & $\mathrm{C} 4-\mathrm{C} 3-\mathrm{C} 2$ & $119.5(3)$ \\
\hline $\mathrm{N} 1-\mathrm{Zn} 1-\mathrm{O} 1$ & $75.85(11)$ & $\mathrm{C} 5-\mathrm{C} 4-\mathrm{C} 3$ & $117.8(4)$ \\
\hline $\mathrm{O} 3-\mathrm{Zn} 1-\mathrm{O} 1$ & $151.96(9)$ & $\mathrm{C} 5-\mathrm{C} 4-\mathrm{H} 4$ & 121.1 \\
\hline $\mathrm{C} 6-\mathrm{O} 1-\mathrm{Zn} 1$ & $112.8(2)$ & $\mathrm{C} 3-\mathrm{C} 4-\mathrm{H} 4$ & 121.1 \\
\hline $\mathrm{C} 6-\mathrm{O} 2-\mathrm{Zn} 1^{\mathrm{iii}}$ & $120.4(3)$ & $\mathrm{N} 1-\mathrm{C} 5-\mathrm{C} 4$ & 122.5 \\
\hline $\mathrm{C} 7-\mathrm{O} 3-\mathrm{Zn} 1$ & $115.0(2)$ & $\mathrm{N} 1-\mathrm{C} 5-\mathrm{C} 7$ & $112.6(3)$ \\
\hline $\mathrm{C} 7-\mathrm{O} 4-\mathrm{Zn} 1^{\mathrm{iv}}$ & $111.0(3)$ & $\mathrm{C} 4-\mathrm{C} 5-\mathrm{C} 7$ & $124.7(4)$ \\
\hline $\mathrm{C} 3-\mathrm{O} 5-\mathrm{H} 5 \mathrm{O}$ & 109 (4) & $\mathrm{O} 2-\mathrm{C} 6-\mathrm{O} 1$ & $126.3(4)$ \\
\hline $\mathrm{H} 7 \mathrm{~A}-\mathrm{O} 7-\mathrm{H} 7 \mathrm{~B}$ & 105.5 & $\mathrm{O} 2-\mathrm{C} 6-\mathrm{C} 1$ & $116.7(3)$ \\
\hline $\mathrm{C} 1-\mathrm{N} 1-\mathrm{C} 5$ & $120.0(3)$ & $\mathrm{O} 1-\mathrm{C} 6-\mathrm{C} 1$ & 117.0 \\
\hline $\mathrm{C} 1-\mathrm{N} 1-\mathrm{Zn} 1$ & $119.4(3)$ & $\mathrm{O} 3-\mathrm{C} 7-\mathrm{O} 4$ & $125.7(4)$ \\
\hline $\mathrm{C} 5-\mathrm{N} 1-\mathrm{Zn} 1$ & $118.9(3)$ & $\mathrm{O} 3-\mathrm{C} 7-\mathrm{C} 5$ & 116.1 \\
\hline $\mathrm{N} 1-\mathrm{C} 1-\mathrm{C} 2$ & $122.1(4)$ & $\mathrm{O} 4-\mathrm{C} 7-\mathrm{C} 5$ & $118.1(3)$ \\
\hline
\end{tabular}

Symmetry codes: (i) $y,-x+2,-z+1$; (ii) $y,-x+1,-z+1$; (iii) $-y+2, x,-z+1$; (iv) $-y+1, x,-z+1$. 
Hydrogen-bond geometry $\left(\AA,{ }^{\circ}\right)$

\begin{tabular}{|c|c|c|c|c|}
\hline$D-\mathrm{H} \cdots A$ & $D-\mathrm{H}$ & $\mathrm{H} \cdots A$ & $D \cdots A$ & $D-\mathrm{H}^{\cdots} \cdots A$ \\
\hline $\mathrm{O} 5-\mathrm{H} 5 \mathrm{O} \cdots \mathrm{O} 7$ & $0.82(3)$ & $1.94(3)$ & $2.765(4)$ & $172(6)$ \\
\hline $\mathrm{O} 6-\mathrm{H} 6 P^{\cdots} \cdots 5^{v}$ & 0.84 & 1.95 & $2.782(4)$ & 174 \\
\hline $\mathrm{O} 7-\mathrm{H} 7 A \cdots \mathrm{O} 1^{\mathrm{vi}}$ & 0.84 & 2.38 & $3.220(4)$ & 177 \\
\hline $\mathrm{O} 7-\mathrm{H} 7 A \cdots \mathrm{O} 2^{\mathrm{vi}}$ & 0.84 & 2.50 & $3.098(3)$ & 129 \\
\hline $\mathrm{O} 7-\mathrm{H} 7 B^{\cdots} \cdots 1^{\text {vii }}$ & 0.84 & 2.38 & $3.220(4)$ & 177 \\
\hline $\mathrm{O} 7-\mathrm{H} 7 B^{\cdots} \cdots \mathrm{O} 2^{\mathrm{vii}}$ & 0.84 & 2.50 & $3.098(3)$ & 129 \\
\hline
\end{tabular}

Symmetry codes: (v) $-x+2,-y+1, z$; (vi) $-x+3 / 2, y-1 / 2,-z+3 / 2$; (vii) $x-1 / 2,-y+3 / 2,-z+3 / 2$.

Triaqua(4-chloropyridine-2,6-dicarboxylato)nickel(II) (5)

\section{Crystal data}

$\left[\mathrm{Ni}\left(\mathrm{C}_{7} \mathrm{H}_{2} \mathrm{ClNO}_{4}\right)\left(\mathrm{H}_{2} \mathrm{O}\right)_{3}\right]$

$M_{r}=312.30$

Tetragonal, $I 4_{1} / a$

$a=9.544(2) \AA$

$c=23.361(5) \AA$

$V=2127.9(11) \AA^{3}$

$Z=8$

$F(000)=1264$

\section{Data collection}

Bruker APEX CCD

diffractometer

Radiation source: microsource

Multilayer optics monochromator

$\omega$ scans

Absorption correction: multi-scan

SADABS (Bruker, 2008)

$T_{\min }=0.468, T_{\max }=0.745$

Refinement

Refinement on $F^{2}$

Least-squares matrix: full

$R\left[F^{2}>2 \sigma\left(F^{2}\right)\right]=0.050$

$w R\left(F^{2}\right)=0.127$

$S=1.14$

1127 reflections

99 parameters

8 restraints

Special details

Geometry. All esds (except the esd in the dihedral angle between two 1.s. planes) are estimated using the full covariance matrix. The cell esds are taken into account individually in the estimation of esds in distances, angles and torsion angles; correlations between esds in cell parameters are only used when they are defined by crystal symmetry. An approximate (isotropic) treatment of cell esds is used for estimating esds involving l.s. planes.
$D_{\mathrm{x}}=1.950 \mathrm{Mg} \mathrm{m}^{-3}$

Mo $K \alpha$ radiation, $\lambda=0.71073 \AA$

Cell parameters from 2927 reflections

$\theta=2.3-26.2^{\circ}$

$\mu=2.10 \mathrm{~mm}^{-1}$

$T=250 \mathrm{~K}$

Rod, green

$0.40 \times 0.25 \times 0.18 \mathrm{~mm}$

12540 measured reflections

1127 independent reflections

935 reflections with $I>2 \sigma(I)$

$R_{\text {int }}=0.092$

$\theta_{\max }=26.8^{\circ}, \theta_{\min }=2.3^{\circ}$

$h=-12 \rightarrow 11$

$k=-12 \rightarrow 12$

$l=-29 \rightarrow 29$

Hydrogen site location: mixed

$\mathrm{H}$ atoms treated by a mixture of independent and constrained refinement

$w=1 /\left[\sigma^{2}\left(F_{\mathrm{o}}{ }^{2}\right)+(0.0337 P)^{2}+17.5732 P\right]$

where $P=\left(F_{\mathrm{o}}^{2}+2 F_{\mathrm{c}}^{2}\right) / 3$

$(\Delta / \sigma)_{\max }<0.001$

$\Delta \rho_{\max }=0.50$ e $\AA^{-3}$

$\Delta \rho_{\min }=-0.51$ e $\AA^{-3}$ 
Fractional atomic coordinates and isotropic or equivalent isotropic displacement parameters $\left(\AA^{2}\right)$

\begin{tabular}{llllll}
\hline & $x$ & $y$ & $z$ & $U_{\text {iss }} * / U_{\text {eq }}$ & Occ. $(<1)$ \\
\hline Ni1 & 0.5000 & 0.2500 & $0.53529(3)$ & $0.0225(3)$ & $0.0661(8)$ \\
C11 & 0.5000 & 0.2500 & $0.80909(7)$ & $0.0294(8)$ & $0.55(8)$ \\
O1 & $0.6275(4)$ & $0.4270(4)$ & $0.55472(12)$ & $0.035(6)$ & $0.45(8)$ \\
O2B & $0.667(4)$ & $0.574(2)$ & $0.6293(4)$ & $0.034(7)$ & $0.037 *$ \\
O2A & $0.733(6)$ & $0.538(4)$ & $0.6258(9)$ & $0.037 *$ \\
O3 & $0.6692(4)$ & $0.1210(4)$ & $0.52847(14)$ & $0.0361(12)$ \\
$\mathrm{H} 3 \mathrm{O}$ & $0.740(3)$ & $0.163(5)$ & $0.523(2)$ & $0.043 *$ & $0.0239(11)$ \\
$\mathrm{H} 3 \mathrm{P}$ & $0.668(5)$ & $0.068(5)$ & $0.5556(17)$ & $0.0296(11)$ \\
O4 & 0.5000 & 0.2500 & $0.4487(2)$ & $0.0363(12)$ \\
$\mathrm{H} 4 \mathrm{O}$ & $0.434(3)$ & $0.229(7)$ & $0.4299(15)$ & $0.044 *$ \\
$\mathrm{~N} 1$ & 0.5000 & 0.2500 & $0.6198(2)$ & $0.0351(16)$ \\
$\mathrm{C} 1$ & $0.5686(6)$ & $0.3496(5)$ & $0.64751(19)$ & $0.0386(13)$ \\
$\mathrm{C} 2$ & $0.5715(6)$ & $0.3546(5)$ & $0.70670(19)$ &
\end{tabular}

Atomic displacement parameters $\left(\AA^{2}\right)$

\begin{tabular}{lllllll}
\hline & $U^{11}$ & $U^{22}$ & $U^{33}$ & $U^{12}$ & $U^{13}$ & $U^{23}$ \\
\hline Ni1 & $0.0320(5)$ & $0.0250(5)$ & $0.0104(4)$ & $0.0007(4)$ & 0.000 & 0.000 \\
C11 & $0.136(2)$ & $0.0509(13)$ & $0.0115(8)$ & $-0.0140(14)$ & 0.000 & 0.000 \\
O1 & $0.043(2)$ & $0.0322(18)$ & $0.0135(14)$ & $-0.0082(15)$ & $-0.0012(13)$ & $0.0011(13)$ \\
O2B & $0.059(12)$ & $0.023(6)$ & $0.021(4)$ & $-0.021(6)$ & $0.000(4)$ & $-0.005(3)$ \\
O2A & $0.075(19)$ & $0.051(9)$ & $0.036(6)$ & $-0.011(13)$ & $-0.013(8)$ & $-0.002(6)$ \\
O3 & $0.036(2)$ & $0.034(2)$ & $0.0229(16)$ & $0.0024(15)$ & $-0.0037(15)$ & $-0.0010(14)$ \\
O4 & $0.048(3)$ & $0.044(3)$ & $0.016(2)$ & $0.006(3)$ & 0.000 & 0.000 \\
N1 & $0.031(3)$ & $0.020(3)$ & $0.021(3)$ & $0.000(2)$ & 0.000 & 0.000 \\
C1 & $0.045(3)$ & $0.028(2)$ & $0.015(2)$ & $0.000(2)$ & $-0.0011(19)$ & $0.0004(18)$ \\
C2 & $0.060(4)$ & $0.033(3)$ & $0.016(2)$ & $-0.008(3)$ & $-0.005(2)$ & $0.0001(19)$ \\
C3 & $0.061(5)$ & $0.030(4)$ & $0.014(3)$ & $-0.001(3)$ & 0.000 & 0.000 \\
C4 & $0.062(4)$ & $0.034(3)$ & $0.020(2)$ & $-0.016(3)$ & $-0.007(2)$ & $0.003(2)$ \\
& & & & & &
\end{tabular}

Geometric parameters $\left(\hat{A},{ }^{o}\right)$

\begin{tabular}{llll}
\hline $\mathrm{Ni} 1-\mathrm{N} 1$ & $1.975(5)$ & $\mathrm{O} 3-\mathrm{H} 3 \mathrm{O}$ & $0.794(19)$ \\
$\mathrm{Ni} 1-\mathrm{O} 4$ & $2.023(5)$ & $\mathrm{O} 3-\mathrm{H} 3 \mathrm{P}$ & $0.809(19)$ \\
$\mathrm{Ni} 1-\mathrm{O} 3^{\mathrm{i}}$ & $2.036(4)$ & $\mathrm{O} 4-\mathrm{H} 4 \mathrm{O}$ & $0.794(18)$ \\
$\mathrm{Ni1}-\mathrm{O} 3$ & $2.036(4)$ & $\mathrm{N} 1-\mathrm{C} 1$ & $1.323(5)$ \\
$\mathrm{Ni1}-\mathrm{O} 1$ & $\mathrm{~N} 1-\mathrm{C} 1^{\mathrm{i}}$ & $1.323(5)$ \\
$\mathrm{Ni1}-\mathrm{O} 1^{\mathrm{i}}$ & $2.131(3)$ & $\mathrm{C} 1-\mathrm{C} 2$ & $1.384(6)$ \\
$\mathrm{C} 11-\mathrm{C} 3$ & $2.131(3)$ & $\mathrm{C} 1-\mathrm{C} 4$ & $1.518(7)$ \\
$\mathrm{O} 1-\mathrm{C} 4$ & $1.717(7)$ & $\mathrm{C} 2-\mathrm{C} 3$ & $1.385(6)$ \\
$\mathrm{O} 2 \mathrm{~B}-\mathrm{C} 4$ & $1.267(6)$ & $\mathrm{C} 2-\mathrm{H} 2$ & 0.9400 \\
$\mathrm{O} 2 \mathrm{~A}-\mathrm{C} 4$ & $1.280(13)$ & $\mathrm{C} 3-\mathrm{C} 2^{\mathrm{i}}$ & $1.385(6)$
\end{tabular}




\begin{tabular}{|c|c|c|c|}
\hline $\mathrm{N} 1-\mathrm{Ni1}-\mathrm{O} 4$ & 180.0 & $\mathrm{Ni} 1-\mathrm{O} 4-\mathrm{H} 4 \mathrm{O}$ & $124(3)$ \\
\hline $\mathrm{N} 1-\mathrm{Ni} 1-\mathrm{O}^{\mathrm{i}}$ & $94.48(9)$ & $\mathrm{C} 1-\mathrm{N} 1-\mathrm{C}^{\mathrm{i}}$ & $121.5(6)$ \\
\hline $\mathrm{O} 4-\mathrm{Ni} 1-\mathrm{O}^{\mathrm{i}}$ & $85.52(9)$ & $\mathrm{C} 1-\mathrm{N} 1-\mathrm{Ni} 1$ & $119.3(3)$ \\
\hline $\mathrm{N} 1-\mathrm{Ni} 1-\mathrm{O} 3$ & $94.48(9)$ & $\mathrm{C} 1{ }^{\mathrm{i}}-\mathrm{N} 1-\mathrm{Ni} 1$ & $119.3(3)$ \\
\hline $\mathrm{O} 4-\mathrm{Ni} 1-\mathrm{O} 3$ & $85.52(9)$ & $\mathrm{N} 1-\mathrm{C} 1-\mathrm{C} 2$ & $121.5(5)$ \\
\hline $\mathrm{O} 3^{\mathrm{i}}-\mathrm{Ni} 1-\mathrm{O} 3$ & $171.03(19)$ & $\mathrm{N} 1-\mathrm{C} 1-\mathrm{C} 4$ & $112.8(4)$ \\
\hline $\mathrm{N} 1-\mathrm{Ni1}-\mathrm{O} 1$ & $77.70(8)$ & $\mathrm{C} 2-\mathrm{C} 1-\mathrm{C} 4$ & $125.6(5)$ \\
\hline $\mathrm{O} 4-\mathrm{Ni} 1-\mathrm{O} 1$ & $102.30(8)$ & $\mathrm{C} 1-\mathrm{C} 2-\mathrm{C} 3$ & $116.9(5)$ \\
\hline 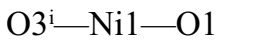 & $89.43(14)$ & $\mathrm{C} 1-\mathrm{C} 2-\mathrm{H} 2$ & 121.6 \\
\hline $\mathrm{O} 3-\mathrm{Ni1}-\mathrm{O} 1$ & $92.48(14)$ & $\mathrm{C} 3-\mathrm{C} 2-\mathrm{H} 2$ & 121.6 \\
\hline $\mathrm{N} 1-\mathrm{Ni} 1-\mathrm{O} 1^{\mathrm{i}}$ & $77.70(8)$ & $\mathrm{C} 2 \mathrm{i}-\mathrm{C} 3-\mathrm{C} 2$ & $121.7(6)$ \\
\hline $\mathrm{O} 4-\mathrm{Ni} 1-\mathrm{O} 1^{\mathrm{i}}$ & $102.30(8)$ & $\mathrm{C} 22^{\mathrm{i}}-\mathrm{C} 3-\mathrm{C} 11$ & $119.2(3)$ \\
\hline $\mathrm{O} 3^{\mathrm{i}}-\mathrm{Ni1}-\mathrm{O} 1^{\mathrm{i}}$ & $92.48(14)$ & $\mathrm{C} 2-\mathrm{C} 3-\mathrm{Cl} 1$ & $119.2(3)$ \\
\hline $\mathrm{O} 3-\mathrm{Ni} 1-\mathrm{O} 1^{\mathrm{i}}$ & $89.43(14)$ & $\mathrm{O} 1-\mathrm{C} 4-\mathrm{O} 2 \mathrm{~B}$ & $126.1(7)$ \\
\hline $\mathrm{O} 1-\mathrm{Ni} 1-\mathrm{O} 1^{\mathrm{i}}$ & $155.40(16)$ & $\mathrm{O} 1-\mathrm{C} 4-\mathrm{O} 2 \mathrm{~A}$ & $120.3(15)$ \\
\hline $\mathrm{C} 4-\mathrm{O} 1-\mathrm{Ni1}$ & $114.5(3)$ & $\mathrm{O} 1-\mathrm{C} 4-\mathrm{C} 1$ & $115.4(4)$ \\
\hline $\mathrm{Ni1}-\mathrm{O} 3-\mathrm{H} 3 \mathrm{O}$ & $113(4)$ & $\mathrm{O} 2 \mathrm{~B}-\mathrm{C} 4-\mathrm{C} 1$ & $116.3(7)$ \\
\hline $\mathrm{Ni1}-\mathrm{O} 3-\mathrm{H} 3 \mathrm{P}$ & $108(4)$ & $\mathrm{O} 2 \mathrm{~A}-\mathrm{C} 4-\mathrm{C} 1$ & $120.7(8)$ \\
\hline $\mathrm{H} 3 \mathrm{O}-\mathrm{O} 3-\mathrm{H} 3 \mathrm{P}$ & $117(4)$ & & \\
\hline
\end{tabular}

Symmetry code: (i) $-x+1,-y+1 / 2, z$.

Hydrogen-bond geometry $\left(\AA,{ }^{\circ}\right)$

\begin{tabular}{lllll}
\hline$D-\mathrm{H} \cdots A$ & $D-\mathrm{H}$ & $\mathrm{H} \cdots A$ & $D \cdots A$ & $D-\mathrm{H} \cdots A$ \\
\hline $\mathrm{O} 3-\mathrm{H} 3 P \cdots \mathrm{O} 2 B^{\mathrm{ii}}$ & $0.81(2)$ & $2.10(3)$ & $2.90(3)$ & $174(5)$ \\
$\mathrm{O} 3-\mathrm{H} 3 P \cdots \mathrm{O} 2 A^{\text {ii }}$ & $0.81(2)$ & $1.85(3)$ & $2.628(18)$ & $162(6)$ \\
$\mathrm{O} 3-\mathrm{H} 3 O \cdots \mathrm{Cl} 1^{\mathrm{iii}}$ & $0.79(2)$ & $2.75(3)$ & $3.464(4)$ & $150(5)$ \\
$\mathrm{O} 4-\mathrm{H} 4 O \cdots \mathrm{O} 2 B^{\mathrm{iv}}$ & $0.79(2)$ & $2.53(6)$ & $2.95(3)$ & $115(5)$ \\
$\mathrm{O} 4-\mathrm{H} 4 O \cdots \mathrm{O} 2 B^{\mathrm{v}}$ & $0.79(2)$ & $2.11(5)$ & $2.83(3)$ & $151(6)$ \\
\hline
\end{tabular}

Symmetry codes: (ii) $-y+5 / 4, x-3 / 4,-z+5 / 4$; (iii) $-y+5 / 4, x-1 / 4, z-1 / 4$; (iv) $-x+1,-y+1,-z+1$; (v) $y-1 / 4,-x+3 / 4, z-1 / 4$.

Triaqua(4-hydroxypyridine-2,6-dicarboxylato)nickel(II) 1.7-hydrate (6)

Crystal data

$\left[\mathrm{Ni}\left(\mathrm{C}_{7} \mathrm{H}_{3} \mathrm{NO}_{5}\right)\left(\mathrm{H}_{2} \mathrm{O}\right)_{3}\right] \cdot 1.7 \mathrm{H}_{2} \mathrm{O}$

$M_{r}=324.49$

Monoclinic, $C 2 / c$

$a=14.7249(11) \AA$

$b=6.8538(5) \AA$

$c=22.3510(16) \AA$

$\beta=90.355(1)^{\circ}$

$V=2255.7(3) \AA^{3}$

$Z=8$

$F(000)=1336$

$D_{\mathrm{x}}=1.911 \mathrm{Mg} \mathrm{m}^{-3}$

Mo $K \alpha$ radiation, $\lambda=0.71073 \AA$

Cell parameters from 5539 reflections

$\theta=2.8-30.1^{\circ}$

$\mu=1.77 \mathrm{~mm}^{-1}$

$T=100 \mathrm{~K}$

Block, brown

$0.33 \times 0.32 \times 0.12 \mathrm{~mm}$

Data collection

Bruker APEX CCD

diffractometer

Multilayer optics monochromator

$\omega$ scans

Radiation source: microsource 


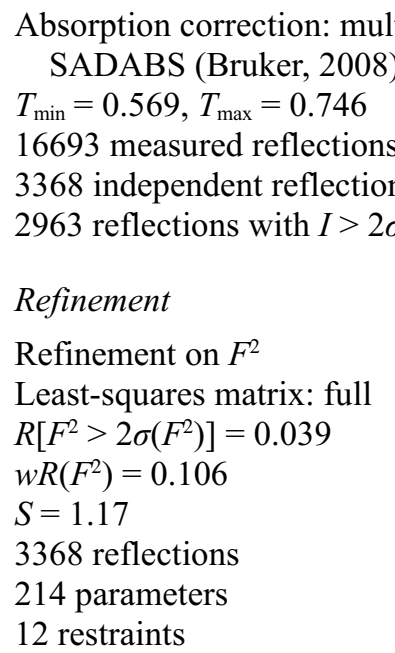

$$
\begin{aligned}
& R_{\text {int }}=0.027 \\
& \theta_{\max }=31.0^{\circ}, \theta_{\text {min }}=2.8^{\circ} \\
& h=-21 \rightarrow 21 \\
& k=-9 \rightarrow 9 \\
& l=-31 \rightarrow 30
\end{aligned}
$$

Hydrogen site location: mixed

$\mathrm{H}$ atoms treated by a mixture of independent and constrained refinement

$w=1 /\left[\sigma^{2}\left(F_{\mathrm{o}}^{2}\right)+(0.0471 P)^{2}+5.9483 P\right]$ where $P=\left(F_{\mathrm{o}}^{2}+2 F_{\mathrm{c}}^{2}\right) / 3$

$(\Delta / \sigma)_{\max }<0.001$

$\Delta \rho_{\max }=0.79$ e $\AA^{-3}$

$\Delta \rho_{\min }=-0.52$ e $\AA^{-3}$

Special details

Geometry. All esds (except the esd in the dihedral angle between two 1.s. planes) are estimated using the full covariance

\begin{tabular}{|c|c|c|c|c|c|}
\hline & $x$ & $y$ & $z$ & $U_{\text {iso }} * / U_{\text {eq }}$ & Occ. $(<1)$ \\
\hline Nil & $0.48005(2)$ & $0.75027(4)$ & $0.63778(2)$ & $0.01414(10)$ & \\
\hline $\mathrm{O} 1$ & $0.52712(10)$ & $0.7082(2)$ & $0.54625(7)$ & $0.0134(3)$ & \\
\hline $\mathrm{O} 2$ & $0.48457(11)$ & $0.7612(2)$ & $0.45125(7)$ & 0.0143 & \\
\hline $\mathrm{O} 3$ & $0.38945(11)$ & $0.8469(2)$ & $0.70495(7)$ & $0.0181(3)$ & \\
\hline $\mathrm{O} 4 \mathrm{~A}$ & $0.27374(15)$ & $1.0577(4)$ & $0.71517(8)$ & $0.0234(7)$ & $0.904(9)$ \\
\hline O4B & $0.2459(12)$ & $0.959(3)$ & $0.7121(7)$ & $0.014(5)^{*}$ & $0.096(9)$ \\
\hline $\mathrm{O} 5$ & $0.17015(10)$ & $1.0753(2)$ & $0.48993(7)$ & $0.0137(3)$ & \\
\hline $\mathrm{H} 5 \mathrm{O}$ & 0.1287 & 1.1189 & 0.5118 & $0.021^{*}$ & \\
\hline O6 & $0.42492(12)$ & $0.4707(2)$ & $0.63491(7)$ & $0.0172(3)$ & \\
\hline $\mathrm{H} 6 \mathrm{O}$ & $0.441(3)$ & $0.418(5)$ & $0.6044(12)$ & $0.042(10)^{*}$ & \\
\hline H6P & $0.3683(13)$ & $0.475(7)$ & $0.639(2)$ & $0.057(13)^{*}$ & \\
\hline O7 & $0.57597(12)$ & $0.6389(3)$ & $0.69216(7)$ & $0.0204(3)$ & \\
\hline $\mathrm{H} 7 \mathrm{P}$ & $0.593(3)$ & $0.707(5)$ & $0.7192(13)$ & $0.039(10)^{*}$ & \\
\hline $\mathrm{H} 7 \mathrm{O}$ & $0.573(3)$ & $0.527(3)$ & 0.7046 (19) & $0.055(13)^{*}$ & \\
\hline O8 & $0.55505(12)$ & $1.0078(3)$ & $0.64271(8)$ & $0.0232(4)$ & \\
\hline H8P & $0.6094(13)$ & $0.990(6)$ & $0.6466(18)$ & $0.043(11)^{*}$ & \\
\hline $\mathrm{H} 8 \mathrm{O}$ & $0.548(2)$ & $1.071(4)$ & $0.6119(11)$ & $0.029(9)^{*}$ & \\
\hline O9 & $0.25952(14)$ & 0.9505 & $0.83233(8)$ & $0.0324(5)$ & \\
\hline $\mathrm{H} 9 \mathrm{O}$ & 0.2616 & 0.8316 & 0.8228 & $0.039 *$ & \\
\hline H9P & 0.2564 & 1.0091 & 0.7994 & $0.039 *$ & \\
\hline $\mathrm{O} 10$ & 0.5000 & $0.2818(8)$ & 0.7500 & $0.0378(14)$ & $0.602(7)$ \\
\hline O11 & $0.5818(4)$ & $0.2770(7)$ & $0.7227(2)$ & $0.0269(15)$ & $0.398(7)$ \\
\hline $\mathrm{H} 11 \mathrm{O}$ & $0.624(5)$ & $0.268(12)$ & $0.747(3)$ & $0.032 *$ & $0.398(7)$ \\
\hline $\mathrm{H} 10 \mathrm{O}$ & $0.536(4)$ & $0.210(6)$ & $0.731(4)$ & $0.20(5)^{*}$ & \\
\hline
\end{tabular}
matrix. The cell esds are taken into account individually in the estimation of esds in distances, angles and torsion angles; correlations between esds in cell parameters are only used when they are defined by crystal symmetry. An approximate (isotropic) treatment of cell esds is used for estimating esds involving 1.s. planes.

Fractional atomic coordinates and isotropic or equivalent isotropic displacement parameters $\left(\AA^{2}\right)$ 


$\begin{array}{lllll}\mathrm{N} 1 & 0.38314(12) & 0.8706(3) & 0.58926(8) & 0.0117(3) \\ \mathrm{C} 1 & 0.38576(13) & 0.8646(3) & 0.52962(9) & 0.0097(3) \\ \mathrm{C} 2 & 0.31536(13) & 0.9363(3) & 0.49499(9) & 0.0103(3) \\ \mathrm{H} 2 & 0.3184 & 0.9330 & 0.4526 & 0.012^{*} \\ \mathrm{C} 3 & 0.23924(13) & 1.0142(3) & 0.52399(9) & 0.0112(4) \\ \mathrm{C} 4 & 0.23817(14) & 1.0234(3) & 0.58684(9) & 0.0130(4) \\ \mathrm{H} 4 & 0.1882 & 1.0784 & 0.6075 & 0.016^{*} \\ \mathrm{C} 5 & 0.31234(14) & 0.9496(3) & 0.61747(9) & 0.0129(4) \\ \mathrm{C} 6 & 0.47189(14) & 0.7704(3) & 0.50617(9) & 0.0109(4) \\ \mathrm{C} 7 & 0.32457(16) & 0.9490(4) & 0.68510(10) & 0.0194(4)\end{array}$

Atomic displacement parameters $\left(\AA^{2}\right)$

\begin{tabular}{lllllll}
\hline & $U^{11}$ & $U^{22}$ & $U^{33}$ & $U^{12}$ & $U^{13}$ & $U^{23}$ \\
\hline Ni1 & $0.01316(15)$ & $0.01744(16)$ & $0.01178(15)$ & $0.00301(10)$ & $-0.00192(10)$ & $-0.00028(10)$ \\
O1 & $0.0100(7)$ & $0.0168(7)$ & $0.0133(7)$ & $0.0032(5)$ & $-0.0016(5)$ & $0.0005(5)$ \\
O2 & $0.0129(7)$ & $0.0168(7)$ & $0.0133(7)$ & $0.0034(5)$ & $0.0022(5)$ & $0.0000(5)$ \\
O3 & $0.0188(8)$ & $0.0238(8)$ & $0.0115(7)$ & $0.0072(6)$ & $-0.0021(6)$ & $-0.0004(6)$ \\
O4A & $0.0238(11)$ & $0.0332(15)$ & $0.0132(9)$ & $0.0120(10)$ & $0.0010(7)$ & $-0.0036(8)$ \\
O5 & $0.0087(6)$ & $0.0180(7)$ & $0.0143(7)$ & $0.0050(5)$ & $-0.0015(5)$ & $-0.0006(6)$ \\
O6 & $0.0181(8)$ & $0.0205(8)$ & $0.0130(7)$ & $0.0016(6)$ & $0.0017(6)$ & $-0.0019(6)$ \\
O7 & $0.0173(8)$ & $0.0301(9)$ & $0.0139(7)$ & $0.0098(7)$ & $-0.0032(6)$ & $-0.0038(7)$ \\
O8 & $0.0193(9)$ & $0.0253(9)$ & $0.0248(9)$ & $-0.0030(7)$ & $-0.0096(7)$ & $0.0069(7)$ \\
O9 & $0.0327(10)$ & $0.0447(12)$ & $0.0198(8)$ & $-0.0085(9)$ & $-0.0005(7)$ & $0.0067(8)$ \\
O10 & $0.056(4)$ & $0.031(3)$ & $0.026(2)$ & 0.000 & $-0.007(2)$ & 0.000 \\
O11 & $0.034(3)$ & $0.019(2)$ & $0.028(3)$ & $0.0041(19)$ & $-0.006(2)$ & $0.0017(17)$ \\
N1 & $0.0108(8)$ & $0.0135(8)$ & $0.0108(7)$ & $0.0011(6)$ & $-0.0002(6)$ & $0.0007(6)$ \\
C1 & $0.0068(8)$ & $0.0108(8)$ & $0.0115(8)$ & $-0.0001(6)$ & $0.0001(6)$ & $-0.0006(7)$ \\
C2 & $0.0094(8)$ & $0.0109(8)$ & $0.0106(8)$ & $0.0005(7)$ & $-0.0008(6)$ & $-0.0001(7)$ \\
C3 & $0.0083(8)$ & $0.0109(8)$ & $0.0142(9)$ & $-0.0003(7)$ & $-0.0013(7)$ & $0.0004(7)$ \\
C4 & $0.0097(9)$ & $0.0151(9)$ & $0.0142(9)$ & $0.0030(7)$ & $0.0017(7)$ & $0.0006(7)$ \\
C5 & $0.0120(9)$ & $0.0155(9)$ & $0.0113(8)$ & $0.0027(7)$ & $0.0020(7)$ & $-0.0007(7)$ \\
C6 & $0.0097(8)$ & $0.0098(8)$ & $0.0131(9)$ & $0.0000(7)$ & $0.0008(7)$ & $-0.0006(7)$ \\
C7 & $0.0201(11)$ & $0.0259(11)$ & $0.0121(9)$ & $0.0068(9)$ & $0.0011(8)$ & $0.0001(8)$ \\
& & & & & & \\
\hline
\end{tabular}

Geometric parameters $\left(\AA,{ }^{\circ}\right)$

\begin{tabular}{llll}
\hline Ni1-N1 & $1.9681(17)$ & O8- $\mathrm{H} 8 \mathrm{P}$ & $0.814(19)$ \\
$\mathrm{Ni1}-\mathrm{O} 7$ & $2.0082(17)$ & $\mathrm{O} 8-\mathrm{H} 8 \mathrm{O}$ & $0.820(18)$ \\
$\mathrm{Ni1}-\mathrm{O} 6$ & $2.0816(18)$ & $\mathrm{O}-\mathrm{H} 9 \mathrm{O}$ & 0.8433 \\
$\mathrm{Ni1}-\mathrm{O} 8$ & $2.0848(19)$ & $\mathrm{O}-\mathrm{H} 9 \mathrm{P}$ & 0.8400 \\
$\mathrm{Ni1}-\mathrm{O} 3$ & $2.1205(16)$ & $\mathrm{O} 10-\mathrm{H} 10 \mathrm{O}$ & $0.84(2)$ \\
$\mathrm{Ni1}-\mathrm{O} 1$ & $2.1833(15)$ & $\mathrm{O} 11-\mathrm{H} 11 \mathrm{O}$ & $0.83(2)$ \\
$\mathrm{O} 1-\mathrm{C} 6$ & $1.279(3)$ & $\mathrm{O} 11-\mathrm{H} 10 \mathrm{O}$ & $0.84(2)$ \\
$\mathrm{O} 2-\mathrm{C} 6$ & $1.244(3)$ & $\mathrm{N} 1-\mathrm{C} 1$ & $1.335(2)$ \\
$\mathrm{O} 3-\mathrm{C} 7$ & $1.262(3)$ & $\mathrm{N} 1-\mathrm{C} 5$ & $1.336(3)$ \\
$\mathrm{O} 4 \mathrm{~A}-\mathrm{C} 7$ & $1.254(3)$ & $\mathrm{C} 1-\mathrm{C} 2$ & $1.380(3)$ \\
O4B-C7 & $1.311(17)$ & $\mathrm{C} 1-\mathrm{C} 6$ & $1.519(3)$
\end{tabular}




\begin{tabular}{|c|c|c|c|}
\hline $\mathrm{O} 5-\mathrm{C} 3$ & $1.334(2)$ & $\mathrm{C} 2-\mathrm{C} 3$ & $1.404(3)$ \\
\hline $\mathrm{O} 5-\mathrm{H} 5 \mathrm{O}$ & 0.8400 & $\mathrm{C} 2-\mathrm{H} 2$ & 0.9500 \\
\hline $\mathrm{O} 6-\mathrm{H} 6 \mathrm{O}$ & $0.808(18)$ & $\mathrm{C} 3-\mathrm{C} 4$ & $1.406(3)$ \\
\hline O6-H6P & $0.841(19)$ & $\mathrm{C} 4-\mathrm{C} 5$ & $1.381(3)$ \\
\hline O7-H7P & 0.805 (19) & $\mathrm{C} 4-\mathrm{H} 4$ & 0.9500 \\
\hline $\mathrm{O} 7-\mathrm{H} 7 \mathrm{O}$ & $0.816(19)$ & $\mathrm{C} 5-\mathrm{C} 7$ & $1.521(3)$ \\
\hline $\mathrm{N} 1-\mathrm{Ni1}-\mathrm{O} 7$ & $175.97(7)$ & $\mathrm{H} 11 \mathrm{O}-\mathrm{O} 11-\mathrm{H} 10 \mathrm{O}$ & $115(10)$ \\
\hline $\mathrm{N} 1-\mathrm{Ni1}-\mathrm{O} 6$ & $95.02(7)$ & $\mathrm{C} 1-\mathrm{N} 1-\mathrm{C} 5$ & $120.76(17$ \\
\hline $\mathrm{O} 7-\mathrm{Ni1}-\mathrm{O} 6$ & $86.66(7)$ & $\mathrm{C} 1-\mathrm{N} 1-\mathrm{Ni} 1$ & $120.80(13$ \\
\hline $\mathrm{N} 1-\mathrm{Ni1}-\mathrm{O} 8$ & $93.23(7)$ & $\mathrm{C} 5-\mathrm{N} 1-\mathrm{Ni} 1$ & $118.35(14$ \\
\hline $\mathrm{O} 7-\mathrm{Ni} 1-\mathrm{O} 8$ & $85.38(8)$ & $\mathrm{N} 1-\mathrm{C} 1-\mathrm{C} 2$ & $121.52(18$ \\
\hline $\mathrm{O} 6-\mathrm{Ni1}-\mathrm{O} 8$ & $170.86(7)$ & $\mathrm{N} 1-\mathrm{C} 1-\mathrm{C} 6$ & $112.78(17)$ \\
\hline $\mathrm{N} 1-\mathrm{Ni1}-\mathrm{O} 3$ & $78.58(7)$ & $\mathrm{C} 2-\mathrm{C} 1-\mathrm{C} 6$ & $125.70(18$ \\
\hline $\mathrm{O} 7-\mathrm{Ni} 1-\mathrm{O} 3$ & $97.67(6)$ & $\mathrm{C} 1-\mathrm{C} 2-\mathrm{C} 3$ & $118.41(18$ \\
\hline $\mathrm{O} 6-\mathrm{Ni} 1-\mathrm{O} 3$ & $93.58(7)$ & $\mathrm{C} 1-\mathrm{C} 2-\mathrm{H} 2$ & 120.8 \\
\hline $\mathrm{O} 8-\mathrm{Ni} 1-\mathrm{O} 3$ & $91.91(7)$ & $\mathrm{C} 3-\mathrm{C} 2-\mathrm{H} 2$ & 120.8 \\
\hline $\mathrm{N} 1-\mathrm{Ni1}-\mathrm{O} 1$ & $76.84(6)$ & $\mathrm{O} 5-\mathrm{C} 3-\mathrm{C} 2$ & $117.66(18)$ \\
\hline $\mathrm{O} 7-\mathrm{Ni1}-\mathrm{O} 1$ & $106.90(6)$ & $\mathrm{O} 5-\mathrm{C} 3-\mathrm{C} 4$ & $122.86(18$ \\
\hline $\mathrm{O} 6-\mathrm{Ni} 1-\mathrm{O} 1$ & $88.60(6)$ & $\mathrm{C} 2-\mathrm{C} 3-\mathrm{C} 4$ & $119.47(18$ \\
\hline $\mathrm{O} 8-\mathrm{Ni1}-\mathrm{O} 1$ & $89.44(7)$ & $\mathrm{C} 5-\mathrm{C} 4-\mathrm{C} 3$ & $117.72(18)$ \\
\hline $\mathrm{O} 3-\mathrm{Ni} 1-\mathrm{O} 1$ & $155.42(6)$ & $\mathrm{C} 5-\mathrm{C} 4-\mathrm{H} 4$ & 121.1 \\
\hline $\mathrm{C} 6-\mathrm{O} 1-\mathrm{Ni} 1$ & $114.09(13)$ & $\mathrm{C} 3-\mathrm{C} 4-\mathrm{H} 4$ & 121.1 \\
\hline $\mathrm{C} 7-\mathrm{O} 3-\mathrm{Ni} 1$ & $113.73(14)$ & $\mathrm{N} 1-\mathrm{C} 5-\mathrm{C} 4$ & $122.08(18$ \\
\hline $\mathrm{C} 3-\mathrm{O} 5-\mathrm{H} 5 \mathrm{O}$ & 109.5 & $\mathrm{~N} 1-\mathrm{C} 5-\mathrm{C} 7$ & $112.32(18$ \\
\hline $\mathrm{Ni1}-\mathrm{O} 6-\mathrm{H} 6 \mathrm{O}$ & $109(3)$ & $\mathrm{C} 4-\mathrm{C} 5-\mathrm{C} 7$ & $125.59(18$ \\
\hline $\mathrm{Ni1}-\mathrm{O} 6-\mathrm{H} 6 \mathrm{P}$ & $111(3)$ & $\mathrm{O} 2-\mathrm{C} 6-\mathrm{O} 1$ & $125.13(19$ \\
\hline $\mathrm{H} 6 \mathrm{O}-\mathrm{O} 6-\mathrm{H} 6 \mathrm{P}$ & $114(4)$ & $\mathrm{O} 2-\mathrm{C} 6-\mathrm{C} 1$ & $119.50(18$ \\
\hline $\mathrm{Ni1}-\mathrm{O} 7-\mathrm{H} 7 \mathrm{P}$ & $117(3)$ & $\mathrm{O} 1-\mathrm{C} 6-\mathrm{C} 1$ & $115.36(17)$ \\
\hline $\mathrm{Ni1}-\mathrm{O} 7-\mathrm{H} 7 \mathrm{O}$ & $122(3)$ & $\mathrm{O} 4 \mathrm{~A}-\mathrm{C} 7-\mathrm{O} 3$ & $126.4(2)$ \\
\hline $\mathrm{H} 7 \mathrm{P}-\mathrm{O} 7-\mathrm{H} 7 \mathrm{O}$ & $108(4)$ & $\mathrm{O} 3-\mathrm{C} 7-\mathrm{O} 4 \mathrm{~B}$ & $122.4(8)$ \\
\hline $\mathrm{Ni1}-\mathrm{O} 8-\mathrm{H} 8 \mathrm{P}$ & $113(3)$ & $\mathrm{O} 4 \mathrm{~A}-\mathrm{C} 7-\mathrm{C} 5$ & $117.6(2)$ \\
\hline $\mathrm{Ni} 1-\mathrm{O} 8-\mathrm{H} 8 \mathrm{O}$ & $110(2)$ & $\mathrm{O} 3-\mathrm{C} 7-\mathrm{C} 5$ & $115.80(19)$ \\
\hline $\mathrm{H} 8 \mathrm{P}-\mathrm{O} 8-\mathrm{H} 8 \mathrm{O}$ & $107(4)$ & $\mathrm{O} 4 \mathrm{~B}-\mathrm{C} 7-\mathrm{C} 5$ & $111.0(8)$ \\
\hline $\mathrm{H} 9 \mathrm{O}-\mathrm{O} 9-\mathrm{H} 9 \mathrm{P}$ & 104.0 & & \\
\hline
\end{tabular}

Hydrogen-bond geometry $\left(\AA,{ }^{\circ}\right)$

\begin{tabular}{|c|c|c|c|c|}
\hline$D-\mathrm{H} \cdots A$ & $D-\mathrm{H}$ & $\mathrm{H} \cdots A$ & $D \cdots A$ & $D-\mathrm{H} \cdots A$ \\
\hline $\mathrm{O} 5-\mathrm{H} 5 O \cdots \mathrm{O} 1^{\mathrm{i}}$ & 0.84 & 1.79 & $2.624(2)$ & 169 \\
\hline $\mathrm{O} 6-\mathrm{H} 6 O^{\cdots} \mathrm{O} 2^{\mathrm{ii}}$ & $0.81(2)$ & $2.07(2)$ & $2.836(2)$ & $158(4)$ \\
\hline $\mathrm{O} 6-\mathrm{H} 6 O \cdots \mathrm{O} 5^{\mathrm{iii}}$ & $0.81(2)$ & $2.66(4)$ & $3.130(2)$ & $119(3)$ \\
\hline $\mathrm{O} 6-\mathrm{H} 6 P^{\cdots \cdots} \mathrm{O}^{\mathrm{iv}}$ & $0.84(2)$ & $2.00(2)$ & $2.821(3)$ & $167(4)$ \\
\hline $\mathrm{O} 7-\mathrm{H} 7 P^{\cdots} \mathrm{O}^{v}$ & $0.81(2)$ & $1.96(2)$ & $2.751(2)$ & $166(4)$ \\
\hline $\mathrm{O} 7-\mathrm{H} 7 O^{\cdots} \mathrm{O} 10$ & $0.82(2)$ & $2.24(3)$ & $2.989(5)$ & $152(4)$ \\
\hline $\mathrm{O} 7-\mathrm{H} 7 O^{\cdots} \mathrm{O} 11$ & $0.82(2)$ & $1.77(2)$ & $2.574(5)$ & $170(5)$ \\
\hline $\mathrm{O} 8-\mathrm{H} 8 P^{\cdots}{ }^{\cdots} 9^{v}$ & $0.81(2)$ & $2.00(2)$ & $2.811(3)$ & $173(4)$ \\
\hline $\mathrm{O} 8-\mathrm{H} 80 \cdots \mathrm{O} 2^{\mathrm{vi}}$ & $0.82(2)$ & $1.88(2)$ & $2.691(2)$ & $170(3)$ \\
\hline
\end{tabular}


supporting information

$\begin{array}{lllll}\mathrm{O} 9-\mathrm{H} 9 O \cdots \mathrm{O} 4 A^{\mathrm{iv}} & 0.84 & 2.12 & 2.934(3) & 161 \\ \mathrm{O} 9-\mathrm{H} 9 O \cdots \mathrm{O} 4 B^{\mathrm{iv}} & 0.84 & 2.67 & 3.51(2) & 175 \\ \mathrm{O} 9-\mathrm{H} 9 P \cdots \mathrm{O} 4 A & 0.84 & 1.93 & 2.729(3) & 159 \\ \mathrm{O}-\mathrm{H} 9 P \cdots \mathrm{O} 4 B & 0.84 & 1.98 & 2.693(17) & 142 \\ \mathrm{C} 4-\mathrm{H} 4 \cdots \mathrm{O} 7^{\mathrm{i}} & 0.95 & 2.55 & 3.456(3) & 159\end{array}$

Symmetry codes: (i) $x-1 / 2, y+1 / 2, z$; (ii) $-x+1,-y+1,-z+1$; (iii) $-x+1 / 2,-y+3 / 2,-z+1$; (iv) $-x+1 / 2, y-1 / 2,-z+3 / 2$; (v) $-x+1, y,-z+3 / 2$; (vi) $-x+1,-y+2$, $-z+1$. 